MARLOS CORTEZ SAMPAIO

\title{
EFEITOS DA MT-I, UMA FOSFOLIPASE A ISOLADA DO \\ VENENO DE Bothrops asper EM MASTÓCITOS: ATIVAÇÃO E SINALIZAÇÃO INTRACELULAR ENVOLVIDA NA DESGRANULAÇÃO
}

Tese apresentada ao Programa de Pós-Graduação em Imunologia do Instituto de Ciências Biomédicas da Universidade de São Paulo, para obtenção do Título de Doutor em Ciências. 


\section{EFEITOS DA MT-I, UMA FOSFOLIPASE A ASOLADA DO \\ VENENO DE Bothrops asper EM MASTÓCITOS: ATIVAÇÃO E SINALIZAÇÃO INTRACELULAR ENVOLVIDA NA DESGRANULAÇÃO}

Tese apresentada ao Programa de Pós-Graduação em Imunologia do Instituto de Ciências Biomédicas da Universidade de São Paulo, para obtenção do Título de Doutor em Ciências.

Área de concentração: Imunologia

Orientador: Dra. Catarina de Fátima Pereira Teixeira

Versão corrigida. A versão original eletrônica encontra-se disponível tanto na Biblioteca do ICB quanto na Biblioteca Digital de Teses e Dissertações da USP (BDTD). 
DADOS DE CATALOGAÇẢO NA PUBLICAÇĀO (CIP)

Serviço de Biblioteca e Informação Biomédica do

Instituto de Ciências Biomédicas da Universidade de São Paulo

reproduçäo näo autorizada pelo autor

\section{Sampaio, Marlos Cortez.}

Efeitos da MT-I, uma fosfolipase $A_{2}$ isolada do veneno de Bothrops asper em mastócitos: ativação e sinalização intracelular envolvida na desgranulação / Marlos Cortez Sampaio. -- São Paulo, 2015.

Orientador: Profa. Dra.Catarina de Fátima Pereira Teixeira.

Tese (Doutorado) - Universidade de São Paulo. Instituto de Ciências Biomédicas. Departamento de Imunologia. Área de concentração: Imunologia. Linha de pesquisa: Efeitos de fosfolipases $A_{2}$ de serpentes em mastócitos.

Versão do titulo para o inglès: Effects of MT-l a phospholipase $A_{2}$ isolated from Bothrops asper venom, on mast cells: activation and intracellular signaling involved in degranulation.

1. Fosfolipase $A_{2} \quad 2$. Veneno de serpente 3. Mastócitos 4. Desgranulação 5. Ativação ativação e sinalização intracelular envolvida na desgranulação I. Teixeira, Profa. Dra. Catarina de Fátima Pereira II. Universidade de São Paulo. Instituto de Ciências Biomédicas. Programa de Pós-Graduaçäo em Imunologia III. Título. 
Candidato(a): $\quad$ Marlos Cortez Sampaio.

Título da Tese: $\quad$ Efeitos da MT-I, uma fosfolipase $A_{2}$ isolada do veneno de Bothrops asper em mastócitos: ativação e sinalização intracelular envolvida na desgranulação.

Orientador(a):

Profa. Dra. Catarina de Fátima Pereira Teixeira.

A Comissão Julgadora dos trabalhos de Defesa da Tese de Doutorado, em sessão pública realizada a considerou
( ) Aprovado(a)
( ) Reprovado(a)

\begin{tabular}{|c|c|}
\hline Examinador(a): & Assinatura: \\
\hline & 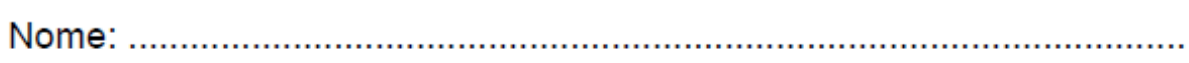 \\
\hline & Instituição: ....... \\
\hline Examinador(a): & Assinatura: .............................. \\
\hline & Nome: ........................ \\
\hline & Instituição: ........ \\
\hline Examinador(a): & Assinatura: ...................... \\
\hline & Nome: ............................ \\
\hline & Instituição: ........ \\
\hline Examinador(a): & 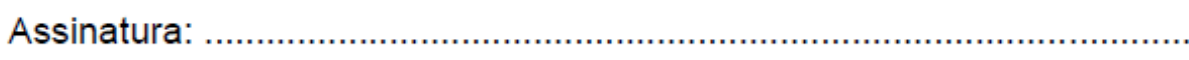 \\
\hline & Nome: \\
\hline & Instituição: \\
\hline Presidente: & Assinatura: ....................... \\
\hline & Nome: \\
\hline & 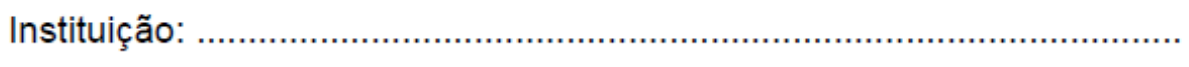 \\
\hline
\end{tabular}




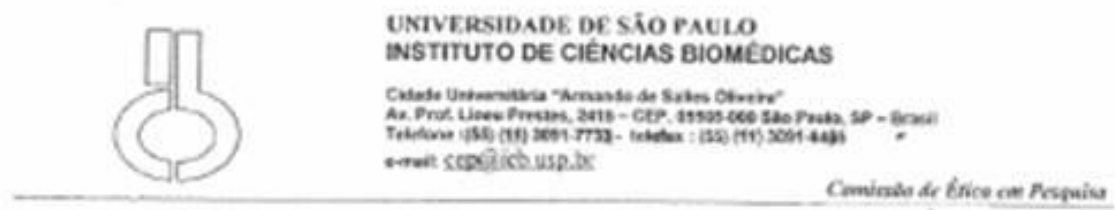

\section{CERTIFICADO DE ISENCC̃̃O}

Certificamos que o Protocolo CBP-ICB N" 413/10 referente ao projeto intitulado: "Estudo dos efeitos da MT.I, uma fosfolipase A2 isolado do veneno de Botbrops asper, sobre a desgranulaçào e ativaçao dos mastócitos.Envolvimento de protéfnas sinalizadoras $\ell$ do cálcio nesses efeitos" sob a responsabilidade de Marlos Cortez Sampaio, foi analisado na presente data pela CEUA - COMrssto DE ÉtucA No eso DE ANIMAtS e pela CEPSH COMTSAO dE ÉtICA EM PESQUtSA COM SERPS HUMANOS, tendo sido deliberado que o referido projeto nà̉o envolve manipulaçio animal ou humana que justifique uma aprovaçào quanto aos princípios éticos exigidos por ambas as Comissòes.

São Paulo, 10 de agosto de 2010.
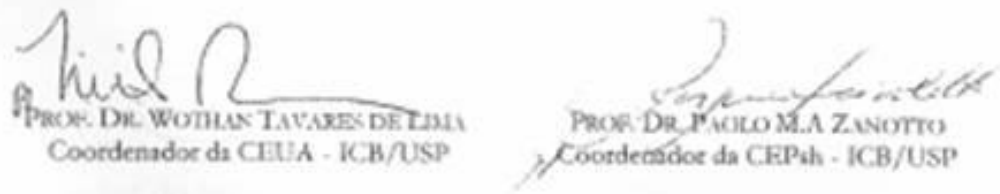


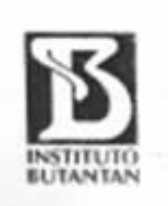

COMISSÃO DE ÉTICA NO USO DE ANIMAIS INSTITUTO BUTANTAN

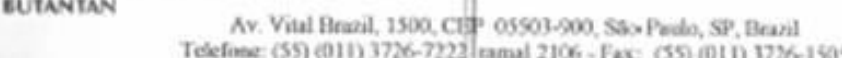

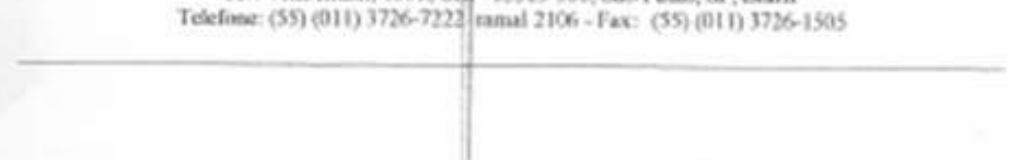

CERTIFICADO DE ISENÇÃO

Certificamos que o projeto intitulado "Estudos dos efeitos da MT-1, uma fosfolipase $\mathrm{A}_{2}$ isolada do veneno de Bothrops asper, sobre a desgranulacáo e ativaçào dos mastócitos. Envolvimento de proteinas sinalizadoras e do cácio nesses efeitos", sob responsabilidade de Catarina de Fátima Pereira Teixeira, foi analisado pela CEUAIB - Comissào de Ética no Uso de Animaís de Experimentaçāo do Instituto Butantan - tendo sido deliberado que o referido projeto nâo envolve manipulaça de animal vertebrado que justifique uma aprovação quanto aos principios éticos exigidos por esta comissào.

São Paulo, 14 de setembro de 2010.

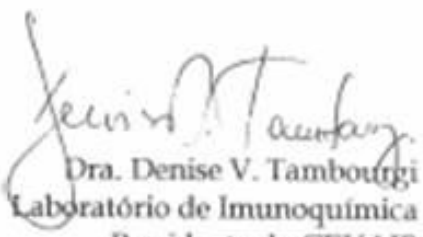
Presidente da CEUAIB

De acordo:

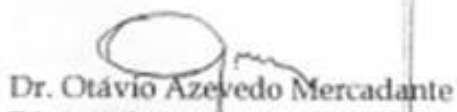

Diretor do Instiquto Butantan 


\section{DEDICATÓRIA}

Dedico este trabalho aos meus pais, Wilson e Fátíma, e à minha irmã, Moníca por sempre me incentivarem a prosseguir com meus estudos e com minhas escolhas, mesmo, muitas vezes, não compreendendo ao certo o que significava. Nestesúltimos 5 anos passamos momentos bem difíceis e complicados mas sempre permanecemos juntos. Sofreram com as minhas frustrações, mas também vibraram com o meu sucesso. Se hoje consegui chegar tão longe, devo tudo a vocês. A felicidade que sinto por ter concluído esta etapa tão intensa e gratificante da minha vida dedico a vocês também. Muito obrigado por serem pessoas maravilhosas que sempre me apoiaram e se esforçaram para que eu pudesse seguir meu caminho. De hoje em diante, espero ser eu quem irá apoiar vocês em seu caminho.

"O amor da familía é o combustivel que capacita um ser humano comum a fazer o impossivel." 


\section{Catarina,}

agradeço pela confiança e pela oportunidade de aprender muitas coisas importantes no laboratório, além da ciência propriamente dita. Tive a oportunidade de aprender muito sobre a rotina de um laboratório, lidar com compras, orçamentos, como elaborar relatórios financeiros e como solucionar os problemas que surgem nesta rotina.

Obrigado por me ajudar a adequar o projeto enorme de doutorado, que tracei inicialmente, de modo que ele fosse executável no tempo que eu tinha. Fora isso, gostaria de agradecer por permitir, muitas vezes, que eu conduzisse meu projeto de doutorado seguindo a linha de raciocínio que eu tinha definido inicialmente. Obrigado por todas as sugestões, discussões e pelo empenho com o meu projeto. Este estudo, no meu ponto de vista, foi muito inovador, explorou vários aspectos diferentes e abre portas para perguntas muito interessantes. Convivemos no laboratório por mais de 10 anos e acabamos tendo alguns desentendimentos, principalmente nos últimos anos, mas acho que isso é comum nos relacionamentos humanos. O mais importante é que soubemos ultrapassar tudo e prosseguir para concluir este estudo que me deixou muito feliz e me fez amadurecer como pessoa e como cientista.

Bom, resumindo, tive bons momentos no laboratório e outros nem tanto, mas o saldo final foi muito positivo, pelo menos para mim. Obrigado pela oportunidade de aprendizado e também pela oportunidade de crescer na adversidade, de enfrentar os desafios envolvidos e de aprender com os meus erros. Todas estas oportunidades me fizeram crescer e amadurecer em vários aspectos. Hoje, me sinto uma pessoa muito mais segura, confiante e determinada.

"Não ande apenas pelo caminho traçado, pois ele conduz somente até onde os outros já foram." 


\section{AGRADECIMENTOS}

Muitas pessoas passaram na minha vida nos últimos 5 anos e será difícil agradecer tudo e à todos. No caso de não citar, não pense que é ingratidão, simplesmente um momento conturbado da minha cabeça com inúmeras informações e prazos da pós que estão ocupando mais espaço no HD mental do que o usual. Assim, agradeço a todos que participaram direta ou indiretamente desta importante etapa da minha vida. MUITO OBRIGADO POR TUDO!

Lívia (Livs), você é uma pessoa incrível! Nossas conversas sempre foram maravilhosas, pois você estava sempre bem humorada, disposta e sempre emanava boas vibrações. Como era impossível não rir perto de você, todo o estresse e a tensão iam embora. Algumas vezes, quando haviam injustiças ou aprontavam com você ou seus amigos queridos, virava um "furacão", mas logo passava e dávamos muitas risadas. Você é uma pessoa muito forte, perseverante e determinada mas, ao mesmo tempo, muito doce, humilde e amável. Tudo isso faz com que você seja admirável e inesquecível!

Ana Du (Ita, pros íntimos, kkkkk), pena que passou pouco tempo no laboratório e que não conseguimos desenvolver muitas coisas juntos pois, a nossa sintonia trabalhando era ótima e produtiva. Adorava o seu jeito meio estressada/preocupada e sempre te assustava perguntando, ao final do experimento, se tinha feito algo importante lá no início (algumas vezes, eu sabia que o tinha feito). Você ficava desesperada, mas durava pouco, até eu rir de você. Isso quando você não se vingava, e fazia o mesmo comigo! Adorava nossas conversas e desabafos, mas, principalmente, adorava fazer experimento contigo. Apesar da seriedade do trabalho que tínhamos, sempre aproveitávamos um espaçinho pra descontração, para um xingamento, uns sustos planejados e calculados. Obrigado por toda a sua prestatividade comigo e pela confiança de sempre me perguntar suas dúvidas sobre protocolos, conceitos imunológicos, cálculos de reagentes mas, principalmente, muito obrigado por ouvi-los e aceitá-los quando estavam certos. Aprendi muito com você e tenho certeza de que seu futuro será muito promissor!

Eduardo Frare, ou simplesmente Du. Difícil agradecer por tantas coisas. Nos conhecemos há muitos anos e desde então, tenho amadurecido, cada vez mais, como ser humano e como profissional. Você é um profissional extremamente competente e agradeço por ensinar com grande maestria e sem vaidade ou orgulho, tudo o que sabe. Você é assistente de pesquisa incrível que vale mais que alguns "punhados de profissionais" juntos! Sempre trabalha muito, com muita honestidade e dedicação e está sempre disposto para ajudar quem precisar. Só uma pessoa extremamente criteriosa como você para me ensinar, com tanta 
paciência, zelo e rigor, a trabalhar no fluxo laminar e com cultura celular. Acho que aprendi bem. Nunca tive problema de contaminação nos 5 anos que trabalhei com cultura. Obrigado por me ajudar com os meus experimentos, enquanto pode. Sempre produzimos muito bem juntos. Pena que não deixaram que continuássemos trabalhando juntos. Tenho certeza de que, juntando esforços, esta tese teria muito mais respostas neste momento. Nossas discussões de protocolos e resultados são sempre muito instigantes e produtivas. Fico contente sabendo o quanto você está feliz neste novo laboratório, trabalhando com o que gosta, com pessoas tão competentes como você e crescendo cada vez mais. Também não poderia deixar de agradecer por sempre se dispor para preparar o "layout" de tudo o que eu lhe pedi, em especial pelas minhas aulas em power point, pelos meus pôsters e pelo esquema final que apresento aqui na tese, tudomuito bem feito e de qualidade impecável! Além de tudo isso, muito obrigado pelo seu companheirismo sincero, pela sua paciência comigo, pelas broncas merecidas que recebi para aprender coisas importantes na minha vida, pelos conselhos sempre muito bem pensados e falados, pelo seu apoio e amizade em momentos felizes, mas, principalmente, nos momentos mais difíceis da minha vida. Por fim, hoje, lhe agradeço eu ser uma pessoa mais "humana" e por ter contribuído para me tornar um profissional muito mais competente, preparado para discutir tudo e propor soluções para os problemas e isso, eu devo à pessoas como você. Muito obrigado por tudo isso e muito mais.

Agradeço aos alunos da Unidade de Inflamação, com quem convivi muitos anos: Marina, Mariana, Márcio, Elbio, Karina, Neide e Vanessa (agora docente da UNIFESP), pela companhia, possibilidade de aprender um pouco com cada um, por me ajudarem e oferecerem ajuda quando precisei, pelas sugestões e por participarem, direta ou indiretamente, desta etapa da minha vida. Agradeço, de modo especial à Mari, por tornar o ambiente de trabalhotão gostoso com a sua simplicidade e alegria e por sempre ajudar a todos, mesmo quando não podia. ÀNeide que, além de tudo, contribuiu de modo importante no meu estudo, com o protocolo para dosagem da atividade enzimática da MT-I e sempre estava disposta a ajudar e conversar e, ao Márcio, com quem me aproximei mais nos últimos anos e sempre me presenteava com sábios conselhos, valiosas discussões de resultados, ajuda importante com a teoria e a prática de alguns protocolos. Agradeço também a Renata Hage, funcionária do laboratório, pelos momentos de descontração, pelas palavras amigas e confortáveis e por sempre nos ajudar a manter tudo o que precisávamos para a nossa pesquisa em ordem.

ÀDra. Cristina Fernandes, pesquisadora da Unidade de Inflamação, colaboradora deste estudo. Cris, a nossa história é muito antiga e sou muito grato a você por tudo o que me fez. Além de me ajudar com discussões científicas, com os ensaios de PCR e com muitas 
outras coisas anteriores, preciso agradecer, de modo especial, por ter me ajudado em um momento muito difícil, quando você ainda era pós-doc e eu estava para entrar no doutorado. Jamais esquecerei o que fez mim, principalmente naquele momento, e saiba que estou retribuindo sempre, conforme combinamos.

Agradeço ao apoio constante de grandes pessoas, Dona Helena (grande amiga que considero como minha segunda mãe), Seu Bruno (que nos deixou, para poder descansar) e Fernando. Vocês sempre me apoiaram e encorajaram para seguir este caminho. Vocês são pessoas maravilhosas e raras, com bom coração e sempre com uma boa história para nos fazer rir ou emocionar. Muito obrigado pela torcida constante.

Paty, minha grande amiga de João Pessoa, muito obrigado por esta amizade tão sincera. Obrigado pelas palavras de apoio em momentos difíceis e por me fazer rir com o seu jeitinho de ser. Vivs, obrigado pelas viagens maravilhosas que fizemos, pelas piadas, pelas conversas. Tudo foi sempre muito bom para relaxar e me preparar para retomar as atividades. Rê Olivo, como foi maravilhoso conviver com você no laboratório. O seu profissionalismo sempre foi algo que eu almejei mas, além disso tudo, não importava os problemas que estivesse passando, sempre estava alegre, feliz e fazia todo mundo rir, mesmo que fosse de mim, né? Sempre me lembro que colocava fantasias em mim, tirava sarro, falava besteiras mas sempre se preocupava comigo e cuidava muito bem de mim. Era maravilhoso dividir o ambiente de trabalho contigo, pena que estreitaram o seu tempo e foi obrigada a sair mais cedo. Sempre me lembro de você com muito carinho, admiração e alegria. Dani, pena que o seu tempo também foi reduzido. Tínhamos uma sintonia maravilhosa e trabalhávamos muito bem juntos. Você sempre trabalhou com muito cuidado e com muita alegria. Muito obrigado pelos bons momentos que passamos juntos e por receber, de bom grado, um pouco do conhecimento que eu tinha para oferecer e obrigado por me mostrar toda a determinação e caráter.

Agradeço aos amigos do Butantan com quem convivi e pude sempre contar com o apoio. Liana, além de sua prontidão em ajudar, sempre tinha conselhos preciosos para dar e uma paz de espírito impressionante e contagiante. Gilda, minha amiga mais "lindinha", muito obrigado por toda a preocupação e o cuidado que tem por mim. A sua alegria sempre jovial e a sua simpatia conquista a todos. Vilminha, nos conhecemos há muito tempo, né? Sempre gostei de bater papo com você. Você é uma pessoa muito doce, meiga e que sei que torce muito por mim. Muito obrigado por tudo inclusive pela torcida e pelos desabafos. Edna, que apesar do pouco tempo que nos conhecemos, sempre foi muito alegre e irreverente e sempre me divertia com o seu jeito. Cleusa, meus dias ficam tão felizes quando consigo te encontrar 
no Butantan! Você tem uma luz dentro de você que se irradia para nós quando abre esse seu grande e lindo sorriso. Você sempre traz consigo muita alegria, jovialidade, pensamentos positivos e animação você consegue fazer com que a gente não queira sair de perto de você! Muito obrigado por ser essa pessoa maravilhosa que traz tanta alegria por onde passa.

Agradeço aos amigos e colegas da Farmacologia, dentre eles os "Proibidões do café" que era um grupo muito animado de alunos que se reuniam para preparar café da manhã que eram deliciosos, até nos proibirem. Agradecer, de modo especial, aos amigos com quem convivo quase diariamente, Rodrigo (Fioto), Mari e Paty, muito obrigado pelos ótimos momentos juntos e pelas piadas. Rafitcha, muito obrigado pelas conversas, desabafos e sugestões maduras, por todo o apoio e, principalmente, por você ser essa pessoa tão iluminada, amigável, bondosa e gracinha. Obrigado a Dri Loira e Morena por serem pessoas tão legais, pelas risadas e bom convívio.

Agradeço ao Henrique Rofatto, responsável técnico pelo confocal do Butantan, pelo suporte quando fiz alguns ensaios de confocalidade com as minhas células. Ao André, funcionário do Lab. de Fisiopatologia, por me ajudar com os ensaios de atividade enzimática das fosfolipases. Agradeço ao Doutor Carlos Jared e à Simone, responsável técnica pelo microscópio eletrônico de transmissão do laboratório de Biologia Celular. Simone, muito obrigado por me acompanhar com a captura das primeiras imagens e por me ensinar como manusear o microscópio para que eu pudesse capturar as imagens. Foi sempre foi muito solicita e simpática.

À todos os funcionários do Laboratório de Farmacologia, tanto pesquisadores quanto os funcionários de apoio. Agradeço, de modo especial àqueles com quem tive mais contato e que pude trocar experiências inesquecíveis, como a Joana e a Sônia, secretárias do laboratório. Vocês foram maravilhosas, cada uma do seu jeito, como água e vinho (rs), mas se completavam e trabalhavam juntas com extrema precisão. Vocês foram indispensáveis para o funcionamento do laboratório. Obrigado por sempre estarem à disposição quando precisei, pelas conversas sempre muito gostosas e pelas risadas. Sônia, só uma informação, pouquíssimas pessoas sabiam como driblar aquela sua marra de sargentona, que é só fachada, mas fique tranquila, eu não vou contar pra ninguém! Kkkkkk. Seu Antônio, a sua determinação, força de vontade, disposição e otimismo são invejáveis! Um senhor que trabalha feito "gente grande", né? É impressionante e admirável como dá conta de trabalhos tão pesados, por tanto tempo e sem reclamar! E ainda consegue ser uma pessoa maravilhosa, transparente, alegre, feliz e com um coração puro e nobre. Leo (que agora faz parte do outro laboratório), obrigado por todo o apoio e pelas conversas sempre amigáveis. Você é uma 
pessoa muito boa e merece ser muito feliz e, hoje, podemos ver essa alegria no seu rosto, o que nos deixa muito feliz! Elisa, você é incrível! Uma profissional espetacular, dedicada e extremamente competente! Além de cuidar de tudo o que era possível para nos ajudar, ainda podia contar com seus sábios conselhos e por um carinho muito especial apesar da pose de durona, né? Kkkkk. Dona Binha e Zelma, jamais me esquecerei de vocês. Guardarei sempre com muito carinho os bons momentos, o cuidado que tinham com a gente e toda a dedicação e esforço para nos ajudar. Adorava bater nossos papos e rir com vocês. À todos os amigos que fiz no laboratório, o meu muito obrigado pelo convívio tão gostoso e alegre.

Agradeço aos Doutores José María Gutiérrez e Bruno Lomonte, do Instituto Clodomiro Picado, na Costa Rica, por fornecerem as miotoxinas utilizadas neste estudo e por sempre se mostrarem muito entusiasmados com este trabalho, por sempre responderem prontamente as minhas questões e pelas conversas e discussões que tivemos, sempre muito produtivas.

Agradeço à Dra. Aurora Cianciarullo, Lab. de Genética, do Instituto Butantan. Muito obrigado por abrir seu laboratório e pela disponibilidade de me ensinar com tanto carinho, competência e propriedade como fazer e analisar a microscopia eletrônica e, principalmente, por dividir seu rico e apaixonante conhecimento de biologia celular. Todo este conhecimento me ajudou a compreender os resultados que obtive. Além disso, muito obrigado pelas ótimas e agradáveis conversas que sempre temos. Agradeço também por pedir para as suas alunas Erica e Raquel Canali (agora funcionária do Butantan) por me acompanharem com os procedimentos da técnica. Meninas, muito obrigado por disponibilizarem seu tempo para me ajudar, pelos ensinamentos e por toda a simpatia que tiveram por mim.

Agradeço imensamente às Dras. Constance Oliver e Maria Célia Jamur, da Faculdade de Medicina, da USP Ribeirão, pessoas maravilhosas que abriram seu laboratório para eu que pudesse aprender os procedimentos de cultivo da RBL, por me doarem células RBL, que haviam sido recentemente retiradas de ratos, pela possibilidade de aprender um pouco os procedimentos para fazer microscopia de fluorescência com estas células, por estarem sempre tão disponíveis e solícitas para me atender e esclarecer minhas dúvidas, por auxiliarem de modo tão preciso e rápido, a interpretar alguns fenômenos que observei quando obtive as imagens de microscopia eletrônica. Pena que não pude desenvolver um trabalho mais duradouro com sua colaboração, mas, mesmo assim, aprendi muitas coisas valiosas em muito pouco tempo de contato. Além de tudo, preciso agradecer a gentileza e simpatia que oferecem sempre que conversamos. Já faz alguns anos que estive em seu laboratório e não me lembro do nome de todos os seus alunos daquela época mas preciso agradecer à algumas 
alunas que me ajudaram muito com discussões e protocolos dentre elas a Adriana, a Vivian, a Elaine e a Maria Rita. Muito obrigado pela atenção e orientações que me deram.

Aproveito para agradecer também à Dra. Eliana Faquim, do Lab. de Imunopatologia, do Instituto Butantan, por doar os "vials" de RBL que utilizei no início do doutorado e por colaborar intensamente com este estudo, principalmente no início, quando tive várias dúvidas relacionadas às células e estava com dificuldade de padronizar os ensaios iniciais. Obrigado por sempre abrir espaço na sua agenda para me atender, por discutir diversos assuntos relacionados com a minha tese e contribuir para a minha formação. Você tem colaborado comigo mesmo antes do doutorado e por isso, sou muito grato por tudo o que fez e ainda faz e espero sempre poder retribuir com a mesma gratidão. Ainda, além da indiscutível competência profissional e científica, você sempre foi muito simpática e gentil comigo. Tenho muita admiração por você, como pessoa e como profissional, e tenho orgulho de ter feito parte da minha formação.

Agradeço aos Professores da minha banca de qualificação por disponibilizarem seu tempo para ler o meu trabalho, pelas correções e sugestões e por discutirem os meus resultados de maneira tão produtiva. Professor Wilmar Dias da Silva (Lab. de Imunoquímica), muito obrigado pelas sugestões. Muitas delas foram realizadas e realmente foram importantes para o trabalho. Ainda, agradeço às Dras. Sandra Coccuzzo Sampaio (Lab. de Fisiopatologia) e Eliana Faquim, pela conversa que tivemos alguns dias após a qualificação quando desfizeram uma impressão errada que me passaram.

RosanaPrisco, mais uma etapa concluída! Muito obrigado pela competência e seriedade para analisar estatisticamente meus resultados. Obrigado por me ensinar conceitos de estatística com tamanha didática e dedicação. Além disso, muito obrigado pelas nossas conversas maravilhosas e restauradoras (na verdade, pelas terapias que vinham no pacote quando marcávamos consulta para analisar a estatística dos meus resultados). Você é uma profissional incrível, que recomendo a todos do ICB, é uma pessoa doce, meiga, de bom coração e maravilhosa.

Muito obrigado a todos os funcionários da biblioteca do ICB-USP:Maria do Socorro, Antônio Paulo (XUXA), Yoshiyuki, Nilton, Delza, Jacinta e Monica, muito obrigado por tanta prestatividade, pela simpatia e pela gentileza de ajudar sempre e da melhor maneira possível. Agradeço, de modo especial, à Tereza, por todo o carinho, disponibilidade e dedicação ao revisar a padronização da minha tese. À Valéria pela simpátia e alegria contagiante e por me ajudar a não arrancar os cabelos para formatar a numeração daas páginas.Ao Edilson, por todas as várias vezes que enchi sua paciência solicitando artigos e 
livros que não estavam disponíveis e pelas conversas sempre amigáveis e divertidas. A Renata que tem me ajudado muito, desde o mestrado. Muito obrigado pelos buscar os artigos que eu precisava, mas não tinha acesso e principalmente, pela sua disposição constante em ajudar, pelas conversas sempre agradáveis e por todo o apoio que me deu na padronização da tese. À Rosa pelo cuidado com a elaboração da ficha catalográfica e de aprovação.

Ao Gaspar Ferreira de Lima, do Departamento de Biologia Celular e Desenvolvimento, do ICB - USP, por ter realizado os cortes ultrafinos e contribuido com a obtenção das amostras para microscopia eletrônica.

Aos funcionários do Departamento de Imunologia: Eni (secretária da Pós), muito obrigado por tudo o que fez por mim, por tanto profissionalismo, pelos puxões de orelha corretivos nos momentos certos, pelas conversas sempre muito gostosas, por toda a atenção e cuidado que teve e tem por mim e por todos os alunos do programa. Você é uma mãezona para todos nós. João (secretário da Graduação) e Amanda (Gerente de Projetos), muito obrigado por me ajudarem sempre que precisei. À Jotelma (secretária do Departamento), ainda guardo com carinho toda a dedicação, carinho e competência que tinha pelos alunos e por mim quando era secretária da Pós.

Tive contato com poucos funcionários de apoio do Departamento de Imuno mas foram sempre muito produtivos e agradáveis! Agradeço à Meire Hiyanee Andrea Glatt, especialistas de laboratório, por terem me ajudado com a dosagem do kit multiplex e com a citometria quando precisei. Agradeço também por terem sido sempre tão solicitas e prestativas e pelas conversas sempre muito agradáveis. À Silvana Aparecida da Silva, do Laboratório da Professora Sônia Jancar, pelo carinho a atenção, sempre que precisei.

À todos os professores do Departamento de Imunologia, por terem contribuído com a minha formação e agradeço de modo especial à Dra. Lourdes pela disposição constante em ajudar e ensinar, à Maristela pelas conversar sempre muito interessantes, por contribuir com discussões científicas dos meus resultados e por me propiciar tantas oportunidades de crescimento científico em diversas áreas. À Dra. Sônia Jancar por tanta simpatia, pelos ensinamentos e, juntamente com o Professor Anderson de Sá Nunes, por terem me orientado no PAE. Esta etapa foi muito importante para o meu crescimento.

Aos coordenadores da Pós em Imuno. A Dra. Maria Regina D'Império Lima era a coordenadora quando entrei e me lembro da sua preocupação para que eu tivesse uma bolsa. Logo depois, assumiu o Professor Gustavo Amarante, a quem agradeço pelas excelentes oportunidades de crescimento profissional e científico, por tudo o que fez pelo programa de pós e pelos alunos, por propiciar a participação dos alunos em congressos e, principalmente, 
pelo apoio e pelos sábios conselhos que recebi em um momento muito crítico do meu doutorado. Agradeço também ao atual coordenador, Professor Niels, por tudo o que fez e faz pelo programa e pelos alunos. É sempre muito bom te encontrar e trocar algumas palavras contigo e mais que isso, obrigado por abrir as portas do seu laboratório para que eu pudesse dosar o kit multiplex com a Meire.

Agradeço ao Programa de Pós-graduação pela bolsa CAPES que recebi durante o doutorado, sem a qual, seria impossível desenvolver este estudo.

Finalmente, mas não menos importante, agradeço a Deus por me guiar ao longo destes anos. Agradeço por colocar tantas pessoas importantes na minha vida. Este doutorado, mais do que um crescimento científico e profissional, foi um aprendizado de vida. Muitas pessoas "boas" e outras "nem tanto" passaram no meu caminho, mas mesmo essas outras pessoas foram importantes, pois, sem o convívio com elas, não teria aprendido a dar valor as coisas mais simples e significativas da vida como a amizade verdadeira e desinteressada, perdoar as pessoas e o amar a nós mesmos e ao próximo. Ainda, aprendi com essas pessoas a não julgar seus defeitos e procurar os meus próprios defeitos para corrigi-los. Para as "boas" pessoas, o sentimento de gratidão é ainda maior. Vocês foram, em muitos momentos, meu ponto de apoio e minha válvula de escape para seguir com perseverança e determinação. Agradeço sempre a Deus por ter me dado força nos momentos de fraqueza, sabedoria nos momentos conturbados e paciência nos momentos de estresse. Também agradeço por ter colocado na minha vida pessoas maravilhosas que contribuíram para o meu crescimento pessoal e profissional com amor ou com desafios.

"Todas as grandezas desse mundo não valem um bom amigo." Voltaire

"Tudo vale a pena quando a alma não é pequena." Fernando Pessoa 
"Um pouco de ciência nos afasta de Deus. Muito, nos aproxima" - Louis Pasteur

"As difículdades domadas, são oportunidades conquistadas"

- Winston Churchill 


\section{RESUMO}

SAMPAIO, M. C.Efeitos da MT-I, uma fosfolipase $\mathbf{A}_{2}$ isolada do veneno de Bothrops asper em mastócitos: Ativação e sinalização intracelular envolvida na desgranulação. 2015. 113 f. Tese (Doutorado em Imunologia) - Instituto de Ciências Biomédicas, Universidade de São Paulo, São Paulo, 2015.

As fosfolipases $\mathrm{A}_{2}$ secretadas $\left(\mathrm{sFLA}_{2} \mathrm{~s}\right)$ são enzimas abundantes em venenos de serpentes e ativam várias células imunológicas, dentre as quais os mastócitos. Quando estimuladas, estas células liberam mediadores que contribuem para o início e o desenvolvimento da resposta inflamatória. A capacidade de algumas fosfolipases $\mathrm{A}_{2}$ ofídicas estimularem a desgranulação de mastócitos foi demonstrada anteriormente, porém os mecanismos deste efeito não foram esclarecidos. Além disso, os efeitos dessa classe de enzimas sobre outras funções imunológicas dos mastócitos ainda não foram investigados. Deste modo, este estudo teve por objetivo avaliar as ações da Miotoxina-I (MT-I), uma fosfolipase $\mathrm{A}_{2}$, isolada do veneno de Bothrops asper (VBa), na ativação e desgranulação de mastócitos de rato, da linhagem RBL$2 \mathrm{H} 3$, do ponto de vista da: i) relação concentração-efeito e perfil temporal desgranulação e a liberação de prostaglandina $\mathrm{E}_{2}\left(\mathrm{PGE}_{2}\right)$; ii) participação da atividade enzimática na desgranulação; iii) expressão gênica de citocinas de resposta Th1 (TNF- $\alpha$, IL-1 e IL-6) e Th2 (IL-4, IL-5 e IL-13), iii) participação das fosfolipases D, C e $\mathrm{A}_{2}$ (citosólica e independente de cálcio), de proteínas sinalizadoras (PI3K, MAPK, PKC, PTK, ERK1/2, Junk, proteínas $\mathrm{G}_{\alpha \mathrm{i}} \mathrm{e}$ $\mathrm{G}_{\alpha \mathrm{q}}$ ) e do cálcio intra e extracelular na desgranulação e iv) alterações morfológicas ultraestruturais. Os resultados demonstraram que concentrações não citotóxicas da MT-I induziram a desgranulação dos mastócitos, de modo independente da concentração, mas de intensidade crescente ao longo do tempo (30 min., 3 e 6 h). A atividade enzimática da MT-I é importante, mas não essencial para a desgranulação dos mastócitos e este evento também foi induzido pelo veneno bruto da $B$. asper e pela MT-II (homóloga a MT-I, mas sem atividade enzimática). A MT-I induziu o aumento da endocitose dependente de clatrina, de vesículas citoplasmáticas e induziu a transcrição gênica de TNF- $\alpha$, IL-6, IL-4, IL-5 e IL-13 mas não da IL-1 $\beta$. A desgranulação dos mastócitos, induzida pela MT-I foi dependente das fosfolipases $\mathrm{C}, \mathrm{D}$ e $\mathrm{A}_{2}$ citosólica, da PI3K, do receptor de $\mathrm{IP}_{3}$ (cálcio intracelular) e do CRAC e LTCC (canais de cálcio de membrana celular). Este efeito não foi dependente das proteínas p $38^{\mathrm{MAPK}}$, ERK1/2, PKC, PTK, Junk e das proteínas G. Em conclusão, a MT-I e o VBa causaram a desgranulação dos mastócitos em cultura. Este efeito da MT-I foi dependente do tempo e parcialmente dependente da sua atividade enzimática. Além disso, a MT-I induziu a liberação de $\mathrm{PGE}_{2}$, o aumento do número de vesículas citoplásmáticas e de endocitose e induziu a expressão de genes de citocinas de resposta Th1/Th2. A desgranulação dos mastócitos induzida pela MT-I foi dependente da ativação das fosfolipases C, D e $\mathrm{A}_{2}$ citosólica, da PI3K e do cálcio intra e extracelular, mas não da fosfolipase $\mathrm{A}_{2}$ independente de cálcio, nem das proteínas p38 $8^{\mathrm{MAPK}}$, ERK1/2, PKC, PI3K, PTK, Junk ou das proteínas G. Estes resultados sugerem que as fosfolipases $\mathrm{A}_{2}$ de venenos ofídicos ativam diversas funções de mastócitos e que a desgranulação de mediadores estocadosé dependente de vias de sinalização específicas. Além disso, estes eventospodem contribuir posita ou negativamente na fisiopatalogia local do envenenamento.

Palavras-chave: Miotoxina-I. Fosfolipase $\mathrm{A}_{2}$ secretada, Veneno de Bothrops asper. Mastócitos. Ativação. Desgranulação. Sinalização. 


\begin{abstract}
SAMPAIO, M. C.Effects of MT-I, a phospholipase $\mathbf{A}_{2}$ isolated from Bothrops asper venom, on mast cells: Activation and intracellular signaling involved in degranulation. 2015. 113 p. Ph. D. Thesis (Immunology) - Instituto de Ciências Biomédicas, Universidade de São Paulo, São Paulo, 2015.

Snake venoms secreted phospholipase $\mathrm{A}_{2}\left(\mathrm{sPLA}_{2}\right)$ degranulate mast cells $(\mathrm{MCs})$ but this mechanism and other sPLA $_{2}$ effects on MCs functions is unknow. This study evaluated effects of Myotoxin-I (MT-I), a sPLA ${ }_{2}$ from Bothrops asper venom (BaV), on mast cell RBL$2 \mathrm{H} 3$, focusing on: i) degranulation and prostaglandin $\mathrm{E}_{2}\left(\mathrm{PGE}_{2}\right)$ release; ii) role of enzymatic activity on degranulation; iii) Th1/Th2 cytokines gene expression, iii) role of phospholipase $\mathrm{D}, \mathrm{C}$ and $\mathrm{A}_{2}$ (cytosolic and calcium-independent), PI3K, MAPK, PKC, PTK, ERK1 / 2, Junk, Gai and Gaq protein and calcium on degranulation and iv) ultrastructural morphological alterations. Results showed that MT-I, at non-cytotoxic concentrations, causes RBL-2H3 mast cell degranulation. This effect was partially dependent of its enzymatic activity and dependent on cytosolic phospholipase $\mathrm{A}_{2}, \mathrm{C}$ and $\mathrm{D}$, but not calcium-independent phospholipase $\mathrm{A}_{2}$. Furthermore, PI3K is also involved in MT-I effect but not ERK1/2, p38MAPK, PKC, MEK, Junk, Gai and Gaq proteins. Furthermore, intracellular calcium, from endoplasmic reticulum, and extracellular, via activation of CRAC and LTCC receptors contribute for MT-I effect on mast cells. Besides degranulation, MT-I activated other important functions on mast cells, such as synthesis and release of $\mathrm{PGE}_{2}$, Th1 and Th2 cytokines genes activation, increase of cytoplasmic vesicles number and clathrin-dependent endocytosis. Further, B. asper snake venom caused mast cell degranulation by a direct action and this suggest MT-I is an important component for venom effect.
\end{abstract}

Keywords: Myotoxin-I. Secreted phospholipase $\mathrm{A}_{2}$. Bothrops asper venom. Mast cells. Activation. Degranulation. Signaling. 


\section{LISTA DE FIGURAS}

1 - Sítios de ação de fosfolipases.

2 - Ilustração com principais moléculas e eventos envolvidos na ativação de mastócitos após ligação cruzada do antígeno com a IgE.

3 - Cromatograma das Miotoxinas isoladas do veneno de $B$. asper................................................. 42

4 - Efeito citotóxico de concentrações crescentes da MT-I em mastócitos em cultura................ 52

5 - Desgranulação de mastócitos induzida por concentrações crescentes de MT-I....................... 53

6 - Cinética da desgranulação de mastócitos induzida pela MT-I em mastócitos em cultura.

7 - Efeito da MT-I enzimaticamente inativada e da MT-II na desgranulação de mastócitos em cultura.

8 - Efeito dos inibidores de proteínas quinase na desgranulação de mastócitos induzida pela MT-I.

9 - Ativação da PI3K em mastócitos incubados com a MT-I.......................................................... 59

10 - Efeito dos inibidores das fosfolipases $A_{2}$ intracelulares, C e D na desgranulação de mastócitos induzida pela MT-I.

11 - Efeito dos inibidores das proteínas $G_{a \mathrm{i}}$ e $G_{a q}$ na desgranulação de mastócitos induzida pela MT-I.

12 - Efeito dos inibidores de cálcio na desgranulação de mastócitos induzida pela MTI...

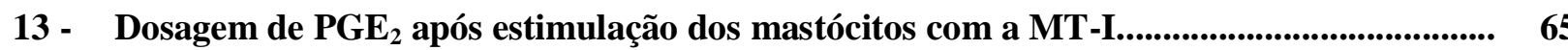

14 - Efeito da MT-I na expressão gênica de mastócitos em cultura............................................... 67

15 - Imagem ultraestrutural de mastócitos controle..................................................................... 69

16 - Imagem ultraestrutural de mastócitos ativados pela MT-I.................................................. $\quad 70$

17 - Imagem ultraestrutural de mastócitos ativados pela MT-I..................................................... 71

18 - Imagem ultraestrutural de mastócitos ativados pela MT-I................................................... 72

19 - Efeito da MT-I no número de vesículas secretórias de mastócitos........................................... 73

20 - Efeito do veneno de Bothrops asper (VBa) na desgranulação de mastócitos em

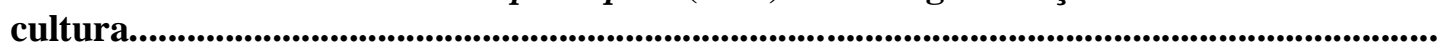

21 - Representação esquemática dos mecanismos de ação da MT-I na desgranulação dos mastócitos RBL-2H3. 


\section{LISTA DE TABELAS}

1 - Inibidores farmacológicos utilizados para avaliar a participação de proteínas sinalizadoras e de receptores na desgranulação dos mastócitos ativados pela MT-I.

2 - Sequência de "primers" utilizados para PCR quantitativo........................................................ 48 


\section{LISTA DE ABREVIATURAS}

ANOVA: Análise de variância

Bel: Bromoenol lactone

bFGF: "basic fibroblast growth factor "

BPB: brometo de para-bromo fenacila

BSA: "Bovine serum albumin"

C3aR: "C3a Receptor"

C5aR: "C5a Receptor"

CD:"Cluster of diferenciation"

CR3: complement receptor 3

CR5: complement receptor 5

D.O.: densidade óptica

DAG: diacilglicerol

DMEM: meio Eagle modificado por Dulbecco

DMSO: Dimetilsulfóxido

EDTA: ácido etilenodiamino tetra-acético (do inglês "Ethylenediamine tetraacetic acid"

EIA:Ensaio imunoenzimático

EPM: Erro padrão da média

ERK1/2: "Extracellular signal-regulated kinases"

Fc $\gamma$ RI: "Fc-gamma receptor 1"

FceRI:"Fc-epsilon receptor I"

$\mathrm{FLA}_{2} \mathrm{~s}$ : fosfolipases $\mathrm{A}_{2}$

FLC: fosfolipase $\mathrm{C}$

FLD: fosfolipase D

h: hora

Herb A: Herbimicina A

HPLC: "High-performance liquid chromatography"

ICa: ionóforo de cálcio A23187

ICAM-1: "Intercellular Adhesion Molecule-1"

IFN: interferon

IL: interleucina

$\mathrm{IP}_{3:}$ inositol trifosfato

$\mathrm{IP}_{3} \mathrm{R}$ : Receptor de inositol trifosfato

JNKi: "Junk Inhibitor II"

kDa: quilo Dalton

LAT: "Linker of Activation of T Cells"

LDH:Lactato desidrogenase

LTCC: Canais de cálcio tipo L (do inglês "L-type calcium channel")

MAPK: "Mitogen-activated protein kinases"

MCP: "Monocyte Chemotactic Protein"

MCs: mastócitos

MIP: "Macrophage Inflammatory Protein" 
$\mu \mathrm{L}:$ microlitro

$\mu \mathrm{M}$ : micromolar

$\mathrm{mL}$ : mililitro

mM: milimolar

MT-I: Miotoxina I

MT-II: Miotoxina II

MTT: brometo de 3-(4,5-dimetil-2-tiazolil)2,5-difenil-2H-tetrazolium

NADH: "nicotinamide adenine dinucleotides hydrate"

NAG: p-nitrofenil-N-acetil- $\beta$-D-glucosamina

Nife: Nifedinamida

nm: nanometros

NTAL: "Non-T-Cell Activation Linker"

PAF: Fator ativador de plaquetas (do inglês "Platelet-activating factor")

PBS:tampão fosfato salina

PD: PD98059

pg: picograma

$\mathrm{PGE}_{2}$ : prostaglandina $\mathrm{E}_{2}$

pH: potencial Hidrogeniônico

PI3K: "Phosphoinositide 3-kinase"

PKC: "Protein kinase C"

PTK: "Protein Tyrosine Kinase"

RANTES: "regulated on activation, normal T cell expressed and secreted"

RBL-2H3: "Rat Basophilic Leukemia"

SB: SB202190

SCF: "Stem Cell Factor"

SFB: Soro fetal bovino

sFLA $_{2} \mathrm{~s}$ : Fosfolipases $\mathrm{A}_{2}$ secretadas

SNAREs "Soluble N-ethylmaleimide sensitive factor attachment protein receptors"

STIM1: "Stromal Interaction Molecule 1"

TEM: "Transmission electron microscopy"

TLR: "Toll-like receptor"

TNF: fator de necrose tumoral

VAMPs: "vesicle-associated membrane proteins"

VBa: Veneno de Bothrops asper

VEGF: "vascular endothelial growth factor"

Xest-C: Xestospongina C

YM: YM-58483 


\section{SUMÁRIO}

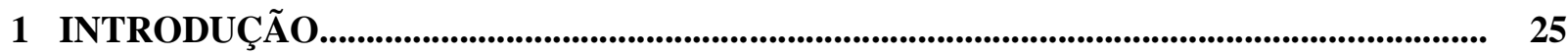

1.1 Fosfolipases $A_{2}$ : considerações gerais............................................................................................. 26

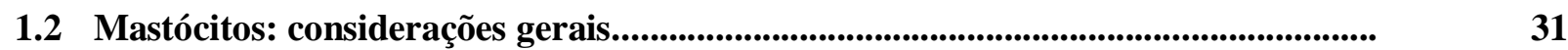

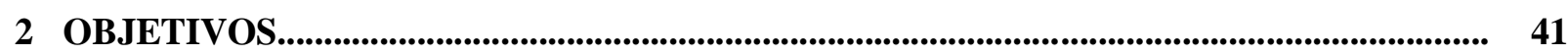

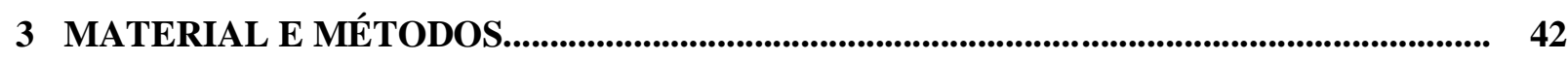

3.1 Veneno de Bothrops asper e as miotoxinas (MT)-I e -II........................................................ 42

3.2 Cultivo de mastócitos murinos da linhagem RBL-2H3.................................................. 42

3.3 Subcultivo e plaqueamento dos mastócitos..................................................................................... 43

3.4 Ensaios de citotoxicidade em células RBL-2H3 ............................................................... 43

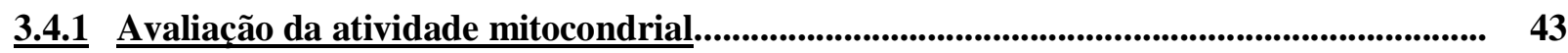

$\underline{3.4 .2}$ Avaliação da integridade da membrana celular................................................................. 44

3.5 Desgranulação de mastócitos............................................................................................................. 44

3.6 Participação de proteínas sinalizadoras na desgranulação de mastócitos induzida pela MT-I..

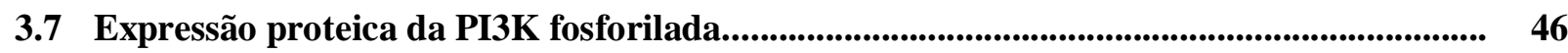

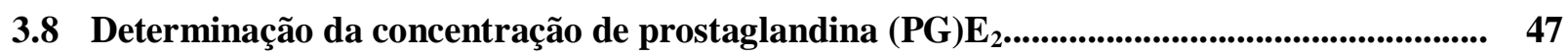

3.9 Expressão gênica de citocinas de perfil Th1/Th2 ....................................................................... 48

3.10 Análise ultraestrutural dos mastócitos incubados com a MT-I........................................... 48

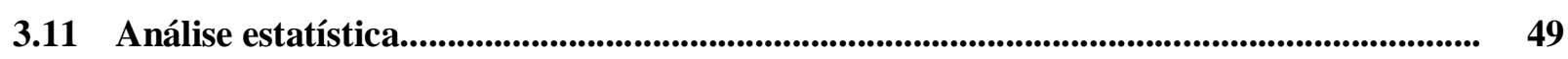

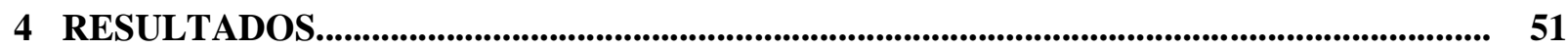

4.1 Efeito da MT-I na viabilidade dos mastócitos em cultura.................................................... 51

4.2 Efeito da MT-I na desgranulação de mastócitos..................................................................... 53

4.3 Perfil temporal do efeito da MT-I na desgranulação dos mastócitos.................................... 54

4.4 Importância da atividade enzimática da MT-I na desgranulação dos

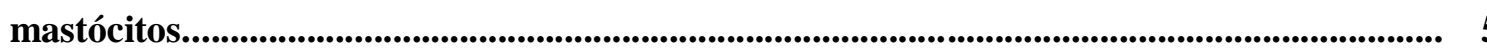

4.5 Participação de proteínas quinases na desgranulação de mastócitos induzida pela MT-

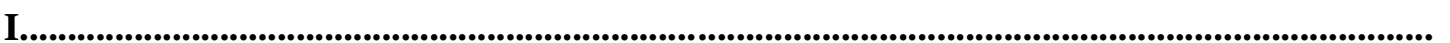

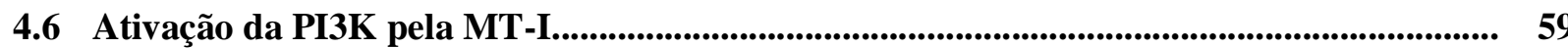

4.7 Participação das fosfolipases $A_{2}$ intracelulares $e$ das fosfolipases $C$ e $D$ na desgranulação de mastócitos induzida pela MT-I........................................................................ 60

4.8 Envolvimento das proteínas $G$ na desgranulação de mastócitos induzida pela MT-

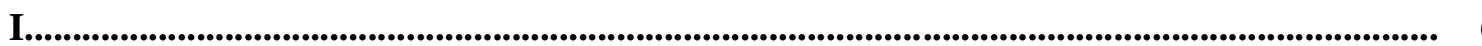

4.9 Envolvimento do cálcio citoplasmático e extracelular na desgranulação de mastócitos induzida pela MT-I.

4.10 Liberação de PGE P̧ $_{2}$ induzida pela MT-I em mastócitos...................................................... 65

4.11 Ativação de genes de citocinas de perfil Th1 e Th2 em mastócitos estimulados pela MT-I.

4.12 Alteraç̃̃es ultraestruturais induzidas pela MT-I em mastócitos.......................................... 68

4.13 Efeito do veneno de Bothrops asper (VBa) na desgranulação dos mastócitos.................... 74

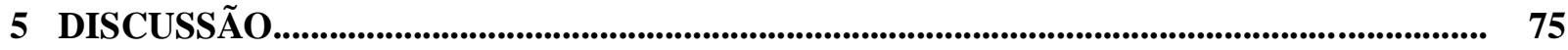

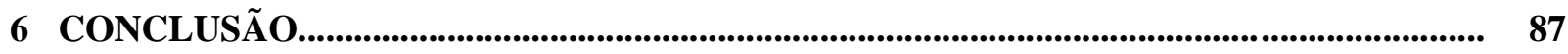




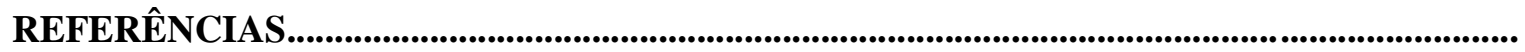




\section{INTRODUÇÃO}

A inflamação é um mecanismo fisiológico da imunidade inata, que tem por finalidade manter ou restaurar a homeostasia frente a um estímulo lesivo ou infeccioso. A resposta inflamatória envolve alterações vasculares, teciduais e linfáticas, que ocorrem ao nível da microcirculação. Esse processo é regulado e modulado por mediadores endógenos e leucócitos residentes, do tecido conjuntivo e/ou recrutados para o sítio inflamatório (MEDZHITOV, 2008). As células residentes são consideradas sentinelas do sistema imune por sua capacidade de reconhecer, prontamente, estímulos lesivos e infecciosos (AJUEBOR et al., 1998, 1999). Dentre estas células estão os mastócitos, elementos centrais no desencadeamento, evolução e resolução da resposta inflamatória, dada a quantidade exuberante de mediadores inflamatórios que são liberados imediatamente após a ativação destas células (GALLI et al., 1999; KALESNIKOFF; GALLI, 2008; QURESHI; JAKSCHIK, 1988). A ativação descontrolada dos mastócitos, contudo, está relacionada ao desenvolvimento de doenças autoimunes graves, como a mastocitose e reações alérgicas severas (GALLI et al., 2005). Ainda, a literatura mostra que os mastócitos são elementos importantes em doenças de origem inflamatória, como a artrite reumatóide, esclerose múltipla, Parkinson, aterosclerose e câncer (CHURCH; LEVI-SCHAFFER, 1997; CRIVELLATO et al., 2004; KALESNIKOFF; GALLI, 2008;OLSSON et al., 2001). Por outro lado, foi demonstrado que os mastócitos foram capazes de reduzir a morbidade e a mortalidade induzida pelo veneno da serpente Atractaspis engaddensis, em camundongos (METZ et al., 2006). Estacapacidade foi atribuída à degradação do componente mais tóxico desse veneno, a sarafotoxina 6b, pela ação da carboxipeptidase A, estocada nestas células e liberada após a sua ativação. Este estudo mostrou, pela primeira vez, o papel dos mastócitos na resistência inata frente a venenos animais (METZ et al., 2006). Nesse sentido, estudos recentes evidenciaram uma importante participação dos mastócitos para a inicialização e o desenvolvimento da resposta inflamatória local induzida pelo veneno da serpente Bothrops moojeni (GALVÃO NASCIMENTO et al., 2010). Além disso, estes autores mostraram que este veneno causou a desgranulação e a ativação de mastócitos de tecido conjuntivo, a partir de uma ação direta do mesmo.

Os venenos botrópicos compreendem uma mistura complexa de proteínas e peptídeos, com diferentes atividades biológicas. Na composição dos venenos botrópicos, destacam-se três grandes classes de enzimas, as metaloproteases, as fosfolipases $\mathrm{A}_{2}\left(\mathrm{FLA}_{2} \mathrm{~S}\right)$ e as serinoproteases (CALVETE et al., 2007, 2009; FOX; SERRANO, 2008; PAES LEME et al., 
2008), que são as principais toxinas responsáveis pelos efeitos locais dos venenos botrópicos (GUTIERREZ et al., 2007; ROTHSCHILD; ROTHSCHILD, 1979; TEIXEIRA et al., 1994, 2009). Neste contexto, diversos estudos demonstraram que as $\mathrm{FLA}_{2}$ scontribuem de modo relevante para o desenvolvimento da resposta inflamatória local, induzida pelos venenos botrópicos (LANDUCCI et al., 1998; MOREIRA et al., 2009; TEIXEIRA et al., 2003; ZULIANI et al., 2005). A ação inflamatória das fosfolipases $\mathrm{A}_{2}$ é atribuída à sua capacidade de liberar ácido araquidônico e acarretar, a partir deste, a formação de eicosanóides, mediadores relevantes da resposta inflamatória.

As evidências da literatura apontaram a capacidade das fosfolipases $\mathrm{A}_{2}$, isoladas dos venenos de serpentes do gênero Bothrops e Crotalus, desgranularem mastócitos "in vitro" e implicaram estas células como um alvo dessas enzimas e como elementos envolvidos em seus efeitos pró-inflamatórios (GUIMARÃES et al., 2004; KANASHIRO et al., 2002;LANDUCCI et al., 1998, 2000). No entanto, os mecanismos, envolvidos na desgranulação dos mastócitos, causada pelas FLA $_{2}$ s, não foram esclarecidos (GALLI; TSAI, 2008; LANDUCCI et al., 1998, 2000). Deste modo, considerando a importância dos mastócitos em processos imunológicos e, particularmente, na resposta inflamatória, os estudos que investiguem os mecanismos da ação de $\mathrm{SFLA}_{2} \mathrm{~S}$, como a Miotoxina-I (MT-I), no que se refere à ativação e à desgranulação destas células, revestem-se de importância.

\subsection{Fosfolipases $\mathrm{A}_{2}$ : considerações gerais}

As fosfolipases compreendem uma ampla classe de enzimas $\left(A_{1}, A_{2}, C\right.$ e $\left.D\right)$ que catalisam a hidrólise de fosfolipídeos em quatro posições diferentes e liberam ácidos graxos (BROWN et al., 2003; GUTIÉRREZ; LOMONTE, 1997), como exemplificado a seguir:

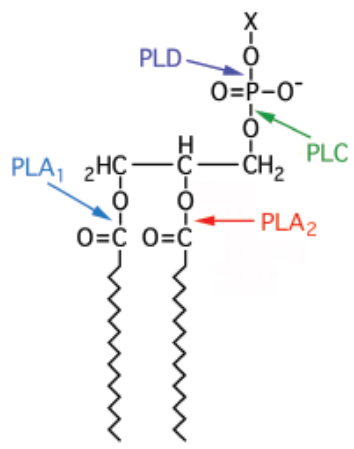

Figura 1- Sítios de ação de fosfolipases (BROWNet al.,2003)

Estas enzimas desempenham importantes funções, em vários processos biológicos, por induzirem a síntese de segundos mensageiros lipídicos, que exercem ações biológicas 
relevantes e participam da transdução de sinais intracelulares (GUTIERREZ; LOMONTE, 2013; MURAKAMI et al., 2011; VALENTIN; LAMBEAU, 2000).

As fosfolipases $\mathrm{A}_{2}\left(\mathrm{FLA}_{2} \mathrm{~s}\right)$ ou fosfatidil-acil-hidrolases, catalisam, especificamente, a hidrólise da ligação acil-éster, na posição $s n-2$ de fosfolipídeos. Esta reação é dependente de íons cálcio e libera quantidades equimolares de ácidos graxos livres e lisofosfolipídeos (DENNIS, 1994; VAN SCHARRENBURG et al., 1982). Os resíduos que participam da alça de ligação para os íons $\mathrm{Ca}^{2+}$, nas $\mathrm{FLA}_{2}$ s, são a Tyr-28, Gly-30, Gly-32 e Asp-49 (FREMONT et al., 1993). A unidade catalítica dessas enzimas é formada pelos aminoácidos His-48, Asp99 e uma molécula de água (LAMBEAU; GELB, 2008; MURAKAMI et al., 2014).

$\mathrm{A}$ ativação das $\mathrm{FLA}_{2} \mathrm{~S}$ leva à formação de ácido araquidônico, precursor de um grupo importante de mediadores lipídicos, que incluem os prostanoides e os leucotrienos. Ainda, as $\mathrm{FLA}_{2} \mathrm{~S}$ geram o liso-PAF, precursor do fator ativador de plaquetas (PAF). Os derivados do ácido araquidônico e o PAF são mediadores de diversos fenômenos fisiológicos e fisiopatológicos (LENNARTZ, 1999; MURAKAMIet al., 1995;VISHWANATH et al., 1987). Desta forma, atribui-se um papel fisiológico relevante às $\mathrm{FLA}_{2}$ sna manutenção da homeostasia celular e na remodelagem de membranas.

Atualmente, mais de 30 fosfolipases $\mathrm{A}_{2}\left(\mathrm{FLA}_{2}\right)$ e enzimas relacionadas foram identificadas no genoma dos mamíferos. As fosfolipases $\mathrm{A}_{2}$ foram agrupadas em famílias e classificadas em $\mathrm{FLA}_{2} \mathrm{~S}$ secretadas $\left(\mathrm{sFLA}_{2}\right)$ e $\mathrm{FLA}_{2} \mathrm{~S}$ intracelulares. Estas últimas compreendem as $\mathrm{FLA}_{2} \mathrm{~s}$ citosólicas $\left(\mathrm{cFLA}_{2}\right)$, as independentes de cálcio(iFLA $\mathrm{i}_{2}$, as acetilhidrolases do fator ativador de plaquetas (PAF-AH) e as fosfolipases lisossomais (SCHALOSKE; DENNIS, 2006). Em outra classificação, as $\mathrm{FLA}_{2} \mathrm{~s}$ foram divididas em 15 grupos, numerados de I a XV, com diversos subgrupos, de acordo com critérios de localização celular, sequência de aminoácidos, peso molecular, presença de pontes dissulfeto intramoleculares e necessidade de cálcio para a atividade enzimática (BROWN et al., 2003; DAVIDSON; DENNIS, 1990; HEINRIKSON et al., 1977; MURAKAMI; TAKETOMI, 2015; RIZZO et al., 2000; SCHALOSKE; DENNIS, 2006; SIX; DENNIS, 2000).

Dentre as $\mathrm{cFLA}_{2} \mathrm{~S}$, são conhecidas cinco isoenzimas: $-\alpha,-\beta,-\gamma,-\delta,-\varepsilon$ e $-\zeta$, sendo que a $\mathrm{cFLA}_{2} \alpha$ é a mais estudada e expressa constitutivamente em muitos tipos celulares e tecidos (HERBERT et al., 2009; MURAKAMI; KUDO, 2002). As $\mathrm{FLA}_{2} \mathrm{~s}$ independentes de $\mathrm{Ca}^{2+}$, pertencem ao grupo VI e contém cerca de 120 aminoácidos ( 84 a 90 kDa). As enzimas deste grupo estão localizadas intracelularmente e não dependem do cálcio para exercerem atividade catalítica (JENKINS et al., 2004; SIX; DENNIS, 2000). As funções fisiológicas exercidas por estas enzimas estão relacionadas, principalmente, ao fornecimento de ácido araquidônico para 
a remodelagem e a manutenção de membranas celulares, porém, dados recentes indicam, ainda, a sua participação na síntese de eicosanóides, na apoptose e na eliminação de células apoptóticas pelos macrófagos (ATSUMI et al., 2000; MURAKAMI et al., 2005; PEREZ et al., 2004; RICKARD et al., 2005; WINSTEAD et al., 2000, 2006).

As fosfolipases do grupo II,também conhecidas como secretadas $\left(\mathrm{sFLA}_{2}\right)$, compreendem o grupo de enzimas mais amplamente estudado, especialmente aquelas pertencentes ao grupo IIA. As sFLA $_{2}$ possuem características relevantes, que estão conservadas neste grupo, tais como o baixo peso molecular (14 a $18 \mathrm{kDa})$, a termoestabilidade, a presença de uma alfa-hélice anfipática amino-terminal, uma alça de ligação ao cálcio, além de um grande número de pontes dissulfídicas intramoleculares (MUKHERJEE et al., 1994; MURAKAMI et al., 2014;RIZZO et al., 2000). As enzimas do subgrupo IIA, como a MT-I, alvo do presente estudo, são encontradas em abundância em venenos de serpentes da família Viperidae. Neste grupo também encontram-se as fosfolipases secretadas humanas, encontradas no fluido sinovial e em outros exsudatos inflamatórios e aquelas sintetizadas por mastócitoshumanos (MURAKAMI; TAKETOMI, 2015; QUACHet al., 2014).

A literatura mostra que as $\mathrm{sFLA}_{2} \mathrm{~S}$ de venenos apresentam uma grande homologia funcional e estrutural com as de mamíferos (DAVIDSON; DENNIS, 1990; KRAMER et al., 1989; SEILHAMER et al., 1989). As sFLA $_{2}$ s de mamíferos, dos grupos V, X e IIA, estão implicadas em diversas doenças de origem inflamatória, como a síndrome do desconforto respiratório no adulto, o choque séptico, a pancreatite aguda, doenças autoimunes como a artrite reumatóide, a doença de Crohn e a colite ulcerativa, além da asma brônquica, a rinite alérgica e a aterosclerose (CHILTON et al., 1996;DIVCHEV; SCHIEFFE, 2008; HAAPAMAKI et al., 1998, 1999; KIM et al., 1995; LIN et al., 1996; MURAKAMI; TAKETOMI, 2015; STADEL et al., 1994; SCHRODER et al., 1980; VADAS, 1984; VADAS; PRUZANSKI, 1986; WEBB et al., 2005).

Os estudos de proteômica dos venenos botrópicos demonstram que as $\mathrm{FLA}_{2}$ compreendem uma das classes de toxinas mais abundantes nos venenos de serpentes deste gênero e sugerem, juntamente com evidências experimentais, que estas toxinas sejam componentes relevantes para as ações dos venenos em sistemas biológicos (ALAPE-GIRÓN et al., 2009; CALVETE, 2007, 2009, 2011; GUTIERREZ et al., 2009; GUTIERREZ; LOMONTE, 2013; LANDUCCI et al., 1998; NADUR-ANDRADE, 2014; VALIENTE et al., 1992). Neste sentido, foi demonstrado que o veneno da serpente Bothrops asper possui de $29 \%$ a $45 \%$ de fosfolipases $\mathrm{A}_{2}$, as quais são atribuídas grande parte dos efeitos locais deste 
veneno. Esta espécie é a responsável pela maioria dos casos de envenenamentos na América Central e em algumas regiões do norte da América do Sul.O envenenamento por esta serpente causa manifestações locais graves, que se iniciam rapidamente após a picada e são caracterizadas por edema, dor, hemorragia, mionecrose, formação de bolhas e dermonecrose (GUTIÉRREZ, 1995; OTERO et al., 2002, 2006).

Dados da literatura demonstram que as $\mathrm{FLA}_{2}$, quando injetadas em animais de experimentação, reproduzem efeitos locais graves do envenenamento, como a mionecrose e a inflamação local, caracterizada por edema intenso. Esta inflamação é decorrente, ao menos em parte, da ação estimulatória das $\mathrm{FLA}_{2}$ sobre células residentes nos tecidos, como os macrófagos, as células endoteliais e os mastócitos, que liberam uma série de mediadores que acarretam o processo inflamatório(CHAVES et al., 1995;FARSKY et al., 1997; GALVÃO NASCIMENTO et al., 2010; GUTIERREZ et al., 2009; GUTIERREZ; LOMONTE, 2013;LANDUCCI et al., 1998; MOREIRA et al., 2009; NADUR-ANDRADE, 2014;TREBIEN; CALIXTO, 1989;VALIENTE et al., 1992). Estes fatos reforçam a relevância das fosfolipases $\mathrm{A}_{2}$ para o efeito inflamatório desses venenos. As $\mathrm{sFLA}_{2} \mathrm{~S}$ de serpentes contribuem também para a regulação das respostas imunológicas e inflamatórias, dada a sua capacidade de aumentar a atividade fagocítica e microbicida de macrófagos, induzir a maturação de células dendríticas e de mastócitos e causar a desgranulação e o recrutamento de mastócitos (LANDUCCI et al., 1998; RAMONER et al., 2005; TAKETOMI et al., 2013; WEI et al., 2009, 2010, 2013; ZULIANI et al., 2005).

De modo geral, estão descritas e bem caracterizadas duas isoformas de sFLA $\mathrm{A}_{2}$ nos venenos de serpentes: aquelas que possuem um aspartato na posição 49 (Asp49) e apresentam atividade enzimática e aquelas que possuem uma lisina na posição 49 (Lys49), destituídas de atividade enzimática (LOMONTE; GUTIÉRREZ, 2011). Ainda, existem outras isoformas de sFLA 2 , com diferentes aminoácidos na posição 49, como serina, arginina, asparagina e glutamina. Contudo, suas funções biológicas são pouco conhecidas (LOMONTE; RANGEL, 2012).

Apesar da diferença entre as sFLA 2 s-Asp49 e sFLA 2 s-Lys49, quanto à atividade enzimática, ambas são capazes de induzir miotoxicidade e resposta inflamatória. De modo similar, ambas induzem perturbação das membranas musculares, por mecanismos ainda não completamente elucidados, levando à lise celular. Quando a atividade enzimática das $\mathrm{SFLA}_{2} \mathrm{~S}-$ Asp49 é inibida, a miotoxicidade é reduzida, sugerindo que a atividade enzimática seja importante, mas não fundamental para esta ação (LOMONTE; GUTIÉRREZ, 2011). 
A partir do veneno da serpente $B$. asper foram isoladas quatro miotoxinas com estruturas de fosfolipases $\mathrm{A}_{2}$, denominadas de MT-I a IV. Apesar de todas apresentarem ação miotóxica, duas delas possuem um aspartato na posição 49 (Asp49) e apresentam atividade enzimática (MT-I e MT-III) e as outras duas (MT-II e MT-IV) são homólogas, contém uma lisina na posição 49 (Lys49) e são destituídas de atividade catalítica (DÍAZ et al., 1995; FRANCIS et al., 1991; GUTIÉRREZ et al.,1984; KAISER et al., 1990; LIZANO et al., 2001; LOMONTE; GUTIÉRREZ,1989).

A literatura descreve diversas ações biológicas para a MT-II e MT-III, no entanto, pouco se sabe sobre a MT-I. Esta FLA 2 possui peso molecular de 14,1 kDa (Dr. José Maria Gutiérrez, comunicação pessoal) e induz a hidrólise de fosfolipídeos de células musculares, causando a sua lise, além de apresentar atividade anticoagulante, hemolítica e proinflamatória (BUTRÓN et al., 1993; DÍAZ-OREIRO; GUTIÉRREZ, 1997;GUTIERREZ et al., 1984; ROCHA et al., 2002). A inativação da atividade fosfolipásica da MT-I não impede a sua ação miotóxica, sugerindo que regiões distintas do sítio catalítico desta enzima devem estar envolvidos em sua a açãomiotóxica (FERNÁNDEZet al., 2013). No entanto, não existem estudos sobre esta $\mathrm{sFLA}_{2}$ quanto à sua ação sobre células inflamatórias, especialmente os mastócitos.

Evidências experimentais utilizando a MT-II, uma FLA2-Lys49, homóloga à MT-I e também isolada do veneno da serpente $B$. asper, mostraram que uma sequência de aminoácidos, localizada na região C-terminal da molécula, é a responsável por desencadear seus efeitos biológicos (CALDERÓN; LOMONTE, 1998;CINTRA-FRANCISCHINELLI et al., 2010; LOMONTE et al., 1994, 1999, 2010; NÚÑEZ et al., 2001; RANGEL et al., 2011).

$\mathrm{Na}$ tentativa de propor um modelo que explicasse a ação das $\mathrm{sLAA}_{2}$ de venenos, foi sugerido que estas enzimas poderiam apresentar um efeito tóxico sobre as membranas celulares e/ou um "efeito farmacológico", decorrente de sua capacidade de se ligar, com alta afinidade, a proteínas específicas (receptores ou aceptores) desencadeando um efeito biológico (GUTIÉRREZ; LOMONTE, 2013; KINI; EVANS, 1989).

Com o avanço dos estudos das $\mathrm{SLAA}_{2} \mathrm{~s}$, parte dos efeitos das $\mathrm{FLA}_{2} \mathrm{~s}$ de venenos e de mamíferos, sobre diferentes células, foi relacionada à sua capacidade de originar segundos mensageiros, derivados do ácido araquidônico e de lisofosfolipídeos de membrana. Posteriormente, foi demonstrada a capacidade de algumas $\mathrm{sFLA}_{2} \mathrm{~s}$ (de venenos) interagirem com receptores do tipo $\mathrm{M}$ (muscular) e do tipo $\mathrm{N}$ (neuronal), presentes nas membranas celulares. Os receptores do tipo $\mathrm{N}$ foram os primeiros a serem descritos e são expressos no tecido cerebral de ratos. Estes receptores ligam-se com alta afinidade a $\mathrm{sFLA}_{2} \mathrm{~s}$ neurotóxicas, 
do grupo IB. Já os receptores do tipo M foram identificados no músculo esquelético de coelhos e, posteriormente, em neutrófilos, monócitos e macrófagos alveolares (LAMBEAU et al., 1990; LAMBEAU; GELB, 2008; MURAKAMI et al., 2010; RIZZO et al., 2000; SILLIMAN et al., 2002). Estudos mais recentes demonstraram que os receptores do tipo $\mathrm{M}$ pertencem à família dos receptores de manose (da superfamília da lectinas tipo C) e sua ativação, pelas $\mathrm{SFLA}_{2} \mathrm{~s}$, desencadeia uma sinalização intracelular que leva a ativação da via da PI3K (PARK et al., 2003). Este receptor transmembrânico, após sua ligação à sFLA2, é internalizado e pode ser degradado por enzimas lisossomais, sugerindo um papel deste receptor na degradação das sFLA 2 (HANASAKI; ARITA, 1992; SRIBAR; KRIZAJ, 2011; ZVARITCH et al., 1996). Ainda, outros alvos da ligação das sFLA 2 Lys49 e Asp49 foram identificados como o receptor 2 do fator de crescimento vascular endotelial (VEGFR2), ao qual ligam-se com alta afinidade. Curiosamente, a região de ligação das $\mathrm{sFLA}_{2} \mathrm{~s}$ à este receptor é a mesma da porção C-terminal, considerada como o "sítio tóxico", já descrito anteriormente. Além disso, algumas $\mathrm{sFLA}_{2} \mathrm{~s}$ humanas e de serpentes foram capazes de se ligar a integrinas de membrana e induzir diferentes respostas biológicas, como a inibição da migração de células tumorais (BAZAA et al., 2009; FUJISAWA et al., 2008; SAEGUSA; AKAKURA, 2008; YAMAZAKI et al., 2005). Estas informações corroboram a teoria de que as $\mathrm{sFLA}_{2} \mathrm{~s}$, de um modo geral, apresentam não somente um efeito tóxico e que podem ter várias proteínas como alvo de ligação e induzir diferentes efeitos biológicos. O avanço do conhecimento e as recentes descobertas sobre os diferentes aspectos das sFLA $_{2}$ demonstram a relevância destas enzimas em respostas celulares e imunológicas e estimulam novos estudos para o esclarecimento de seus mecanismos de ação.

\subsection{Mastócitos: considerações gerais}

Estudos filogenéticos demonstraram que os mastócitos são células antigas, que podem ter sido originadas há mais de 550 milhões de anos, antes mesmo do aparecimento dos linfócitos (STEVENS; ADACHI, 2007; WONG et al., 2014). Estas células, inicialmentedescritaspor Paul Ehrlich, em 1878, com base na propriedade metacromática de seus grânulos, são caracterizadas como células secretoras multifuncionais, com numerosos grânulos que contém aminas biogênicas, proteoglicanos, citocinas e serinoproteases neutras (DA SILVA et al., 2014).

O processo ontogenético dos mastócitos ainda não foi completamente elucidado. Contudo, sabe-se que estas células, assim como os demais leucócitos, originam-se de precursores hematopoiéticos pluripotentes e agranularese expressam o fenótipo CD13 ${ }^{+}$, 


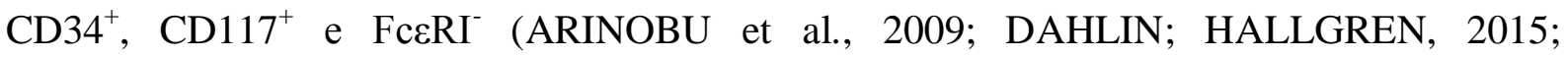
GILFILLAN; TKACZYK, 2006; RIBATTI; CRIVELLATO, 2014). Devido à ausência de grânulos, tem sido difícil identificar as células precursoras dos mastócitos, assim como a linhagem hematopoiética da qual se originam. As células precursoras dos mastócitos deixam a medula óssea ainda em estado indiferenciado e migram para o tecido periférico, onde permanecem neste estado até serem estimuladas por diferentes fatores (ARINOBU et al., 2005; CHEN et al., 2005; DAHLIN et al, 2013; DAHLIN; HALLGREN, 2015; JAMUR et al., 2005). As características destas células e sua permanência no tecido periférico são reguladas pelo microambiente e pela liberação de mediadores no local, como o SCF ("Stem Cell Factor") e a interleucina (IL)-3, secretados por fibroblastos, células estromais e endoteliais. Estas células são ativadas e recrutadas para outros tecidos, de acordo com as citocinas liberadas no local. Uma vez no tecido, as células precursorasfinalizam sua maturação e diferenciação (ARINOBU et al., 2009; CRIVELLATO et al., 2004; GALLI, 1993; GILFILLAN; TKACZYK, 2006).

Os mastócitos estão amplamente distribuídos no organismo e são encontrados, principalmente, no epitélio intestinal e pulmonar e no tecido conjuntivo, intimamente associados aos vasos sanguíneos, linfáticos e nervos (DA SILVA et al., 2014; DVORAK et al., 1983; LONGLEY et al., 1995; PEARCE, 1982). Estas células são identificadas como populações heterogêneas entre si, que apresentam características fenotípicas, morfológicas, bioquímicas e funcionais distintas, determinadas pelosfatores liberados no microambiente. Estas subpopulações apresentam diferenças no conteúdo de proteases intragranulares, de marcadores de superfície, de citocinas liberadas e na resposta a determinados estímulos (BRADDING et al., 1993; CRIVELLATO et al., 2004; DA SILVA et al., 2014; GALLI, 1990; METCALFE et al., 1997). Atualmente, são reconhecidas duas grandes subpopulações de mastócitos, classificadas de acordo com a sua distribuição anatômica e com as enzimas estocadas em seus grânulos, descritas a seguir: 1) mastócitos com triptase e quimase, encontrados nos tecidos conjuntivos, na pele, submucosa do estômago e do intestino, linfonodo, sinóvia e miocárdio. Essa subpopulação também possui carboxipeptidase A, catepsina $\mathrm{G}$ e a heparina, como principal proteoglicano estocado e 2) mastócitos com triptase, encontrados na mucosa intestinal e pulmonar (CRIVELLATO et al., 2004; GALLI; TSAI, 2008). Independentemente da subpopulação de mastócitos, a sua localização peculiar sugere que os mesmos estejam entre as primeiras células a iniciarem os processos imunológicos do organismo (CRIVELLATOet al., 2004; QURESHI; JAKSCHIK, 1988). 
Como mencionado anteriormente, os mastócitos são conhecidos como células efetoras locais, localizadas principalmente nas portas de entradas imunológicas e desempenham papel relevante em diversos contextos fisiológicos e patológicos, tais como no controle da homeostasia do hospedeiro, através da imunidade adquirida e inata, na inflamação e em reações alérgicas, infecções parasitárias e bacterianas, angiogênese, remodelagem tecidual, fibrose, proteção neuronal de doenças degenerativas, como a doença de Parkinson e na artrite reumatoide(CHURCH; LEVI-SCHAFFER, 1997; CRIVELLATO et al., 2004; DVORAK; KISSELL, 1991; GALLI et al., 1999; MEKORI; METCALFE, 2000; METZ; MAURER, 2007; OLSSON et al., 2001; RIBATTI et al., 1987; STASSEN et al., 2002; TUNCEL et al., 2005; WEISSLER et al., 2008).O avanço dos estudos sobre ao papel dos mastócitos em contextos biológicos tem revelado novas e surpreendentes funções destas células. Dentre algumas funções recentemente descritas para os mastócitos, pode-se citar a apresentação de antígenos, participação como célula adjuvante para a produção de anticorpos, na comunicação celular, na indução da tolerância imunológica e na osteoporose (DA SILVA et al., 2014; GHABLY et al., 2015; VOEHRINGER, 2013).

Os mastócitos expressam inúmeros receptores de reconhecimento de antígenos em sua superfície, dentre os quais os receptores de alta afinidade para IgE e IgG (FceRI, Fc $\gamma R I$, Fc $\gamma$ RII e Fc $\gamma$ RIII), receptores do complemento (C3aR, C5aR, CR3 e CR5) e os receptores do tipo Toll (TLR) 2, 3, 4, 5, 7 e 9 (ABRAHAM et al., 1997; GALLI; TSAI, 2008; GILFILLAN; TKACZYK, 2006;). Além disso, estas células expressam uma vasta gama de moléculas de adesão e receptores para fatores quimiotáticos, para tirosina-quinases e uroquinases, o que favorece a sua distribuição nos tecidos e os processos de ativação, diferenciação, sobrevivência e função proangiogênica. Ainda, foram identificados, na superfície destas células, vários receptores para citocinas e outros mediadores como a triptase, o SCF, diversas interleucinas, prostanoides, leucotrienos, o fator de necrose tumoral (TNF)- $\alpha$, adenosina, canais de cálcio dependentes do estoque intracelular de cálcio (CRAC, " $\mathrm{Ca}^{2+}$ release activated $\mathrm{Ca}^{2+}$ channels") e os canais de cálcio tipo L (LTCC, "L-type $\mathrm{Ca}^{2+}$ channels")(ABRAHAM; AROCK, 1998; GALLI; NAKAE, 2003; MALAVIYA et al.,1999; MIGALOVICHSHEIKHET et al., 2012; STASSEN et al., 2002; SUPAJATURA et al., 2001; SUZUKI et al., 2010; WEISSLER et al., 2008).Determinados estímulos, ainda pouco estudados, como componentes de venenos animais(por exemplo, as fosfolipases $\mathrm{A}_{2}$ ), peptídeos desgranuladores e alguns medicamentos são capazes de induzir a liberação de mediadores dos mastócitos.Contudo, ainda não foram identificados os possíveis receptores de tais agentes. 
Os mastócitos são células que apresentam numerosas vesículas secretórias (VSs) citoplasmáticas, contendo diversos mediadores estocados. De maneira geral, dentre os mediadores estocados estão as aminas biogênicas, como a histamina e serotonina, proteoglicanos como a heparina, o sulfato de condroitina e a serglicina e proteases,como triptases, quimases e carboxipeptidases (AZOUZ et al., 2014; DA SILVA et al., 2014; MILLER; PEMBERTON, 2002; MOON et al., 2014). Estes compostos possuem diversas funções biológicas, relacionadas à inflamação, imunomodulação, hemostasia, remodelamento de matrix extracelular, recrutamento celular e angiogênese (LUNDEQUIST; PEJLER, 2011). Além disso, as vesículas secretoras apresentam características lisossomais, devido ao $\mathrm{pH}$ ácido, à presença de enzimas lisossomais, como a $\beta$-glucuronidase e a $\beta$-hexosaminidase (esta última conhecida como um marcador da desgranulação dos mastócitos) e ainda, marcadores específicos de membrana de lisossomos (JOHNSON et al., 1980; LAGUNOFF; RICKARD, 1983;SCHWARTZ; AUSTEN, 1980; SUÁREZ-QUIAN, 1987). Ainda, podem ser encontrados nas vesículas dos mastócitos, outra classe de substâncias, representada pelas citocinas, como o TNF- $\alpha$, as IL-4, -5 e -8, quimiocinas, como RANTES ("regulated on activation, normal T cell expressed and secreted"), eotaxina, MCP("Monocyte Chemotactic Protein")-1, -3 e -4, e fatores de crescimento, como o Fator Básico de Crescimento de Fibroblastos (bFGF), o SCF e o Fator de Crescimento Endotelial Vascular (VEGF, do inglês "Vascular endothelial growth factor") (DA SILVA et al., 2014; MOON et al., 2014). Recentemente, foi detectada a presença de caspase-3, enzimaticamente ativa, no interior das vesículas secretórias dos mastócitos e acredita-se que esta caspase esteja envolvida em outros processos biológicos além da morte celular (GARCIA-FAROLDI et al., 2013).

Além dos mediadores estocados, os mastócitos ativados podem sintetizar e liberar diversos mediadoresinflamatórios, como leucotrienos e prostaglandinas, o fator ativador de plaquetas, citocinas, como o TNF- $\alpha$, o SCF, IL-1, -3, -4, -6, -10, -12, -13, -17, interferon (IFN) tipo I e II, quimiocinas como a linfotaxina, a IL-8, a MCP-1 e as MIP ("Macrophage Inflammatory Protein")- $1 \alpha$ e $\beta$ e fatores de crescimento como SCF(ABRAHAM; MALAVIYA, 1997; AJUEBOR et al., 1999; DA SILVA et al., 2014; GALLI et al.,1991; METZ; MAURER, 2007; MOON et al., 2014; WEDEMEYER et al.,2000).

A ativação dos mastócitos pode ser iniciada por pelo menos duas vias distintas, mediadas, ou não, por anticorpos. A via dependente de anticorpos, também chamada de anafilática, é desencadeada quando um antígeno se liga a anticorpos da classe $\operatorname{IgE}$ ou IgG, previamente ligados a receptores específicos, na membrana dos mastócitos. A outra via pode ocorrer por ativação de receptores para patógenos, como os TLRs, ou de receptores para 
citocinas. Neste contexto, toxinas e peptídeos, de origem animal ou sintético, causam a ativação dos mastócitos e induzem a desgranulação dos mediadores estocados, bem como a liberação de mediadores recém sintetizados, como já mencionado anteriormente. A natureza do estímulo determina o perfil de mediadores a serem liberados, sejam eles estocados ou recém-sintetizados. De acordo com o perfil de mediadores liberados, os mastócitos podem direcionar respostas imunológicas distintas e propiciar um perfil pró ou anti-inflamatório e imunomodulador, positivo ou negativo (GALLI et al., 1999; GALLI; TSAI, 2008; GILFILLAN; TKACZYK, 2006; OSKERITZIAN, 2015; WEISSLER et al., 2008).

O processo de liberação de medidores pelos mastócitos ativados depende da ativação de vias de sinalização estímulo-específicas e este processo foi melhor caracterizado em modelos que mimetizam respostas alérgicas, via ligação do complexo antígeno-IgE-FcęR. Apesar de novas vias e proteínas de sinalização serem descritas frequentemente, de modo geral, a ativação dos receptores FceRI resulta na fosforilação das proteínas Syk, Lyn e Fyn, que estão acopladas à porção citoplasmática do receptor e estão envolvidas na modulação dos processos de desgranulação e ativação dos mastócitos. Essas proteínas ativam proteínas adaptadoras, como a LAT ("Linker of Activation of T Cells") e NTAL ("Non-T-Cell Activation Linker") que, por sua vez, ativam a fosfolipase C (FLC), gerando inositol trifosfato $\left(\mathrm{IP}_{3}\right)$ e diacilglicerol (DAG) e participam da liberação de cálcio intracelular e da ativação da proteína quinase C (PKC), respectivamente (DA SILVA et al., 2014;RIVERA; GILFILLAN, 2006; SIRAGANIAN, 2003). A proteína NTAL também ativa a PI3K ("Phosphatidylinositol4,5-biphosphate 3-kinase"), que contribui para o aumento dos níveis de $\mathrm{IP}_{3}$ e ativaçãoda fosfolipase D (FLD), acarretando o aumento do cálcio intracelular (KIM et al., 2008; METCALFE et al., 2009).Já a ativação da PKC contribui para a desgranulação dos mastócitos e pode modular a síntese de mediadores por essas células, por aumentar ou diminuir a atividade da fosfolipase $\mathrm{A}_{2}$ citosólica $\left(\mathrm{cFLA}_{2}\right.$ ) (CHANG et al., 1997; $\mathrm{CHO}$ et al., 2004; KLEMM; RULAND, 2006). A via da MAPK (ERK1/2, JNK) também contribui para a síntese de citocinas pelos mastócitos, via ativação de um importante fator de transcrição, relacionado à síntese de mediadores inflamatórios, o NF-אB (KAMINSKA, 2005).

Um panorama geral das vias de transdução de sinal envolvidas na desgranulação e síntese de mediadores em mastócitos ativados pode ser visualizado na Figura 2, a seguir. 


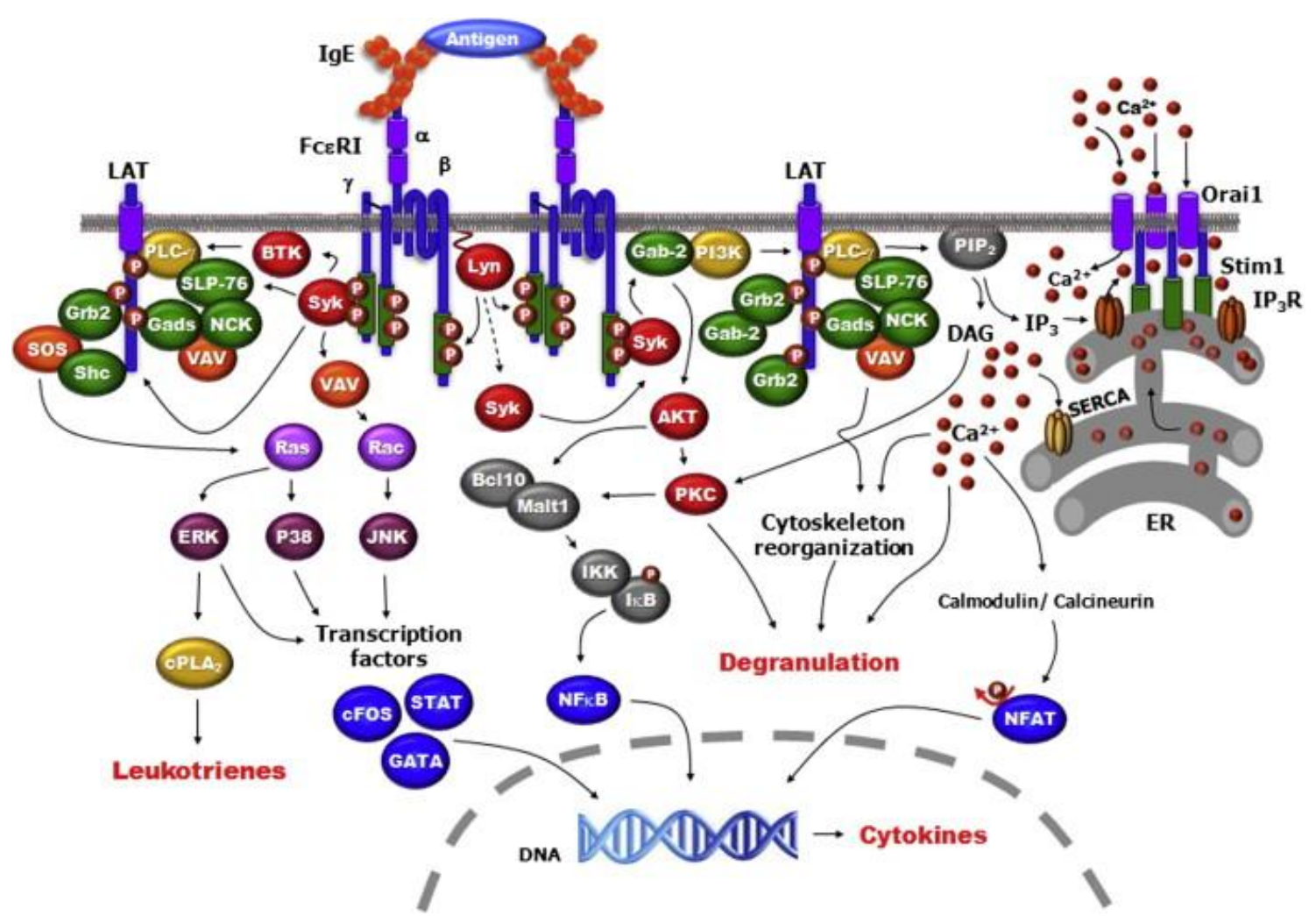

Figura 2. Ilustraçãocom principais moléculas e eventos envolvidos na ativação de mastócitos após ligação cruzada do antígeno com a IgE. A ativação dos receptores de IgE (FceRI) resulta a fosforilação das proteínas Lyn e Syk que, por sua vez, ativam a PI3K, que culmina na liberação de $\mathrm{IP}_{3}$ e aumento do cálcio intracelular proveniente do retículo endoplasmático. Este evento, dependente de STIM1, ativa os CRAC permitindo a entrada de cálcio extracelular. Ainda, esta ativação inicial do FceRI, acarreta a ativação da cPLA ${ }_{2}$, envolvida na síntese de mediadores lipídicos e indução da expressão de citocinas, via fatores de transcrição (Adaptado de SIRAGANIAN et al., 2010).

Diversas vias de sinalização nos mastócitos culminam na liberação de cálcio intracelular, um íon extremamente relevante para a fisiologia e para os processos de ativação e liberação de mediadores nestas células. Além disso, o cálcio ativa uma série de proteínas sinalizadoras, tais como a PKC e ascFLA 2 e sFLA 2 , que dependem do mesmo para exercerem seus efeitos biológicos (ASHMOLE; BRADDING, 2013; CISSEL et al., 1998; DI CAPITE; PAREKH, 2009).Existem duas principais fontes de cálcio que participam da ativação dos mastócitos. Uma delas é representada pelo cálcio intracelular, presente no retículo endoplasmático. Este estoque é mobilizado para o citoplasma quando o fosfatidilinositol bifosfato, um fosfolipídeo de membrana, é clivado gerando DAG e o inositol trifosfato $\left(\mathrm{IP}_{3}\right)$. Este último liga-se ao seu receptor $\left(\mathrm{IP}_{3} \mathrm{R}\right)$, expresso na membrana do retículo endoplasmático e acarreta o efluxo de cálcio desta organela para o citoplasma. Neste momento, uma proteína sensora localizada no lúmen do retículo, a STIM1 ("Stromal Interaction Molecule 1"), é liberada e transloca-se para os canais CRAC, sendo considerada como o primeiro sinal do retículo para ativar estes canais, presentes na membrana plasmática. O cálcio do retículo endoplasmático, liberado no citoplasma, liga-se a diversas proteínas para exercer seus efeitos 
biológicos.Contudo, este íon deve ser removido do citoplasma para não induzir toxicidade e a morte das células.Assim, inicia-se a recaptura do cálcio pelo retículo endoplasmático e pelas mitocôndrias. Consequentemente, com a diminuição da concentração citoplasmática do cálcio, mais moléculas STIM1 são liberadas e migram para os canais CRAC, representando o segundo sinal para a completa ativação dos CRAC. Estes canais, uma vez ativados, causam a entrada maciça de cálcio extracelular. Este novo aporte de cálcioconstitui um mecanismo importante para a manutenção do estado de ativação dos mastócitos (DI CAPITE, 2011; DI CAPITE; PAREKH, 2009;TAYLOR et al., 2009). Ainda, foi descrito que os mastócitos apresentam canais LTCC, que haviam sido descritos apenas em células excitatórias. Tais canais estão relacionados com o influxo de cálcio do meio extracelular e na exocitose de mediadores estocados nos mastócitos (SUZUKIet al., 2010; YOSHIMARU et al., 2009). Apesar da relevância do cálcio em processos celulares, o envolvimento deste íon, em processos relacionados com a ativação e desgranulação dos mastócitos, induzidos por fosfolipases $\mathrm{A}_{2}$ secretadas, nunca foram avaliados.

Os estudos relacionados à desgranulação dos mastócitos por estímulos independentes de IgE são escassos. Dentre os agentes estimulatórios estudados estão o mastoparan (peptídeo extraído do veneno de vespa) eo composto 48/80 (um polímero sintético), ambos reconhecidos como desgranuladores de mastócitos. Até o momento, foi descrita uma ação direta destes compostos em proteínas G, presentes na face interna da membrana citoplasmática dos mastócitos (FERRY et al., 2002; SHEFLER et al., 2008). Os mastócitos expressam as quatro isoformas de proteínas $G\left(G_{\alpha i}, G_{\alpha q}, G_{\alpha s}\right.$ e $\left.G_{\alpha 11 / 12}\right)$, descritas até o momento. No entanto, as isoformas $\mathrm{G}_{\alpha \mathrm{i}}$ e $\mathrm{G}_{\alpha \mathrm{q}}$ são aquelas relacionadas à desgranulação e à ativação destas células. A ativação da $\mathrm{G}_{\alpha i}$ inibe a adenilciclase e induz a ativação da FLC e o aumento do cálcio intracelular, enquanto a $G_{\alpha q}$ causa a fosforilação da Btk, uma importante quinase envolvida na ativação da FLC e no aumento do cálcio intracelular (CHAHDI et al., 2004; GILFILLAN; RIVERA, 2009; KUEHN; GILFILLAN, 2007). Adicionalmente, ocorre a ativação das proteínas quinases PI3K, JAK/STAT, PKC e MAPK, além das fosfolipases $\mathrm{A}_{2} \mathrm{e}$ D (KALESNIKOFF; GALLI, 2008).

O processo de desgranulação dos mastócitos ainda não foi completamente esclarecido, contudo, sabe-se que estas células passam por uma série de alterações morfológicas, dentre os quais está a formação de balsas lipídicas ("lipid rafts"), que são microdomínios lipídicos na membrana plasmática (DAVEY et al., 2007; SILVEIRA E SOUZA et al., 2011). Após a ativação dos mastócitos, alguns contituintes lipídicos da membrana celular, como colesterol, esfingolipídeos (como a esfingomielina) e gangliosídeos, que estão associados a diversos 
receptores e proteínas sinalizadoras, agrupam-se em regiões específicas e propiciam uma sinalização intracelular mais intensa para a desgranulação e a síntese de mediadores inflamatórios (HOLOWKA et al., 2005; RIVERA et al., 2002; SILVEIRA E SOUZA et al., 2011; SZÖOR et al., 2010).

A desgranulação dos mediadores estocados pelos mastócitos, de maneira geral, pode ocorrer por dois processos distintos: a anafilática e a lenta. A desgranulação anafilática é o processo mais estudado e pode ocorrer alguns minutos após a ativação dos mastócitos. Neste caso, após a estimulação das células, uma rede complexa de sinalização intracelular é ativada, acarretando o aumento de cálcio citoplasmático e fusão das diversas vesículas contendo os mediadores estocados e, posteriormente, a fusão destas vesículas com a membrana celular, liberando todo o conteúdo granular (DA SILVA et al., 2014). Todo este processo é dependente não somente do cálcio, mas também do citoesqueleto e de um conjunto de proteínas específicas presentes na face interna da membrana plasmática e nas membranas das vesículas citoplasmáticas dos mastócitos. As principais proteínas envolvidas com este processo são as SNAREs ("soluble N-ethylmaleimidesensitive factor attachment protein receptors"), encontradas na face interna da membrana celular, e as VAMPs ("vesicleassociated membrane proteins"), presentes nas vesículas citoplasmáticas. No seu estado basal, estas proteínas impedem a fusão das vesículas secretoras entre si e com a membrana celular. Contudo, quando os mastócitos são ativados e a concentração de cálcio citoplasmático aumenta, este íon liga-se à SNAREs e VAMPs. Estas últimas se aproximam e acarretam a fusão das vesículas citoplasmáticas de modo similar a um "ziper". Este mesmo processo ocorre na fusão das vesículas com a membrana plasmática (BLANK, 2002; GUO et al., 1998; LORENTZ et al., 2012; WOSKA; GILLESPIE, 2012; YANG et al., 2013). A desgranulação lenta (ou "piecemal", em inglês), por outro lado, é um processo muito pouco conhecido. Sabese que, diferentemente da anafilática, não ocorre fusão das vesículas secretoras, nem entre si e nem com a membrana celular. A desgranulação ocorre pela passagem dos mediadores pelas membranas das vesículas e da célula. Ainda não foram descritos os mecanismos envolvidos neste tipo de desgranulação,porém, sabe-se que ela é dependente do estímulo e está relacionada a doenças crônicas, como a artrite e o câncer (BENOIST; MATHIS, 2002; DVORAK, 2005; NIGROVIC; LEE, 2007; RIBATTI et al., 2004). Além disso, evidências da literatura demonstram que os mastócitos podem apresentar sistemas específicos para a liberação seletiva de mediadores,que dependem do contexto biológico. Neste sentido, foi demonstrado que a IL-1 $\beta$ induziu a síntese e liberação de óxido nítrico, a partir de mastócitos isolados, mas não induziu a liberação do PAF etambém não afetou a desgranulação destas 
células (HOGABOAM et al., 1993). Este processo não foi esclarecido até o momento (KRAEUTER KOPS et al., 1990; OLIVER et al., 1992;THEOHARIDES et al., 1982). Parte do conhecimento, relacionado às alterações morfológicas durante os processos de desgranulação, foram obtidos por estudos de morfologia ultraestrutural, a partir da microscopia eletrônica de transmissão (TEM). Esta técnica permitiu identificar a fusão de grânulos entre si e com a membrana plasmática, os diferentes padrões de conteúdo granular e o esvaziamento gradual do conteúdo vesicular sem o processo de fusão das membranas.

Como mencionado anteriormente, a desgranulação de mastócitos ativados por estímulos independentes de IgE não é bem conhecida. Com relação aos efeitos de componentes dos venenos de serpentes sobre a desgranulação e outros aspectos da biologia dos mastócitos, os estudos são ainda mais escassos. De modo geral, os dados da literatura limitam-se a relatar a capacidade das $\mathrm{FLA}_{2}$ de serpentes, em especial aquelas do gênero Bothops, desgranularem mastócitos mesentéricos e a contribuição destas células para o edema local induzido por essas enzimas (KANASHIRO et al., 2002; LANDUCCI et al., 1998, 2000). Além destes, recentemente, foi demonstrado que duas isoformas de $\mathrm{sFLA}_{2}$, do veneno da serpente asiática Protobothrops mucrosquamatus, as quais contém uma asparagina ou uma arginina na posição 49, induziram a desgranulação dos mastócitos, a formação de edema eo recrutamento e acúmulo destas células no local da sua injeção. Este efeito foi dependente da histamina, do PAF e das moléculas de adesão ICAM-1 ("Intercellular Adhesion Molecule-1" ou CD57), CD18 e da CD11a (WEI et al., 2009, 2010a, 2010b, 2013). Estes relatos estimulam estudos sobre a ação das sFLA $_{2}$ de serpentes em diferentes aspectos da biologia dos mastócitos. Neste sentido, até onde pode ser verificado, não há dados da literatura relacionados aos mecanismos que resultam na desgranulação dos mastócitos induzida por $\mathrm{sFLA}_{2} \mathrm{~s}$ ofídicas.

A linhagem de mastócitos RBL-2H3 ("Rat Basophilic Leukemia"), foi escolhida no presenteestudo pelo seu rápido crescimento celular, fácil manutenção e por ser considerada um excelente modelo experimental para avaliação de diversos aspectos funcionais, dentre eles, a sinalização intracelular (FUNABA et al., 2003; GILFILLAN; TKACZYK, 2006; IKAWATI et al., 2001; ORTEGA et al., 2003; RASHID et al., 2012). Estas células foram obtidas a partir de células leucêmicas, coletadas de ratos injetados com o $\beta$-cloretinamina, um composto químico carcinogênico (BARSUMIAN et al., 1981; SIRAGANIAN et al., 1975). Dentre os vários aspectos que fizeram com que a RBL-2H3 fosse amplamente utilizada em estudos de sinalização intracelular, está o fato de que estas células, quando ativadas pela ligação IgE/antígeno, apresentam uma resposta muito semelhante àquela observada em 
mastócitos primários, inclusive no que se refere aos mecanismos de desgranulação (BARSUMIAN et al.,1981; FUNABA et al., 2003; PASSANTE et al., 2009). Além disso, estas células são capazes de expressar genes exógenos transfectados e, por isso, esta linhagem celular está sendo vista como um modelo de grande potencial para estudos de pesquisa clínica(BLANK; VARIN-BLANK, 2004).

A partir das informações descritas e considerando que as fosfolipases $A_{2}$ são abundantes nos venenos botrópicos e induzem a desgranulação dos mastócitos, estudos detalhados que investiguem os mecanismos moleculares envolvidos nestes efeitos revestem-se de importância. Além disso, devido a homologia estrutural e funcional das fosfolipases $\mathrm{A}_{2}$ ofídicas, com as $\mathrm{sFLA}_{2} \mathrm{~s}$ de mamíferos, ambas do grupo IIA, este estudo poderá favorecer subsídios importantes para o conhecimento das ações das $\mathrm{sFLA}_{2} \mathrm{~S}$ envolvidas em doenças de origem inflamatória, em humanos, nas quais os mastócitos são elementos relevantes. 


\section{OBJETIVOS}

Este projeto teve por objetivo avaliar os efeitos da MT-I, uma fosfolipase $\mathrm{A}_{2}$ Asp49 do veneno da serpente Bothrops asper, em mastócitos em cultura, abordando diferentes aspectos da sua ativação, com ênfase na desgranulação e nas vias de sinalização envolvidas neste efeito.

De modo específico, o efeito da MT-I foi avaliado na:

1. desgranulação dos mastócitos, quanto à:

- contribuição da atividade catalítica;

- participação das proteínas PI3K, p38 ${ }^{\mathrm{MAPK}}, \mathrm{PKC}, \mathrm{ERK} 1 / 2, \mathrm{PTK}, \mathrm{Junk}, \mathrm{G} \alpha_{\mathrm{i}}, \mathrm{G} \alpha_{\mathrm{q}}$, das fosfolipases D, C e $\mathrm{A}_{2}$ intracelulares (citosólica e independente de cálcio) além dos canais de cálcio intracelular $\left(\mathrm{IP}_{3} \mathrm{R}\right)$ e extracelular (LTCC e CRAC).

2. ativação dos mastócitos, com relação à:

- liberação de $\mathrm{PGE}_{2}$;

- expressão gênica das citocinas TNF- $\alpha$, IL-1, IL-6, IL-4, IL-5 e IL-13;

3. alteração morfológica ultraestrutural. 


\section{MATERIAL E MÉTODOS}

3.1 Miotoxinas (MT)-I e -II e o veneno de Bothrops asper. O veneno da serpente Bothops asper (VBa) foi coletado de um "pool" de mais de 40 espécimes adultos coletados na Costa Rica e mantidos no serpentário do Instituto Clodomiro Picado. O veneno coletado foi liofilizado e estocado a $-20{ }^{\circ} \mathrm{C}$ até o momento de sua utilização. As Miotoxinas-I e -II, fosfolipases $\mathrm{A}_{2}$ secretadas, do grupo II-A, de peso molecular de 14,1 e $14 \mathrm{kDa}$, respectivamente, foram isoladas a partir do $\mathrm{VBa}$, da Costa Rica, e purificadas por cromatografia líquida de alta eficiência (HPLC) de troca iônica, em coluna de Carboximetileter-Sephadex C-25 (GUTIÉRREZ et al., 1984; LOMONTE; GUTIÉRREZ, 1989), seguida por cromatografia de fase reversa utilizando uma coluna semi-preparativa (10 mm diâmetro x $250 \mathrm{~mm}$ comprimento; Vydac, Columbia, MD, EUA), eluídas a $2.0 \mathrm{~mL} / \mathrm{min}$, com gradiente de 0 a $70 \%$ de acetonitrila, contendo $0,1 \%$ de ácido trifluoroacético, por 30 minutos, utilizando um Agilent 1200 (Agilent Technologies, Santa Clara, CA, EUA) monitorado a $215 \mathrm{~nm}$. A homogeneidade das miotoxinas foi demonstrada por HPLC e a pureza confirmada por eletroforese em gel de poliacrilamida a 12\%. As toxinas foram liofilizadas e estocadas a $-20{ }^{\circ} \mathrm{C}$ até o momento da sua utilização. O VBa e as miotoxinas foram fornecidos pelos Drs. José Maria Gutiérrez e Bruno Lomonte (Instituto Clodomiro Picado - Universidade da Costa Rica, Costa Rica). Abaixo encontra-se o cromatograma representativo do isolamento das miotoxinas do veneno da serpente Bothrops asper.

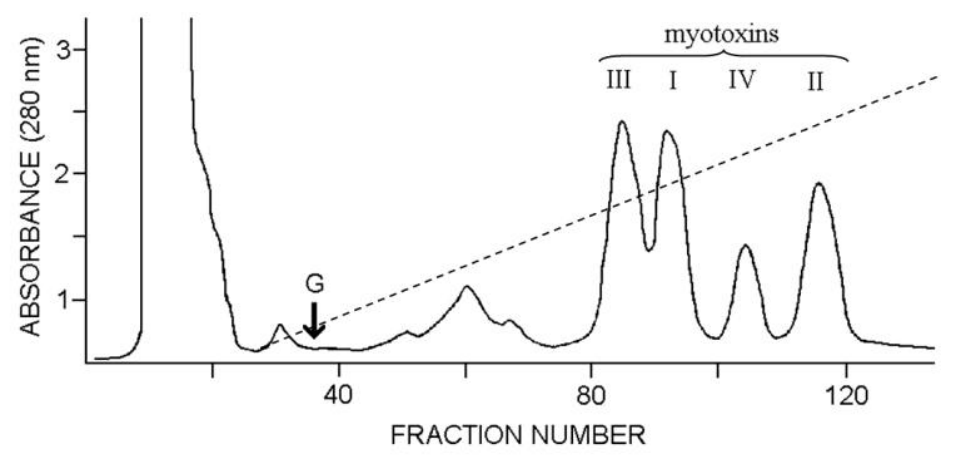

Figura 3. Cromatograma representativo das miotoxinas isoladas do veneno de B. asper. As amostras foram eluidas da coluna de CM-sephadex, no comprimento de onda de $215 \mathrm{~nm}$, como descrito acima (LOMONTE; GUTIÉRREZ, 1989, modificado pelos autores).

3.2 Cultivo de mastócitos murinos da linhagem RBL-2H3. Mastócitos de ratos, da linhagem transformada "Rat Basophilic Lineage" (RBL)-2H3, foram gentilmente cedidos pela Dra. Eliana Faquim de Lima Mauro (Instituto Butantan) e pelas Dras. Constance Oliver e Maria Célia Jamur (Faculdade de Medicina - USP Ribeirão). Inicialmente, estas células 
foram expandidas para 5 frascos de cultura de $175 \mathrm{~cm}^{2}$ e, após o $4^{\circ}$ subcultivo, as células foram congeladas em soro fetal bovino (SFB, Gibco-Life Technologies), contendo 5\% de dimetil sulfóxido (DMSO, Sigma-Aldrich) em um total de $10^{6}$ células por criotubo. Estes criotubos foram mantidos em nitrogênio líquido até o momento de sua utilização. Após o descongelamento, as células foram cultivadas em frascos de cultura para crescimento celular, de $25 \mathrm{~mm}^{2}$ (Sarstedt) ou de $150 \mathrm{~mm}^{2}$ (exclusivamente para experimentos de expressão gênica e proteica), em meio Eagle modificado por Dulbecco (DMEM - Gibco-Life Technologies) completo, suplementado com 15\% de soro fetal bovino (SFB) (Gibco-Life Technologies), 100 $\mathrm{U} / \mathrm{mL}$ de penicilina, $100 \mathrm{mg} / \mathrm{mL}$ de estreptomicina e $0,25 \mathrm{mg} / \mathrm{mL}$ de anfotericina $\mathrm{B}$ (GibcoLife Technologies), como descrito na literatura (BASCIANOet al., 1986; MORITA; SIRAGANIAN, 1981; PIERINIet al., 1996). Os mastócitos foram mantidos em incubadora, sob atmosfera úmida, a $5 \%$ de dióxido de carbono $\left(\mathrm{CO}_{2}\right)$ e a $37^{\circ} \mathrm{C}$, até a sua utilização.

\subsection{Subcultivo e plaqueamento dos mastócitos: Após os mastócitos atingirem} aproximadamente $80 \%$ de confluência, o meio de cultura foi retirado das garrafas e as células foram lavadas com $3 \mathrm{~mL}$ de tampão fosfato salina (PBS) do tipo II estéril ( $\mathrm{NaCl} 125 \mathrm{mM}$, $\mathrm{Na}_{2} \mathrm{HBO}_{4} 2 \mathrm{mM}, \mathrm{NaH}_{2} \mathrm{PO}_{4}$. $1 \mathrm{H}_{2} \mathrm{O} 2 \mathrm{mM}, \mathrm{KCl} 5 \mathrm{mM}, \mathrm{CaCl}_{2}$ 1,4 mM), pH 7,2. Após leve agitação das garrafas, o PBS foi retirado e foi adicionada solução de tripsina, contendo ácido etilenodiamino tetra-acético (EDTA, 0,537 mM), em volume de 2,5 mL/garrafa. As garrafas foram mantidas em incubadas (a $5 \%$ de $\mathrm{CO}_{2}$ e $37{ }^{\circ} \mathrm{C}$ ) por 7 minutos. Após este período, as garrafas foram retiradas da incubadora e, quando necessário, as garrafas receberam batidas suaves para o completo descolamento das células. Em seguida, foram adicionados $2,5 \mathrm{~mL}$ de DMEM, suplementado com $15 \%$ de SFB e as células foram passadas para tubos cônicos estéreis. Uma alíquota de $20 \mu \mathrm{L}$ das células foi coletada e solubilizada em azul de tripan (1:1) para contagem do número de células viáveis em câmeras de Neubauer. Os tubos contendo as células foram centrifugados a $129 \mathrm{~g}$ por 6 minutos. O sobrenadante foi descartado e as células foram ressuspendidas em $1 \mathrm{~mL}$ de DMEM sem vermelho fenol (Cambrex/Lonza) suplementado com $2 \mathrm{mM}$ de L-glutamina (Amresco). Uma alíquota das células foi adicionada a frascos de cultura contendo DMEM completo, para a manutenção das células. Outra alíquota das células foi diluída em DMEM, sem vermelho fenol, suplementado com Lglutamina, em concentrações celulares apropriadas para cada ensaio e colocadas em microplacas de 96 poços (para ensaios de desgranulação e dosagem de mediadores) ou de 6 poços (para ensaios de expressão gênica e proteica). As garrafas e as microplacas foram incubadas em estufa para cultura celular $\left(5 \%\right.$ de $\mathrm{CO}_{2}$ e $\left.37^{\circ} \mathrm{C}\right)$ até a sua utilização. 


\subsection{Ensaios de citotoxicidade em células RBL-2H3}

3.4.1 Avaliação da atividade mitocondrial: A toxicidade celular de diferentes concentrações da MT-I, da MT-II, do veneno de B. asper, dos inibidores ou de seus veículos sobre os mastócitos foi avaliada por meio da redução do sal de tetrazolium e formação do formazan (MOSMANN, 1983). Os mastócitos (6×104 células/poço) foram plaqueados de acordo com o descrito no item 3.3. Após 18 horas do plaqueamento, as células foram lavadas com tampão Tyrode (137 mM de NaCl; 2,7 mM de KCl; $12 \mathrm{mM}$ de $\mathrm{NaHCO}_{3} ; 0,37 \mathrm{mM}$ de $\mathrm{NaH}_{2} \mathrm{PO}_{4} ; 0,1$ $\mathrm{mM}$ de $\mathrm{MgCl}_{2} ; 1,3 \mathrm{mM}$ de $\mathrm{CaCl}_{2}$ e $10 \mathrm{mM}$ de Hepes, 0,1\% de BSA e 0,01\% de gelatina de suíno, pH 7,3) e incubadas com diferentes concentrações da MT-I, dos inibidores farmacológicos (descritos no item 3.6) ou dos respectivos veículos. Decorridos determinados períodos de tempo, as microplacas foram centrifugadas a $99 \mathrm{~g}$ por 5 minutos. O sobrenadante foi coletado para dosagens da Lactato Desidrogenase (LDH) (descrito a seguir) e foi adicionado às células $90 \mu \mathrm{L} /$ poço de uma solução de DMEM sem vermelho fenol suplementado com L-glutamina e $10 \mu \mathrm{L}$ de MTT previamente solubilizado em PBS, na concentração de $5 \mathrm{mg} / \mathrm{mL}$. As células foram incubadas em atmosfera úmida a $37^{\circ} \mathrm{C}$ e a $5 \%$ de $\mathrm{CO}_{2}$ por 3 horas. Para a dissolução dos cristais de formazan, oriundos da redução do sal de tetrazolium pelas células metabolicamente viáveis, foram adicionados $100 \mu \mathrm{L}$ de DMSO em cada poço. Após 30 minutos de agitação das microplacas, foi efetuada a leitura a $540 \mathrm{~nm}$ em espectrofotômetro (Labsystem Multiscan®) para determinação da densidade óptica (D.O.). Todos os valores foram analisados estatisticamente, conforme descrito no item 3.11.

3.4.2 Avaliacão da integridade da membrana celular: Este parâmetro foi avaliado pela determinação da atividade enzimática da Lactato Desidrogenase (LDH), presente nos sobrenadantes da cultura. Após incubação das células com a MT-I, a MT-II ou com o veneno de B. asper, em diferentes concentrações, ou com Tyrode (controle), nos diferentes períodos de tempo, uma alíquota de $30 \mu \mathrm{l}$ dos sobrenadantes dos mastócitos foi adicionado a uma microplaca de 96 poços contendo $170 \mu \mathrm{L}$ do substrato $(\mathrm{NaCl} 200 \mathrm{mM}$, NADH 0,2 $\mathrm{mM}$ e piruvato 1,6 mM) preparado em tampão fosfato $(\mathrm{pH} \mathrm{7,4).} \mathrm{As} \mathrm{amostras} \mathrm{foram} \mathrm{incubadas} \mathrm{a} 37$ ${ }^{\circ} \mathrm{C}$ e a D.O. das amostras foi determinada em espectrofotômetro com comprimento de onda de $340 \mathrm{~nm}$ (LabsystemMultiscan ${ }^{\circledR}$ ). Os resultados foram calculados pelo decréscimo da D.O., resultante da oxidação do NADH e a concentração final de NADH das amostras foi determinada a partir da interpolação das D.O. das amostras em uma curva de concentração de um padrão de $\mathrm{NADH}$. Os valores foram expressos em mmoles de NADH/minuto. 
3.5 Desgranulação de mastócitos: A desgranulação dos mastócitos foi avaliada pela dosagem da enzima $\beta$-hexosaminidase, uma enzima abundante nos grânulos dos mastócitos e reconhecidacomo um marcador da desgranulação destas células (HOHMAN; DRESKIN, 2001). Após o subcultivo, os mastócitos $\left(6 \times 10^{4}\right.$ células/poço) foram incubados em microplacas de 96 poços por 18 horas, como descrito no item 3.3. Após este período, os poços contendo os mastócitos aderidos foram lavados duas vezes com tampão Tyrode $(\mathrm{pH} 7,3)$ para remoção do meio de cultura e dos "debris" celulares. Em seguida, as células foram incubadas com tampão Tyrode (controle) ou com a MT-I, por diferentes períodos de tempo (de 30 minutos até 6 horas). Como controle positivo, foi utilizado o Ionóforo de cálcio A-23187 (Sigma-Aldrich), previamente solubilizado em DMSO na concentração de estoque e, posteriormente, diluído em Tyrode na concentração de uso $(1 \mu \mathrm{M})$. Após a incubação, as microplacas foram centrifugadas a $99 \mathrm{~g}$ por 5 minutos. O sobrenadante foi separado para dosagem da $\beta$-hexosaminidase liberada enquanto as células aderidas foram lisadas pela adição de solução de Tyrode + Triton X-100 (1\%), por 5 minutos. O lisado celular foi utilizado para a determinação da concentração de $\beta$-hexosaminidase residual. Alíquotas do sobrenadante e do lisado celular, em volume de $25 \mu \mathrm{L}$, foram incubados com o mesmo volume do substrato p-nitrofenil-N-acetil- $\beta$-D-glucosamina (NAG, $8 \mathrm{mM}$ ) solubilizado em tampão citrato de sódioácido cítrico $(\mathrm{pH} 4,5)$ por 30 minutos, a $37^{\circ} \mathrm{C}$. A seguir, a reação foi parada e revelada pela adição de Solução de Glicina (0,4 M, pH 10). A quantificação da $\beta$-hexosaminidase do sobrenadante e a residual foi determinada pela leitura das amostras em espectrofotômetro a 420 nm e a liberação foi calculada de acordo com a fórmula abaixo:

$$
\% \text { liberação }=\frac{\text { DO do sobrenadante }}{\text { DO do sobrenadante }+ \text { DO extrato do lisado celular }} \times 100
$$

\subsection{Participação de proteínas sinalizadoras na desgranulação de mastócitos induzida}

pela MT-I: O envolvimento de importantes proteínas sinalizadoras na desgranulação de mastócitos foi avaliado pela utilização de inibidores farmacológicos específicos para cada uma das proteínas, conforme descrito na Tabela 1, a seguir. Os inibidores foram inicialmente solubilizados em DMSO e, posteriormente, diluídos em Tampão Tyrode, na concentração de uso. Os inibidores foram incubados com os mastócitos minutos antes da incubação com Tyrode (controle) ou com MT-I $(0,35 \mu \mathrm{M})$ durante 30 minutos. Em seguida, foi avaliada a desgranulação dos mastócitos. A desgranulação dos mastócitos incubados somente com os veículos dos inibidores ou somente com os inibidores e na ausência da MT-I foi realizada 
como controle experimental. Todos os protocolos referentes aos inibidores foram baseados em artigos da literatura que demonstraram a eficiência dos mesmos.

Tabela 1 - Inibidores farmacológicos utilizados para avaliar a participação de proteínas sinalizadoras e de receptores na desgranulação dos mastócitos ativados pela MT-I.

\begin{tabular}{|c|c|c|c|c|}
\hline Proteína & Inibidor & $\begin{array}{c}\text { Concentração } \\
(\mu \mathrm{M})\end{array}$ & $\begin{array}{l}\text { Tempo } \\
\text { (min) }\end{array}$ & REF. \\
\hline Gaq & $\begin{array}{c}\text { Toxina B de } \\
\text { Clostridium difficile }\end{array}$ & 2 e $3(\mathrm{ng} / \mathrm{mL})$ & 90 & $\begin{array}{l}\text { PREPENS et al., } \\
1996 .\end{array}$ \\
\hline Gai & $\begin{array}{c}\text { Toxina Pertussis } \\
\text { (PTX) }\end{array}$ & 10 e $100(\mathrm{ng} / \mathrm{mL})$ & 120 & $\begin{array}{l}\text { HIRAYAMA et } \\
\text { al., } 2010 .\end{array}$ \\
\hline $\begin{array}{l}\text { Fosfolipase } \mathbf{A}_{2} \text { indep. } \\
\text { cálcio }\left(\mathbf{i F L A}_{2}\right)\end{array}$ & $\begin{array}{l}\text { Bromoenol lactona } \\
\text { (BEL) }\end{array}$ & 10 & 30 & $\begin{array}{l}\text { LEIGUEZ et al., } \\
2011\end{array}$ \\
\hline $\begin{array}{c}\text { Fosfolipase } \mathbf{A}_{2} \\
\text { citosólica }\left(\mathbf{c F L A} \mathbf{A}_{2}\right)\end{array}$ & $\begin{array}{c}\text { cPLA }_{2} \text { inhibitor II } \\
\text { (ou Pyrrophenone, } \\
\text { Pyr-2) }\end{array}$ & 1 & 30 & $\begin{array}{l}\text { LEIGUEZ et al., } \\
2011\end{array}$ \\
\hline Fosfolipase C (FLC) & U73122 & 10 & 15 & $\begin{array}{l}\text { YANASE et al., } \\
2010 .\end{array}$ \\
\hline Fosfolipase D (FLD) & FIPI & 0,75 & 30 & $\begin{array}{c}\text { YANASE et al., } \\
2009 .\end{array}$ \\
\hline PI3K & Wortmanina & 0,1 & 15 & $\begin{array}{c}\text { PREPENS et al., } \\
1996 .\end{array}$ \\
\hline PKC & H-7 & 6 & 15 & $\begin{array}{l}\text { LEIGUEZ et al., } \\
2011\end{array}$ \\
\hline ERK1/2 & PD98059 & 25 & 30 & $\begin{array}{l}\text { LEIGUEZ et al., } \\
2011\end{array}$ \\
\hline $\mathbf{P 3 8}^{\text {MAPK }}$ & SB202190 & 5 & 30 & $\begin{array}{l}\text { LEIGUEZ et al., } \\
2011\end{array}$ \\
\hline Junk & JNK Inhibitor II & 20 & 30 & $\begin{array}{c}\text { GRIGAT et al., } \\
2007\end{array}$ \\
\hline PTK & Herbimicina A & 10 & 30 & $\begin{array}{l}\text { LEIGUEZ et al., } \\
2011\end{array}$ \\
\hline Receptores de $\mathrm{IP}_{3}$ & Xestospongina $\mathrm{C}$ & 6 & 5 & OKA et al., 2002. \\
\hline CRAC & YM-58483 & 1 & 30 & LAW et al., 2011. \\
\hline LTCC & Nifedipina & 1 & 30 & $\begin{array}{c}\text { SUZUKI et al., } \\
2010 .\end{array}$ \\
\hline
\end{tabular}

3.7 Expressão proteica da PI3K fosforilada: Os mastócitos ( $3 \times 10^{6}$ células/poço) foram adicionadosa microplacas CorningCostar de 6 poços por 18 horas. A seguir, os poços foram lavados duas vezes com meio de cultura DMEM e as células foram incubadas com o DMEM (controle), com a MT-I $(0,35 \mu \mathrm{M})$ ou com ionóforo de cálcio A-23187 (1 $\mu \mathrm{M}$, controle positivo) por 5 minutos a $37^{\circ} \mathrm{C}$. A seguir, os poços foram lavados duas vezes com PBS (pH 7,3) e as células foram lisadas pela adição de Tampão RIPA (Sigma Aldrich) contendo inibidor de protease ("Protease Inhibitor Cocktail" - Sigma Aldrich) e de fosfatase ("Phosphatase Inhibitor Cocktail Set III" - Calbiochem), ambos os inibidores utilizados na 
concentração de 1:100 (v/v). A partir desta etapa, as células foram mantidas em gelo para evitar a degradação protéica. As amostras foram submetidas a banho frio de ultrassom por 25 minutos e centrifugadas a 14 mil RPM, por 15 minutos a $4{ }^{\circ} \mathrm{C}$ para remoção de debris celulares. O sobrenadante foi transferido para microtubo contendo igual volume de tampão Laemmli (Dodecil Sulfato de Sódio a 20\%; glicerina; $\beta$-mercaptoetanol a 1 M; tampão Tris a 1 M, pH 6,8; azul de bromofenol 0,1\%) (LAEMMLI, 1970). As amostras foram aquecidas a $100{ }^{\circ} \mathrm{C}$ por 10 minutos e mantidas congeladas a $-80{ }^{\circ} \mathrm{C}$ até o momento de sua utilização. As amostras foram submetidas à separação por eletroforese em gel de poliacrilamida a 12\% (SDS-PAGE) sob voltagem constante de $100 \mathrm{~V}$. Posteriormente, as bandas protéicas foram transferidas, em sistema tamponado, para uma membrana de nitrocelulose (BioRad Laboratories), com uma voltagem de $90 \mathrm{~V}$, durante 90 minutos, a $4^{\circ} \mathrm{C}$. Os sítios inespecíficos da membrana de nitrocelulose foram bloqueados com uma solução de albumina bovina fração V (Sigma-Aldich) a 5\%, diluída em TBS (Tris-Buffered Saline) contendo 5\% de Tween-20, pH 7,4, durante 1 hora. Após a lavagem das membranas com TBS, foi adicionado o anticorpo policlonal anti-fosfo-PI3K p85 (Tyr458)/p55(Tyr199) (CellSignaling), na diluição de 1:1000 (v/v), por 18 horas, a $4^{\circ} \mathrm{C}$. Posteriormente, após uma série de lavagens com TBS, foi incubado o anticorpo secundário (anti-IgG de coelho, 1:2000, v/v), conjugado à peroxidase, durante 1 hora, em temperatura ambiente. Como controle do carregamento protéico, as membranas foram incubadas também com anticorpo monoclonal anti- $\beta$-actina (Sigma Aldrich), na diluição de 1:4000 (v/v), seguido pela incubação do anticorpo secundário contra a $\beta$-actina (anti-IgG de camundongo 1:2000). As membranas foram incubadas com solução luminol (Millipore) por 5 minutos e as bandas imunorreativas foram detectadas, fotografadas e quantificadas utilizando o sistema digital ImageQuant LAS 4000 mini (GE Healthcare). O peso molecular das bandas foi calculado a partir das mobilidades relativas de proteínas marcadoras de peso molecular (faixa: 29 a $205 \mathrm{kDa}$ ).

3.8 Determinação da concentração de prostaglandina (PG)E $\mathbf{E}_{2}$ : Os níveis de $\mathrm{PGE}_{2}$ liberada no sobrenadante de mastócitos incubados com a MT-I ou com o Tyrode (controle) foram mensurados por ensaio imunoenzimático (EIA), utilizando kits disponíveis comercialmente (Cayman, Co, USA), de acordo com as instruções do fabricante. Ao final da reação, a densidade óptica das amostras foi determinada a $412 \mathrm{~nm}$, em espectrofotômetro. Os valores obtidos foram convertidos em concentração em pg/mL, a partir da extrapolação dos dados utilizando a equação da reta de concentrações crescentes do padrão fornecido pelo fabricante. 
3.9 Expressão gênica de citocinas de perfil Th1/Th2: Os mastócitos ( $3 \times 10^{6}$ células/poço) foram adicionados em microplacas CorningCostar de 6 poços por 18 horas. A seguir, os poços foram lavados duas vezes com meio de cultura DMEM e as células foram incubadas com o DMEM (controle) ou com a MT-I $(0,35 \mu \mathrm{M})$ por 1,3 ou 6 horas. O ácido ribonucleico (RNA) total foi extraído com a utilização do RNeasy mini kit (Qiagen), de acordo com as instruções do fabricante. A concentração do RNA foi mensurada por espectrofotometria, com leitura a $260 \mathrm{~nm}$ e a pureza foi calculada pela relação $\mathrm{A}_{260} / \mathrm{A}_{280}$. Em seguida, o RNA foi convertido em ácido desoxirribonucleico codificante (cDNA) por reação de transcrição reversa. Para tanto, 1 $\mu \mathrm{g}$ de RNA foi incubado com $1 \mu \mathrm{L}$ de OligodTs $(0,05 \mu \mathrm{g} / \mu \mathrm{L}), 1 \mu \mathrm{L}$ de SuperScriptTM II Reverse Transcriptase e completado para $20 \mu \mathrm{L}$ com água tratada (DEPC). Em seguida, as amostras foram colocadas no termocicladorBio-Rad Gene CyclerTM por 10 minutos a $70^{\circ} \mathrm{C}$, 50 minutos a $42^{\circ} \mathrm{C}, 15$ minutos a $70{ }^{\circ} \mathrm{C}$ e 20 minutos a $37^{\circ} \mathrm{C}$. Para as reações em cadeia da Polimerase (PCR), o cDNA alvo foi amplificado utilizando-se $1 \mu \mathrm{L}$ da enzima Taq DNA polimerase (2,5 $\mathrm{U}), \mathrm{MgCl}_{2}(1,25 \mathrm{mM})$ e dNTPs $(0,2 \mathrm{mM})$. Os valores foram normalizados a partir do gene endógeno GAPDH a partir dos valores de $\mathrm{Ct}(\Delta \Delta \mathrm{Ct})$. A sequência dos “primers" específicos para cada citocina encontra-se na Tabela 2, a seguir. Todos os reagentes utilizados para o PCR quantitativo foram fornecidos pela Life Technologies.

\section{Tabela 2 - Sequência de "primers" utilizados para PCR quantitativo.}

\begin{tabular}{ccc} 
& \multicolumn{1}{c}{ Foward } & Reverse \\
IL-1 $\boldsymbol{\beta}$ & TCC TCT GCC AAG TCA GGT CT & GGT AAG TGG TTG CCT GTC AGA \\
TNF- $\boldsymbol{\alpha}$ & CGT CAG CCG ATT TGC CAT TTC & TGG GCT CAT ACC AGG GCT TGA G \\
IL-6 & CGA GCC CAC CAG GAA CGA AAG & CTG GCT GGA AGT CTC TTG CGG AG \\
$\mathbf{I L}-\mathbf{4}$ & GGT CTC AGC CCC CAC CTT GC & CCG TGG TGT TCC TTG TTG CCG T \\
$\mathbf{I L - 5}$ & GTT GAG GAG CAA TGA GAC GAT & GCC ACA CTT CTC TTT TTG TCC \\
$\mathbf{I L - 1 3}$ & AGG AGC TGA GCA ACA TCA CAC & CCA TAG CGG AAA AGT TGC TT \\
GAPDH & AAG AAG GTG GTG AAG CAG GC & TCC ACC ACC CTG TTG CTG TA \\
\hline
\end{tabular}

3.10 Análise ultraestrutural dos mastócitos incubados com a MT-I: Os mastócitos $\left(3 \times 10^{6}\right.$ células/poço) foram semeados em microplacas CorningCostar de 6 poços, por 18 horas, em DMEM sem SFB e sem vermelho fenol. A seguir, os poços foram lavados duas vezes com meio de cultura DMEM, sem SFB e sem vermelho fenol, e as células foram incubadas com o este mesmo DMEM (controle) ou com a MT-I $(0,35 \mu \mathrm{M})$ em atmosfera úmida, a $37^{\circ} \mathrm{C}$ e $5 \%$ de $\mathrm{CO}_{2}$, por 1 hora. Após a incubação, o sobrenadante foi removido e os poços lavados 2 vezes com PBS e as células foram fixadas com glutaraldeído a 2,5\%, diluído em tampão fosfato $0,1 \mathrm{M}, \mathrm{pH} 7,4$, contendo 3,5\% de sacarose, por 2 horas, à temperatura ambiente. Em 
seguida, as células foram cuidadosamente descoladas das microplacas utilizando rodinhos, transferidas para tubos de ensaio de vidro e centrifugadas a $130 x \mathrm{~g}$, por 6 minutos. As células foram lavadas 2 vezes com tampão fosfato e pós-fixadas com tetróxido de ósmio a 1\%, por 2 horas. As células foram centrifugadas para retirar o ósmio, ressuspendidas com tampão fosfato $(0,1 \mathrm{M})$ e mantidas em suspensão por 5 minutos, seguida por centrifugação e ressupensão em tampão fosfato. Este processo de lavagem foi realizado 3 vezes. As células foram desidratadas com concentrações crescentes de etanol (50 a $100 \%$ ), terminando em óxido de propileno. A seguir, as células foram embebidas em solução de óxido de propileno e resina Spurr, na diluição de 1:1 (v/v), por 18 horas. Em seguida, esta mistura foi substituída por resina pura e mantidas por 4 horas. Posteriormente, as amostras foram mantidas em estufa a $60{ }^{\circ} \mathrm{C}$, por 72 horas, para a polimerização da resina. Para localização da área onde se encontram as células, cortes semifinos, de $1 \mu \mathrm{M}$ de espessura, foram obtidos em ultramicrótomo Leica Ultracult UCT® e corados com uma solução aquosa de borato de sódio $1 \%$, preparada em solução aquosa de azul de toluidina 25\%, para observação ao microscópio de luz. Identificada a região, no mesmo micrótomo foram realizados cortes ultrafinos, prateados, de cerca de $60 \mathrm{~nm}$ de espessura. Estes cortes foram resgatados em telas de cobre e contrastados com acetato de uranila a $2 \%$, em água destilada, por 5 minutos, seguida por citrato de chumbo a $0,5 \%$, em água destilada, por 10 minutos. A análise do material foi realizada sob o microscópio eletrônico LEO 906E (Zeiss) utilizando o programa de captura de imagem - ITEM Olympus Soft Imaging Solutions GmbH (version ITEM_E_23082007) e uma câmera MegaView III. As imagens digitais do grupo controle e estimulado com MT-I foram submetidas a uma análise morfométrica, através da contagem do número de vesículas granulares presentes em todas as secções de células onde era possível identificar a presença do núcleo. Os parâmetros adotados para a contagem das vesículas foram baseados na presença de núcleo nos cortes das células, nas estruturas intracelulares circulares (vesículas granulares) que continham material elétrondenso e na presença de bicamada lipídica nestas estruturas vesiculares. Ainda, foram incluídas na amostragem pelo menos 30 secções celulares de cada grupo.

3.11 Análise estatística: Os valores expressos em porcentagem foram analisados estatisticamente após terem sido convertidos em arcoseno. Os dados foram representados como média \pm erro padrão da média (E.P.M.) e analisados pelo teste t-Student para comparação entre dois grupos ou por análise de variância (ANOVA) "1 way" para uma variável ou "2 way" para duas variáveis com correção de Bonferroni. Quando detectada 
diferença estatística significativa, foi aplicado o pós-teste de Tukey para comparações entre dois grupos. Em todas as análises, foi fixado o nível crítico igual ou menor que 5\% (p $\leq 0,05)$ com intervalo de confiança de $95 \%$. As análises estatísticas foram realizadas a partir do programa computacional GraphPad Prism versão 5. As análises estatísticas do presente estudo foram confirmadas pela estaticista Rosa Prisco, do Instituto de Ciências Biomédica (ICB) da Universidade de São Paulo (USP). 


\section{RESULTADOS}

Inicialmente, foram padronizadas as condições ideais para o estabelecimento das culturas de mastócitos da linhagem RBL-2H3 no laboratório e definiu-se pela realização dos ensaios com células entre a $5^{\circ}$ e $15^{\circ}$ passagem, com base na homogeneidade dos resultados obtidos nos ensaios de desgranulação.

A atividade enzimática da MT-I nativa e da MT-I BPB foi avaliada por estudos de cinética da degradação do substrato de lecitina de soja. Os resultados obtidos demonstraram que a MT-I nativa apresentava intensa atividade enzimática enquanto que a MT-I BPB teve uma redução expressiva da sua atividade catalítica (dados não demonstrados).

\subsection{Efeito da MT-I na viabilidade dos mastócitos em cultura}

Para avaliar os possíveis efeitos citotóxicos da MT-I sobre os mastócitos em cultura, foram realizados ensaios para a determinação da atividade mitocondrial, por meio da redução do brometo de 3-(4,5-dimetil-2-tiazolil)2,5-difenil-2H-tetrazolium (MTT) e para a avaliação da integridade da membrana celular, pela determinação da atividade da lactato desidrogenase (LDH) liberada no sobrenadante das culturas. Os mastócitos $\left(6 \times 10^{4}\right.$ células/poço) foram incubados com diferentes concentrações da MT-I ou com o Tyrode (controle) por 1 hora.

Como pode ser observado na Figura 4 (A e B), a MT-I, nas concentrações de 0,035 e 0,35 $\mu \mathrm{M}$, não alterou nenhum dos parâmetros avaliados, quando comparada ao controle basal (Tyrode). No entanto, na concentração de 3,5 $\mu \mathrm{M}$, a MT-I causou uma diminuição significativa da atividade mitocondrial, assim como um aumento sugnificativoda liberação da LDH. Para detalhar melhor as concentrações não citotóxicas da MT-I, foram avaliadas concentrações intermediárias da toxina (de 0,175 a 1,75 $\mu \mathrm{M})$. De acordo com a figura 4 (C e D), a MT-I, nas concentrações entre 0,175 e $0,875 \mu \mathrm{M}$, não alterou nenhum dos parâmetros avaliados. No entanto, a concentração de $1,75 \mu \mathrm{M}$ da MT-I causou alterações significativas em ambos os parâmetros testados. Nestes experimentos, uma solução de Tyrode, contendo Triton X-100 (10\%), foi utilizada como controle positivo. Ainda, a MT-I, nas concentrações de 0,035 a $0,875 \mu \mathrm{M}$, não causou nenhuma alteração dos parâmetros testados desde os 30 minutos até 6 horas de incubação com os mastócitos (dados não demonstrados). 


\section{LDH}

A

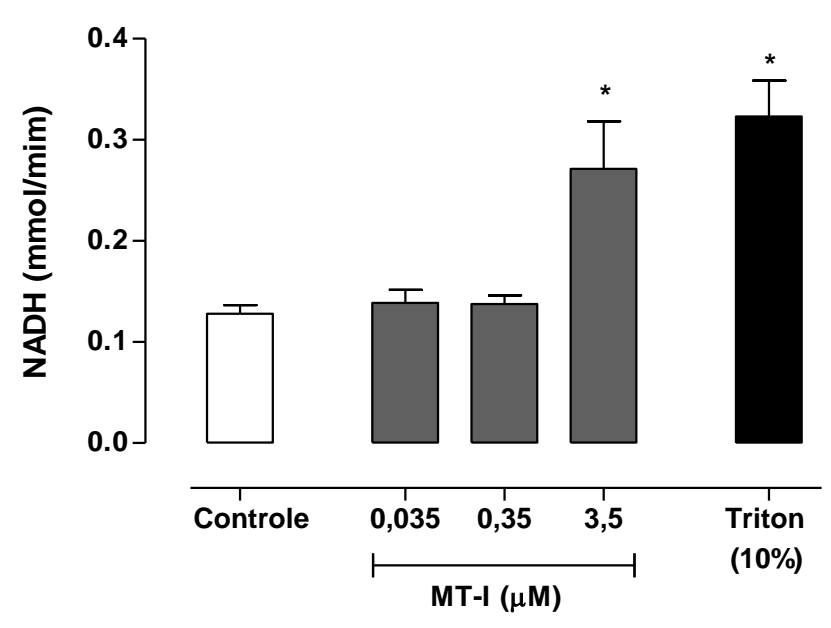

C

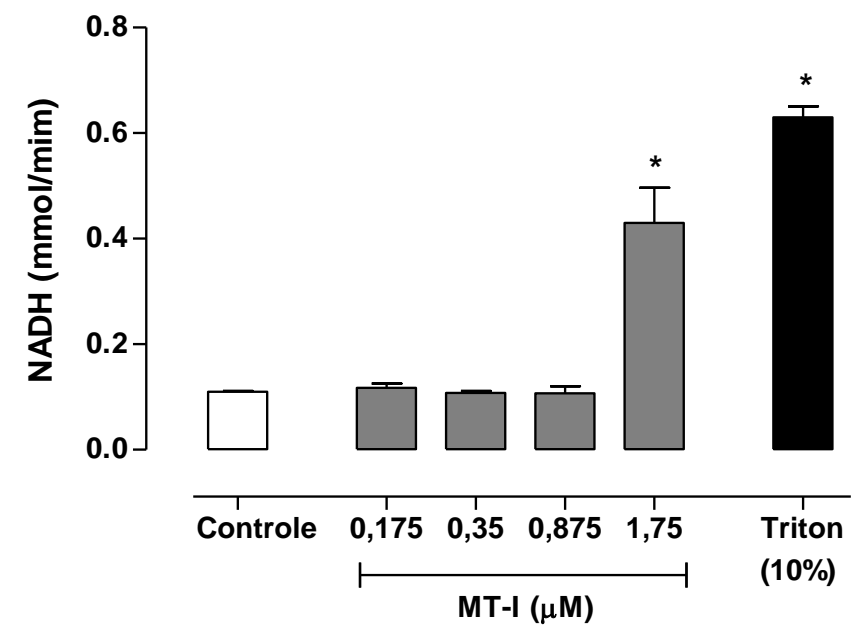

B

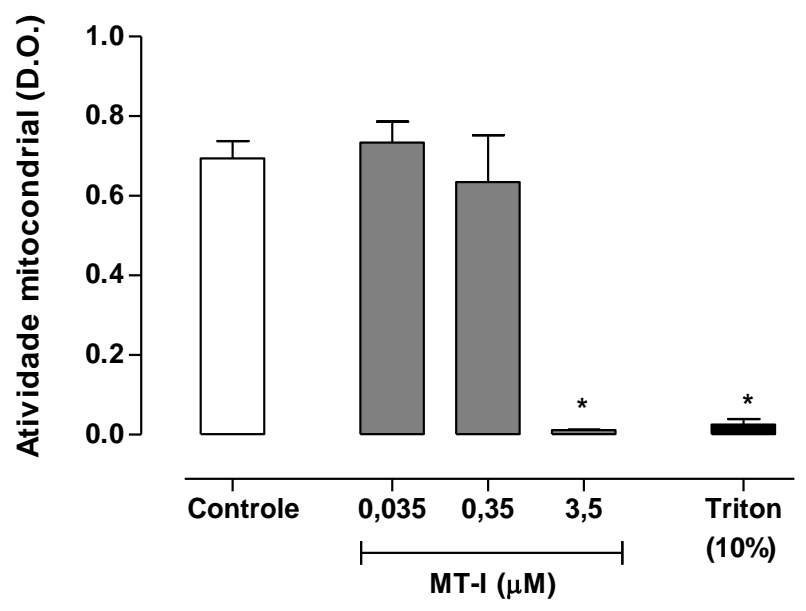

D

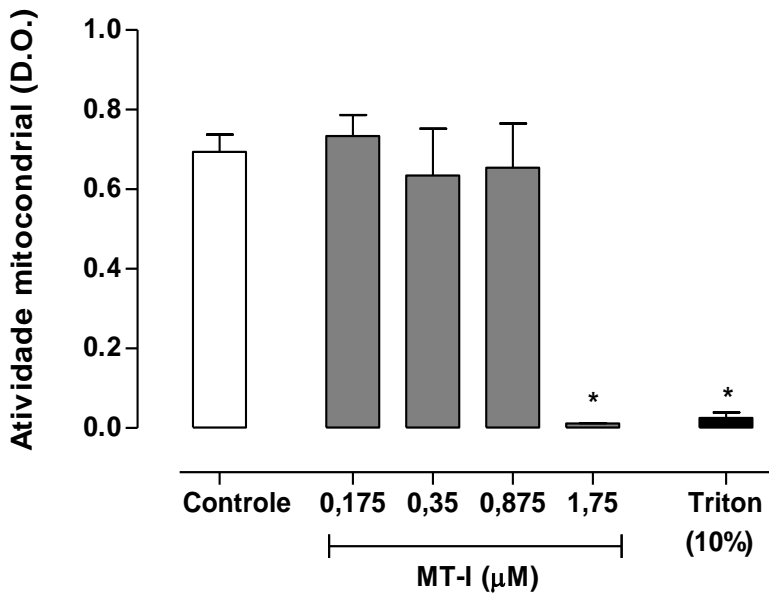

Figura 4. Efeito citotóxico de concentrações crescentes da MT-I em mastócitos em cultura. Os mastócitos $\left(6 \times 10^{4}\right.$ células/poço) foram incubados com concentrações crescentes da MT-I, com Triton X-100 a 10\% (controle positivo) ou com Tyrode (controle basal) por 1 hora, em atmosfera úmida, a $37{ }^{\circ} \mathrm{C}$ e com $5 \%$ de $\mathrm{CO}_{2}$. Após este período de tempo, foram avaliadas a liberação de LDH (A e C) e a atividade mitocondrial, pelo ensaio de MTT (B e D), como descrito em Material e Métodos. Cada barra representa a média \pm EPM de $n=3$ de 3 experimentos independentes. ${ }^{*} \mathrm{p}<0,05$ em relação ao controle (1-way ANOVA seguida por teste de Tukey). 


\subsection{Efeito da MT-I na desgranulação de mastócitos}

Para este estudo, os mastócitos $\left(6 \times 10^{4}\right.$ células/poço) foram incubados com concentrações crescentes e não citotóxicas da MT-I (0,07, 0,35 e 0,7 $\mu \mathrm{M})$, com o ionóforo de cálcio A23187 (ICa, $1 \mu \mathrm{M}$ ), como controle positivo, ou com o Tyrode (controle basal), por 1 hora. Após este período de tempo, a desgranulação foi avaliada pela determinação da atividade enzimática da $\beta$-hexosaminidase liberada no sobrenadante.

Conforme demonstrado na Figura 5, a MT-I, nas três concentrações testadas, causou um aumento na liberação de $\beta$-hexosaminidase (de aproximadamente 130\%), que foiestatisticamente significativo, se comparado ao controle basal (Tyrode). Não houve diferença na magnitude dos efeitos entre as diferentes concentrações da MT-I. A incubação com o ionóforo de cálcio A-23187 causou um aumento significativo da desgranulação dos mastócitos, quando comparado ao controle negativo e equivalente ao efeito da MT-I. Com base nestes resultados, a concentração de $0,35 \mu \mathrm{M}$ da MT-I foi selecionada para os experimentos subsequentes, por ser intermediária dentre as testadas.

Adicionalmente, como controle, foi avaliada a desgranulação dos mastócitos incubados com uma proteína não imunogênica, a albumina sérica bovina, nas concentrações de 0,35 e $0,7 \mu \mathrm{M}$, por até 6 horas e não houve diferença estatística em relação ao controle basal (dados não demonstrados).

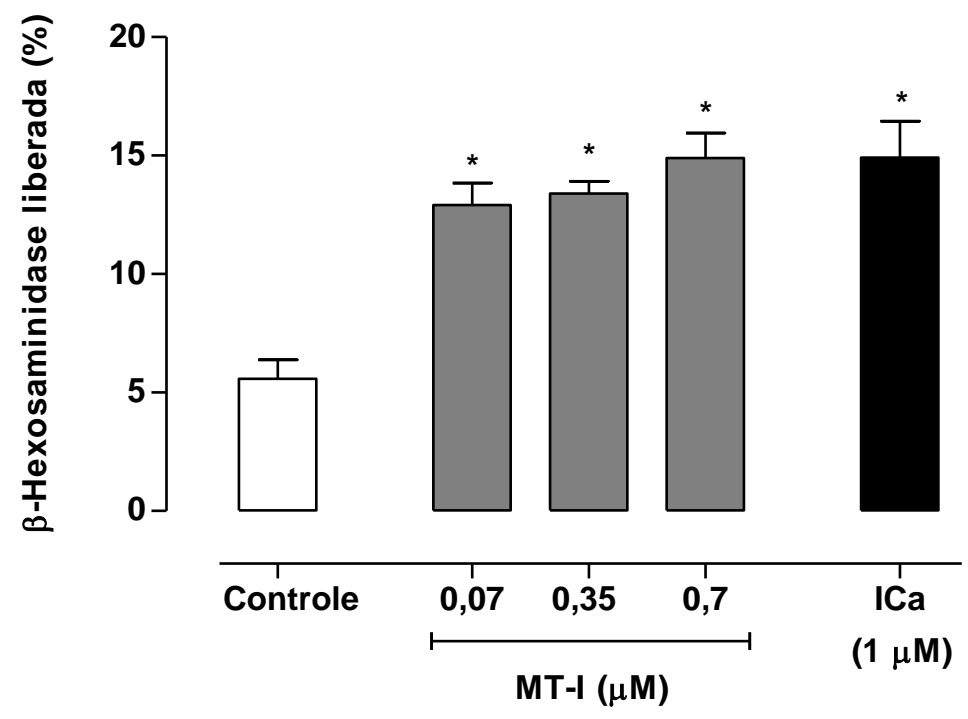

Figura 5. Desgranulação de mastócitos induzida por concentrações crescentes de MT-I. Os mastócitos $\left(6 \times 10^{4}\right.$ células/poço) foram incubados com concentrações da MT-I, com o ionóforo de cálcio A23187 (1 $\mu \mathrm{M}$,controle positivo) ou com o Tyrode (controle basal), por 1 hora. A desgranulação dos mastócitos foi avaliada pela determinação da liberação de $\beta$-hexosaminidase, como descrito em Material e Métodos. Cada barra representa a média \pm EPM de n=3 de 3 experimentos independentes. ${ }^{*} \mathrm{p}<0,05$ em relação ao controle (1-way ANOVA seguida por teste de Tukey). 


\subsection{Perfil temporal da desgranulação dos mastócitos induzida pela MT-I}

Para este estudo, os mastócitos foram incubados com a MT-I $(0,35 \mu \mathrm{M})$ ou com o Tyrode (controle) por 30 minutos, 3 e 6 horas. Como mostra a Figura 6, a MT-I causou um aumento significativo e crescente da desgranulação dos mastócitos em todos os períodos de tempo, quando comparada ao controle. A desgranulação dos mastócitos pela MT-I diferiu estatististicamente em todos os períodos de tempo avaliados.

Considerando que a desgranulação dos mastócitos é um evento rápido e que a MT-I induziu este efeito, de modo diferente do controle, aos 30 minutos, este período de tempo foi escolhido para os estudos subsequentes.

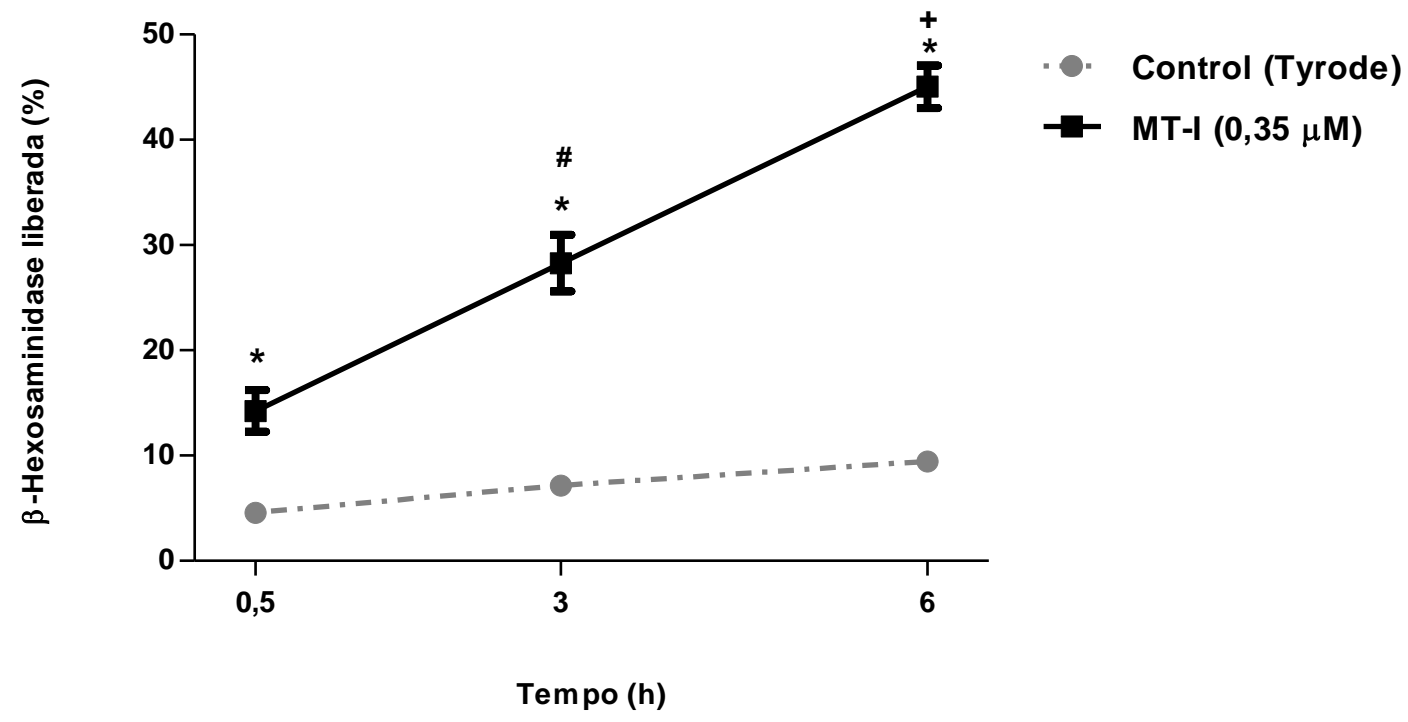

Figura 6. Cinética da desgranulação de mastócitos induzida pela MT-I em mastócitos em cultura. Os mastócitos $\left(6 \times 10^{4}\right.$ células/poço)foram incubados com a MT-I $(0,35 \mu \mathrm{M})$ ou com Tyrode (controle), por diferentes períodos de tempo. A desgranulação dos mastócitos foi avaliada pela determinação da liberação da $\beta$-hexosaminidase, como descrito em Material e Métodos. Cada barra representa a média \pm EPM de $n=3$ de 3 experimentos independentes. ${ }^{*} \mathrm{p}<0,05$ em relação ao controle; ${ }^{\#} \mathrm{p}<0,05$ em relação a MT-I 0,5 hora; ${ }^{+}$p<0,05 em relação a MT-I 3 horas (2-way ANOVA seguida por Tukey). 


\subsection{Importância da atividade enzimática da MT-I na desgranulação dos mastócitos}

Como mencionado na introdução, as fosfolipases $A_{2}$, de venenos de serpentes, podem apresentar atividade enzimática ou não, e esta característica pode repercutir no efeito biológico da mesma. Deste modo, foram analisados os efeitos da MT-I cataliticamente ativa (nativa) e da MT-I com a atividade enzimática inibida pela complexação com o composto alquilante brometo de p-bromofenacila (BPB).

Como pode ser observado na Figura 7-A, a MT-I nativa causou um aumento significativo na desgranulação dos mastócitos, como já esperado. De modo similar, a MTI/BPB causou um aumento na desgranulação dos mastócitos, que foi estatisticamente significante, se comparado ao controle basal. Porém, este efeito da MT-I BPB foi cerca de $50 \%$ menor do que o efeito causado pela MT-I nativa. Para confirmar estes resultados, foram utilizadas concentrações não citotóxicas da MT-II, uma sFLA 2 homóloga à MT-I, que possui uma lisina na posição 49, sendo destituída de atividade enzimática. Como pode ser visto na Figura 7-B, as menores concentrações da MT-II $(0,075$ e $0,35 \mu \mathrm{M})$ não induziram a desgranulação dos mastócitos, quando comparado ao controle basal (Tyrode). Na maior concentração, contudo, a MT-II causou um aumento significativo da desgranulação dos mastócitos, se comparado ao controle basal. Ainda, a magnitude deste efeito, nesta concentração, não diferiu daquele causado pela MT-I $(0,35 \mu \mathrm{M})$ 
A
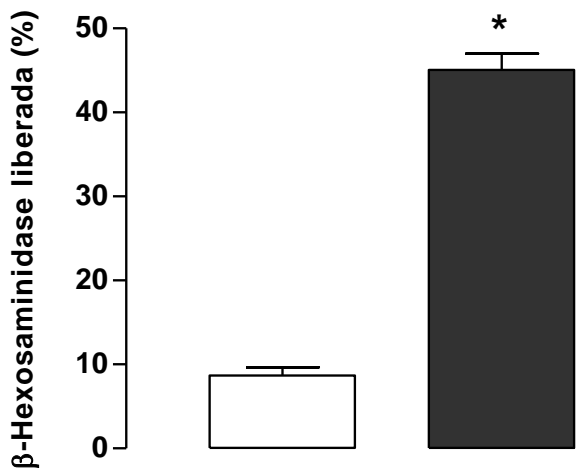

MT-I

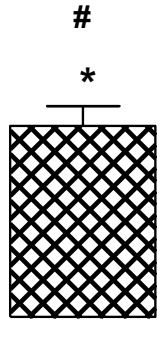

Controle

$$
\text { MT-I BpB }
$$

B

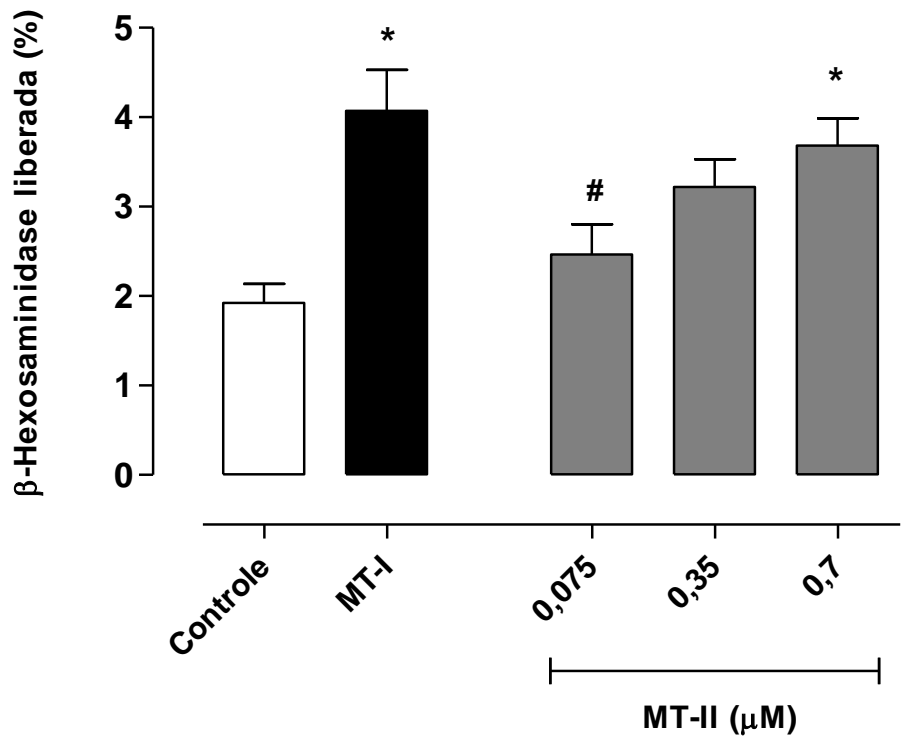

Figura 7. Efeito da MT-I enzimaticamente inativada e da MT-II na desgranulação de mastócitos em

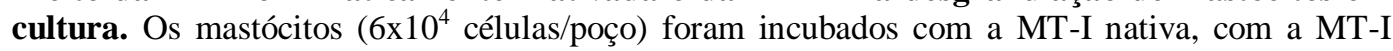
destituída de atividade enzimática (MT-I BPB), com a MT-II ou com Tyrode (controle negativo) por 30 minutos, em estufa de $\mathrm{CO}_{2}$ a $5 \%$ e a $37{ }^{\circ} \mathrm{C}$. A desgranulação dos mastócitos foi avaliada pela determinação da liberação da $\beta$-hexosaminidase, como descrito em Material e Métodos. Cada barra representa a média \pm EPM de $n=3$ de 3 experimentos independentes $* p<0,05$ em relação ao controle; ${ }^{\text {p }<0,05 ~ e m ~ r e l a c ̧ a ̃ o ~ a o ~ g r u p o ~ M T-I ~(1-w a y ~ A N O V A ~ s e g u i d a ~ p o r ~ t e s t e ~ d e ~ T u k e y) . ~}$ 


\subsection{Participação de proteínas quinases na desgranulação de mastócitos induzida pela MT-I}

Diversas proteínas quinases estão envolvidas na desgranulação dos mastócitos ativados por diferentes estímulos. Deste modo, avaliou-se o papel das proteínas p38 ${ }^{\mathrm{MAPK}}$, ERK1/2, PKC, PI3K, PTK e Junk na desgranulação dos mastócitosinduzida pela MT-I, utilizando inibidores seletivos para cada proteina de interesse, como descrito em Material e Métodos. Nenhum dos inibidores, utilizados isoladamente, nas concentrações e tempos estudados ou seus veículos, causaram alterações significativas da viabilidade celular e nem induziram a desgranulação dos mastócitos (dados não demonstrados).

A Figura 8 mostra que a MT-I causou um aumento significativo da desgranulação dos mastócitos, quando comparado ao controle basal e que a incubação das células com o veículo dos inibidores não alterou este efeito. O pré-tratamento das células com a Wortmanina acarretou uma redução significativa, de aproximadamente $50 \%$, da desgranulação dos mastócitos, induzida pela MT-I, quando comparado ao controle positivo. Em contraste, o tratamento das células com os compostos SB202190, PD98059, H-7, Herbimicina A e Junk Inhibitor II não alterou a desgranulação dos mastócitos estimulada pela MT-I. 


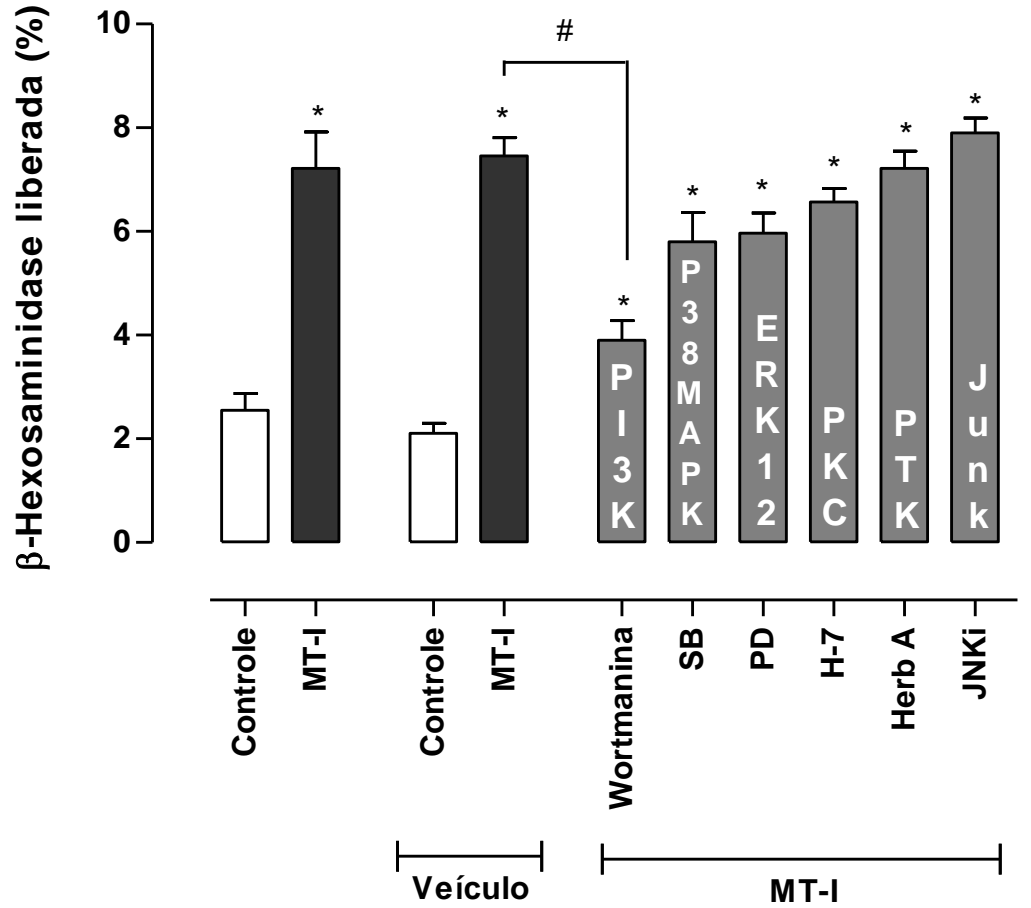

Figura 8. Efeito dos inibidores de proteínas quinase na desgranulação de mastócitos induzida pela MT-I. Os mastócitos (6×10 ${ }^{4}$ células/poço)foram previamente tratados com os inibidores SB202190, PD98059, Wortmanina, H-7, Herbimicina A, Junk Inhibitor II ou com o veículo dos inibidores, seguido pela incubação da MT-I $(0,35 \mu \mathrm{M})$ ou com Tyrode (controle), por 30 minutos. A desgranulação dos mastócitos foi avaliada pela determinação da liberação da $\beta$-hexosaminidase, como descrito em Material e Métodos. Cada barra representa a média \pm EPM de $n=3$ de 3 experimentos independentes. * $\mathrm{p}<0,05$ em relação ao controle basal; ${ }^{*} \mathrm{p}<0,05$ em relação ao grupo MT-I + Veículo (2-way ANOVA seguida por teste de Tukey). 


\subsection{Ativação da PI3K pela MT-I}

Para confirmar que a PI3K foi ativada pela MT-I, foi avaliada a fosforilação da proteína por Western Blotting.

Como pode ser observado na Figura 9-A, a MT-I $(0,35 \mu \mathrm{M})$ causou o aumento da fosforilação da PI3K aos 5 minutos de incubação com os mastócitos. Este efeito foi de intensidade similar quando os mastócitos foram incubados com o ionóforo de cálcio $(1 \mu \mathrm{M})$. A análise densitométrica das bandas, na Figura 9-B, demonstra que o aumento na fosforilação da PI3K causado pela MT-I foi estatisticamente significante, se comparado ao controle. Neste ensaio, o ionóforo de cálcio foi utilizado somente como um controle positivo e, portanto, não foi comparado estatisticamente com os demais grupos.

A

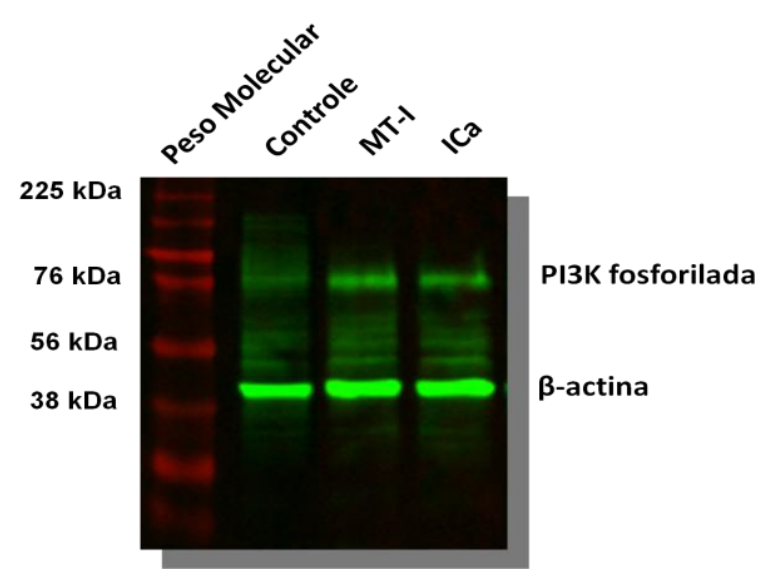

B

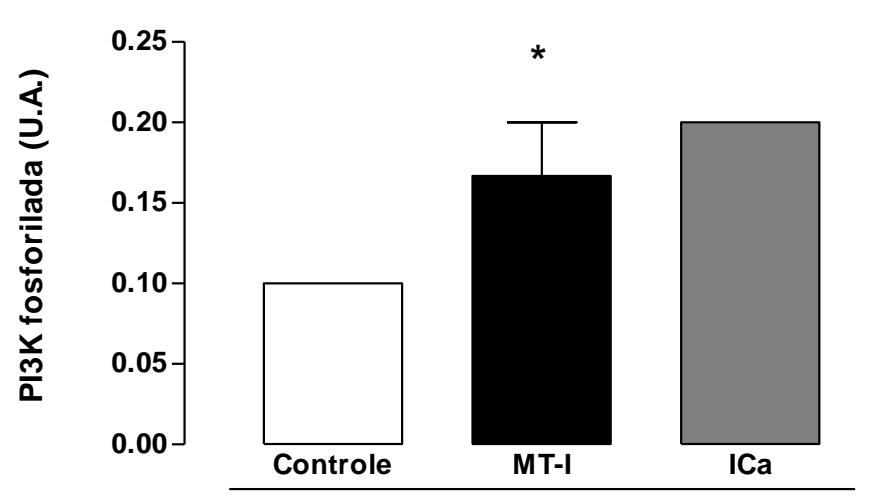

Figura 9. Ativação da PI3K em mastócitos incubados com a MT-I. Os mastócitos ( $3 \times 10^{6}$ células/poço) foram incubados com o ionóforo de cálcio $(1 \mu \mathrm{M})$, com a MT-I $(0,35 \mu \mathrm{M})$ ou com DMEM (controle), por 5 minutos. A fosforilação da PI3K foi avaliada por Western Blotting, como descrito em Material e Método. Cada barra representa a média \pm EPM de $n=3$ de 2 experimentos independentes. ${ }^{*} \mathrm{p}<0,05$ em relação ao controle basal (teste t-Student). 


\subsection{Participação das fosfolipases $A_{2}$ intracelulares e das fosfolipases C e D na desgranulação de mastócitos induzida pela MT-I}

$\mathrm{O}$ envolvimento das fosfolipases $\mathrm{A}_{2}$ citosólica e independente de cálcio $\left(\mathrm{cFLA}_{2} \mathrm{e}\right.$ $\mathrm{iFLA}_{2}$, respectivamente) e das fosfolipases C e D (FLC e FLD, respectivamente) na desgranulação dos mastócitos, induzida pela MT-I, foi avaliado a partir de intervenções farmacológicas com inibidores seletivos de cada uma das enzimas mencionadas.As células foram incubadas com os compostos Bel (inibidor da iFLA 2 ), Pyr-2 (inibidor da cFLA 2 ), U73122 (inibidor da FLC), FIPI (inibidor da FLD) ou seus veículos (controles), antes da adição da MT-I $(0,35 \mu \mathrm{M})$ e a desgranulação avaliada 30 minutos após este estímulo. Cabe ressaltar que, em ensaios preliminares, verificou-se que nas concentrações e tempos estudados, nenhum dos compostos utilizados ou seus veículos causaram alterações significativas da viabilidade celular e nem induziram a desgranulação dos mastócitos (dados não demonstrados).

A Figura 10 mostra que a MT-I causou um aumento significativo da desgranulação dos mastócitos, quando comparado ao controle e que a incubação prévia das células com o veículo dos inibidores não alterou este efeito. Por outro lado, o pré-tratamento dos mastócitos com os compostos Pyr-2, FIPI e U-73122 causou uma diminuição significativa da desgranulação dos mastócitos induzida pela MT-I, se comparado ao controle positivo. Em contraste, a inibição da iFLA 2 , pelo composto BEL não causou alteração estatisticamente significante da desgranulação dos mastócitos estimuladas pela MT-I, em relação ao controle positivo. 


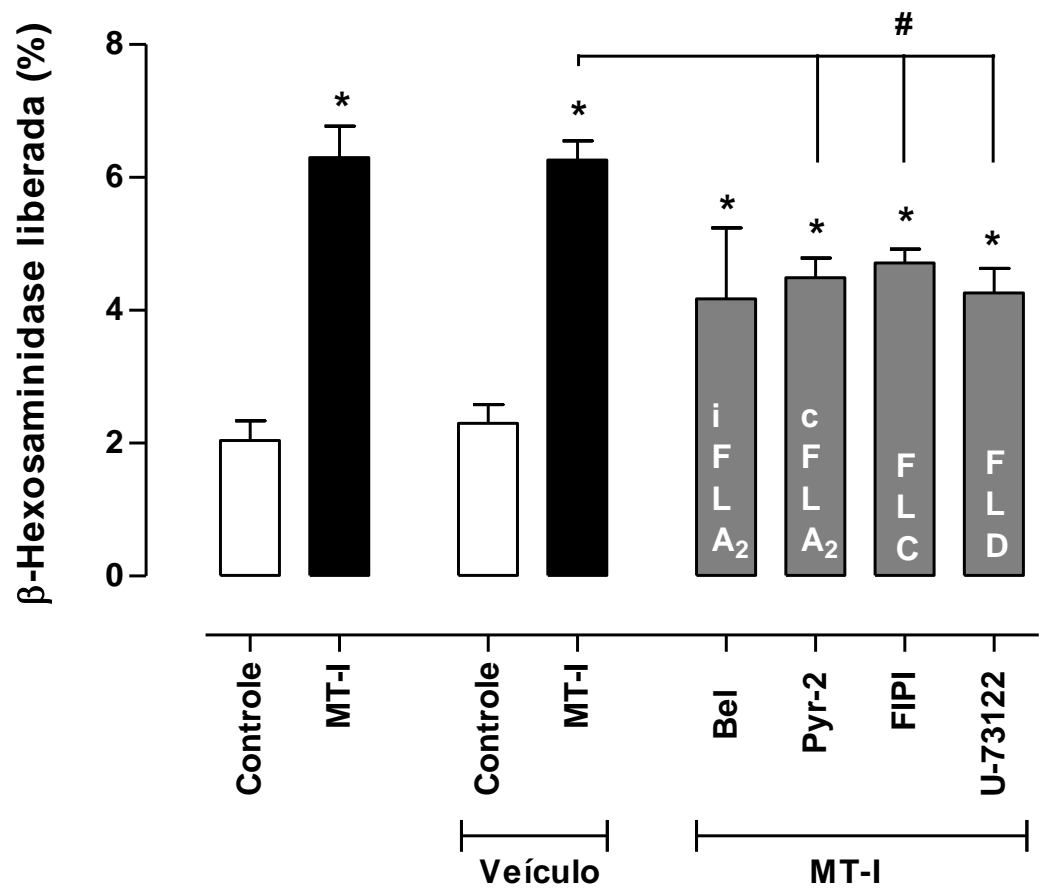

Figura 10. Efeito dos inibidores das fosfolipases $A_{2}$ intracelulares, $C$ e $D$ na desgranulação de mastócitos induzida pela MT-I.Os mastócitos $\left(6 \times 10^{4}\right.$ células/poço)foram previamente tratados com os inibidores Bel, Pyr-2, FIPI, U-73122 ou com o veiculo (< de 1\% de DMSO diluído em Tyrode), seguido pela incubação com a MT-I $(0,35 \mu \mathrm{M})$ ou com Tyrode (controle basal) por 30 minutos. A desgranulação dos mastócitos foi avaliada pela determinação da liberação da $\beta$-hexosaminidase, como descrito em Material e Métodos. Cada barra representa a média \pm EPM de $n=4$ de 3 experimentos independentes. ${ }^{*} \mathrm{p}<0,05$ em relação ao controle; ${ }^{*} \mathrm{p}<0,05$ em relação ao grupo MT-I + veículo (2-way ANOVA seguida por Tukey). 


\subsection{Envolvimento das proteínas G na desgranulação de mastócitos induzida pela MT-I}

O envolvimento das proteínas $G_{\alpha i}$ e $G_{\alpha q}$ na desgranulação dos mastócitos induzida pela MT-I foi avaliado pela utilização de inibidores seletivos para cada isoforma da proteína de interesse (Toxina B de Clostridium difficile e toxina Pertussis ou PTX), como descrito em Material e Métodos. Além das concentrações já descritas na literatura como eficazes, foram testadas concentrações maiores. Nenhum dos inibidores, utilizados isoladamente, nas concentrações e tempos estudados, ou seus veículos, causaram alterações significativas da viabilidade celular e nem induziram a desgranulação dos mastócitos (dados não demonstrados).

A Figura 11 mostra que a MT-I causou um aumento significativo da desgranulação dos mastócitos, quando comparado ao controle basal e que a incubação das células com o veículo dos inibidores não alterou este efeito. O pré-tratamento das células com toxina $\mathrm{B}$ de Clostridium difficile ou com a PTX não alterou a desgranulação dos mastócitos, induzida pela MT-I, quando comparada ao controle positivo (MT-I + veículo).

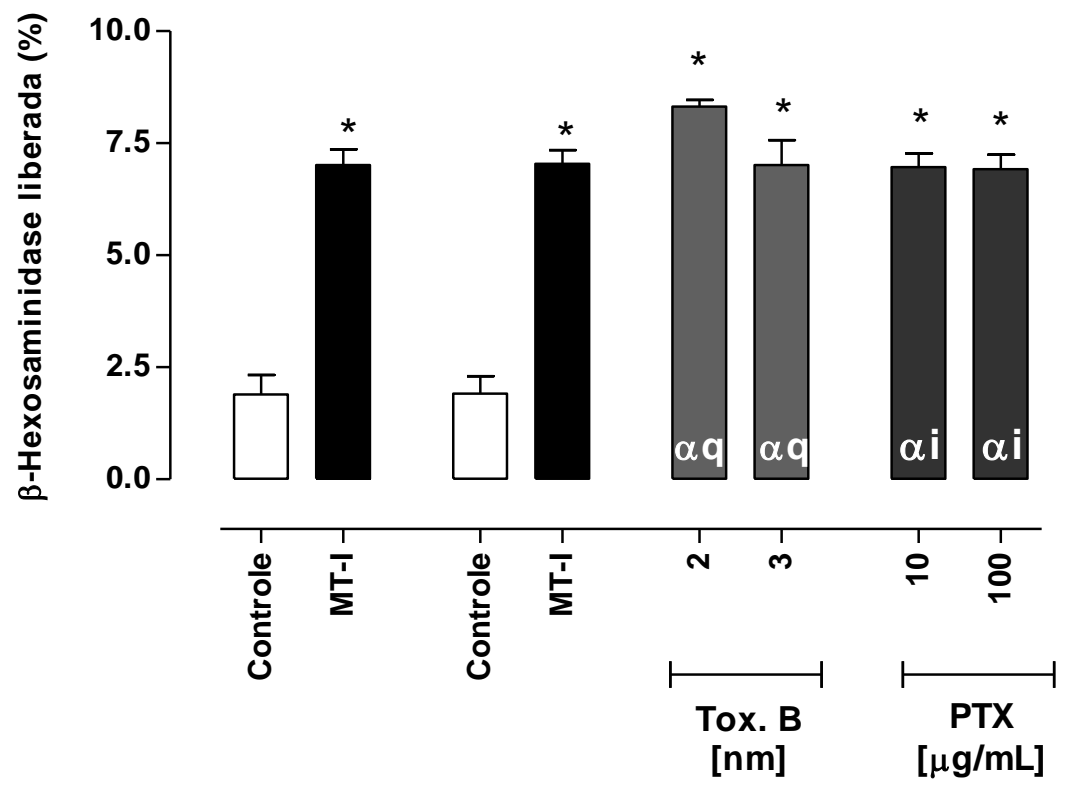

Figura 11. Efeito dos inibidores dasproteínas Gai e Gaq na desgranulação de mastócitos induzida pela

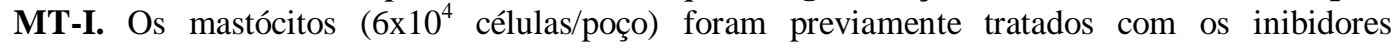
Clostridium difficile toxina B e toxina Pertussis (PTX) ou com o veículo dos inibidores, seguido pela incubação da MT-I $(0,35 \mu \mathrm{M})$ ou com Tyrode (controle), por 30 minutos. A desgranulação dos mastócitos foi avaliada pela determinação da liberação da $\beta$-hexosaminidase, como descrito em Material e Método. Cada barra representa a média \pm EPM de $n=3$ de 3 experimentos independentes. *p<0,05 em relação ao controle basal (2-way ANOVA seguida por teste de Tukey). 


\subsection{Envolvimento do cálcio citoplasmático e extracelular na desgranulação de mastócitos induzida pela MT-I}

O cálcio é um íon relevante em diversos processos fisiológicos e fisiopatológicos dos mastócitos. Para avaliar o envolvimento do cálcio intracelular,proveniente do retículo endoplasmático, e do cálcio extracelular, na desgranulação dos mastócitos induzida pela MTI, foram utilizadas intervenções farmacológicas com inibidores seletivos de cada uma dessas fontes, como descrito em Material e Métodos. Vale ressaltar que, nas concentrações estudadas, nenhum dos compostos utilizados ou seus veículos causaram alterações significativas da viabilidade celular nem induziram desgranulação dos mastócitos (dados não demonstrados).

Como demonstrado na Figura 12, a MT-I causou um aumento significativo da desgranulação dos mastócitos, quando comparado ao controle. Este efeito não foi alterado quando as células foram incubadas com o veículo dos inibidores. O tratamento prévio dos mastócitos com o composto Xestospongina-C, inibidor do $\mathrm{IP}_{3} \mathrm{R}$, causou uma redução significativa, de aproximadamente $40 \%$, da desgranulação induzida pela MT-I, quando comparado com o controle positivo. De modo similar, o pré-tratamento das células com o YM-58483 ou com a nifedipina, inibidores do CRAC e LTCC, respectivamente, causou uma diminuição significativa (de aproximadamente 20\%) da desgranulação dos mastócitos estimulados pela MT-I, em relação ao controle positivo. 


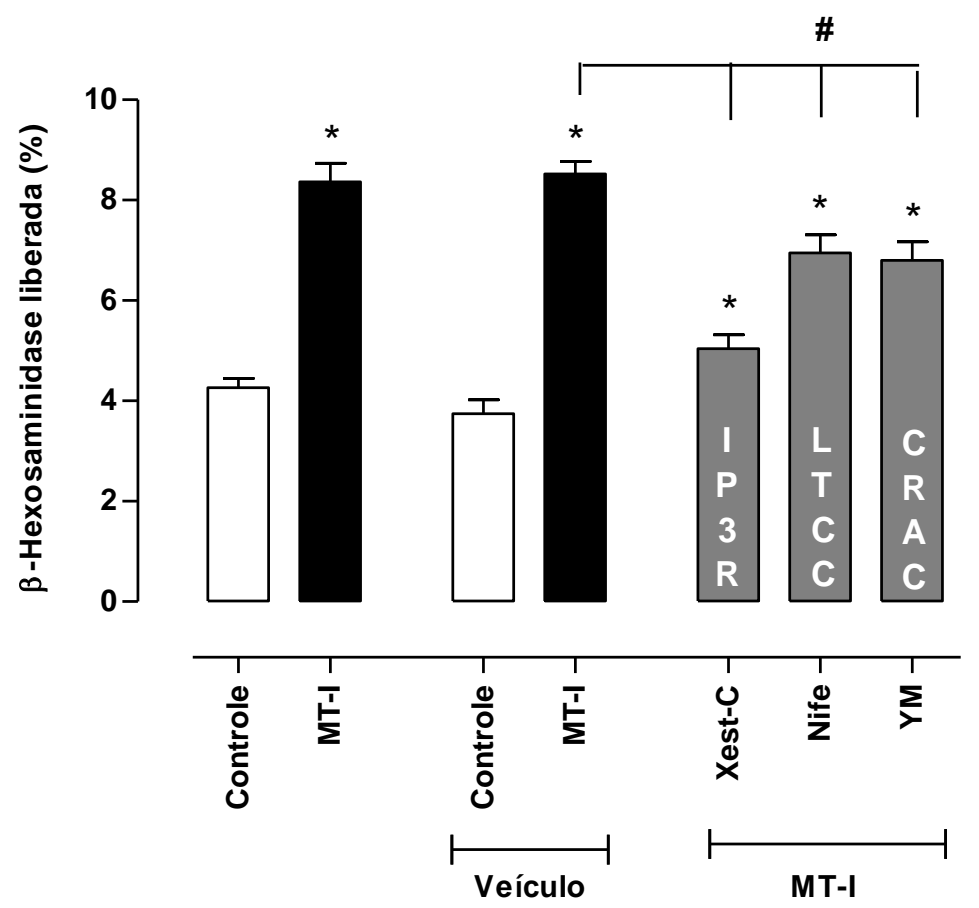

Figura 12. Efeito dos inibidores de cálcio na desgranulação de mastócitos induzida pela MT-I. Os mastócitos $\left(6 \times 10^{4}\right.$ células/poço)foram previamente tratados com os inibidores Xestospongina C, Nifedinamida ou YM-58483 seguido pela incubação da MT-I $(0,35 \mu \mathrm{M})$ ou com Tyrode (controle) por 30 minutos. A desgranulação dos mastócitos foi avaliada pela determinação da liberação da $\beta$ hexosaminidase, como descrito em Material e Métodos. Cada barra representa a média \pm EPM de $\mathrm{n}=3$ de 3 experimentos independentes. ${ }^{*} \mathrm{p}<0,05$ em relação ao controle; ${ }^{\#} \mathrm{p}<0,05$ em relação ao grupo MT-I + veículo (2-way ANOVA seguida por teste de Tukey). 


\subsection{Liberação de $\mathrm{PGE}_{2}$ induzida pela MT-I em mastócitos}

Para este estudo, os mastócitos foram incubados com a MT-I $(0,35 \mu \mathrm{M})$, com o ionóforo de cálcio A-23187 (ICa, $1 \mu \mathrm{M}$ ) ou Tyrode (controle basal), por 1, 3 ou 6 horas e o sobrenadante das células foi utilizado para a determinação da concentração da prostaglandina $\mathrm{E}_{2}$.

Como pode ser observado na Figura 13, a MT-I causou um aumento significativo da liberação da $\mathrm{PGE}_{2}$, somente na $3^{\mathrm{a}}$ hora de incubação, em comparação ao controle basal. O ICa (controle positivo) também causou um aumento significativo da liberação de $\mathrm{PGE}_{2}$, somente na $3^{\text {a }}$ hora de incubação, se comparado ao controle. Este efeito do ICa foi estisticamente diferente em relação ao controle, mas não em relação à MT-I.

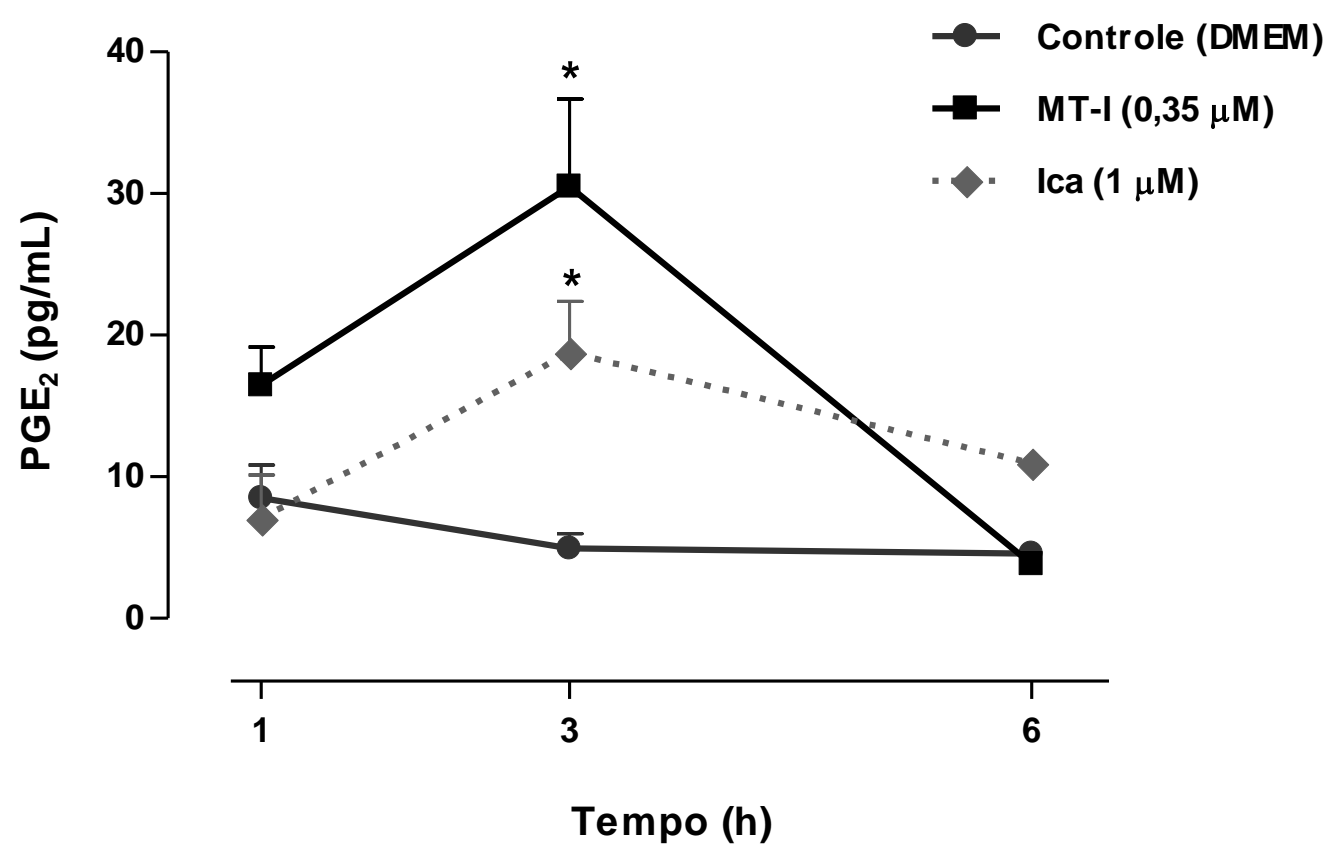

Figura 13. Dosagem de $\mathrm{PGE}_{2}$ após estimulação dos mastócitos com a MT-I. Os mastócitos $\left(6 \times 10^{4}\right.$ células/poço) foram incubados com a MT-I $(0,35 \mu \mathrm{M})$, com o ICa $(1 \mu \mathrm{M})$ ou com o DMEM (controle basal), por diferentes períodos de tempo e o sobrenadante foi utilizado para a dosagem de $\mathrm{PGE}_{2}$ por Ensaio Imunoenzimático (EIA), como descrito no Material e Métodos. Cada barra representa a média \pm EPM de $n=3$ de 3 experimentos independentes (2-way ANOVA seguido por Tukey). 


\subsection{Ativação de genes de citocinas de perfil Th1 e Th2 em mastócitos estimulados pela MT-I}

Considerando a plasticidade dos mastócitos em induzir diferentes respostas, foi avaliada a transcrição de genes relacionados à síntese de citocinas de perfil Th1 e Th2, em mastócitos ativados pela MT-I, em diferentes períodos de tempo. Como pode ser observado na Figura 13, a MT-I causou um aumento estatisticamente significativo dos transcritos para o TNF- $\alpha$ e IL-6 (Figura 14-A e B, respectivamente), na $3^{\text {a }}$ hora de incubação, mas não alterou a expressão basal da IL-1 $\beta$ (Figura 13-C), quando comparados aos respectivos controles. Com relação aos genes de resposta Th2, a Figura 14-C, -D e -E mostra que a MT-I causou um aumento significativo dos transcritos para IL-4, IL-5 e IL-13, respectivamente, na $3^{\text {a }}$ hora de incubação, em relação aos respectivos controles. 


\section{Th1}

A

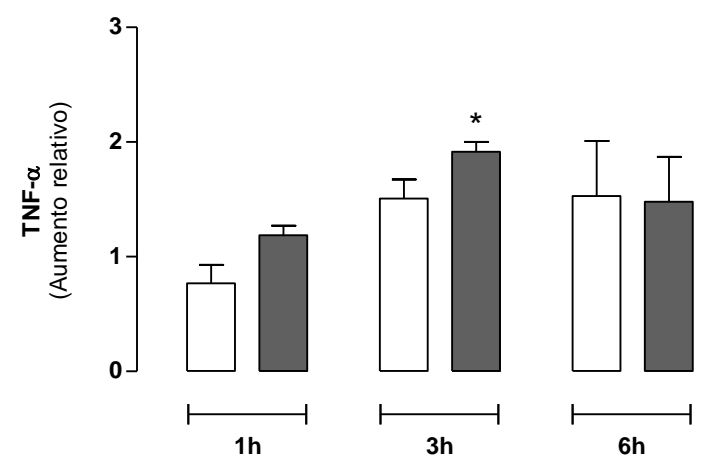

$\mathbf{B}$
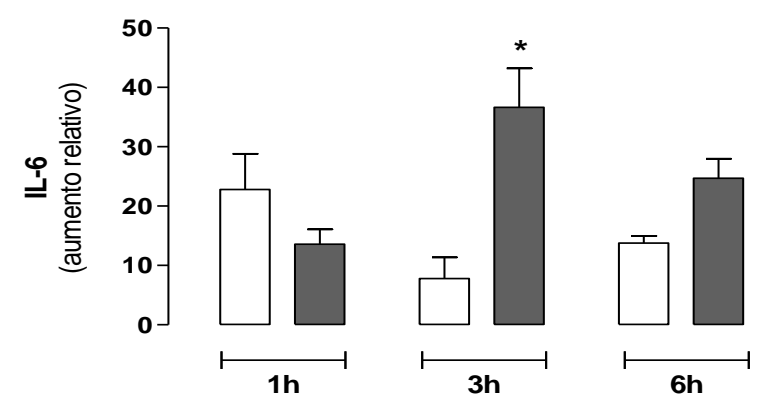

C

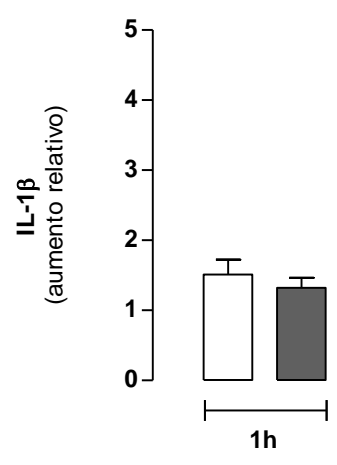

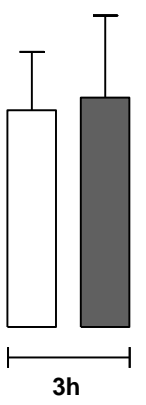

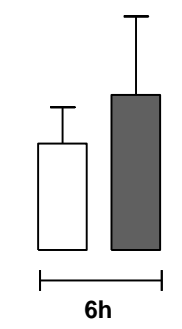

Th2

D

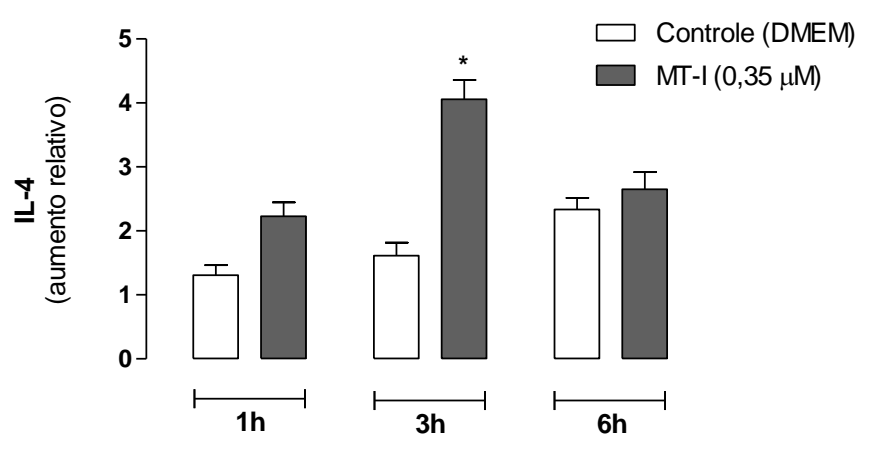

$\mathbf{E}$

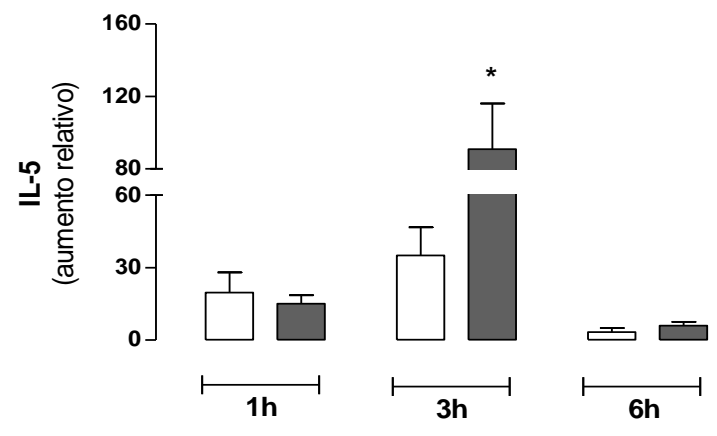

$\mathbf{F}$

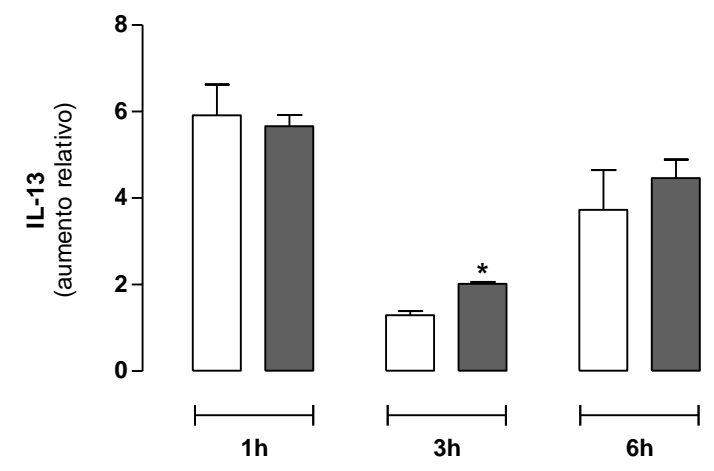

Figura 14. Efeito da MT-I na expressão gênica de mastócitos em cultura. Os mastócitos foram incubados com a MT-I $(0,35 \mu \mathrm{M})$ ou com DMEM (controle) por diferentes de períodos de tempo. O RNA total das células foi purificado e convertido em cDNA por transcriptase reversa. A amplificação das amostras foi realizada em sistema de PCR em tempo real, como descrito em Material e Métodos. Cada barra representa a média \pm EPM de $n=4-5$ de 2 experimentos independentes(2-way ANOVA seguida por Tukey). 


\subsection{Alterações ultraestruturais induzidas pela MT-I em mastócitos}

As alterações morfológicas apresentadas por mastócitos ativados, ou não, pela MT-I, foram analisadas por microscopia eletrônica de transmissão.

Como pode ser observado, os mastócitos do grupo controle (Figuras 15), incubados somente com meio de cultura, apresentaram algumas organelas dispersas pelo citosol, como mitocôndrias $(\mathrm{M})$, complexo golgiense $(\mathrm{G})$, lissossomos $(\mathrm{L})$, regiões de clatrina (indicada pelas setas), corpos multivesiculares (CMV) e vesículas secretórias (VS). Nas células incubadas com a MT-I, por 1 hora (Figuras 16, 17 e 18), pode-se observar um aumento do número de regiões e de vesículas com deposição sugestiva de clatrina (indicado pelas setas), aumento da região e do número de complexos golgienses $(\mathrm{G})$, aparecimento de inclusões lipídicas (LD) e um aumento expressivo do número de vesículas secretórias contendo material heterogêneo (material forte e fracamente eletrondenso). Além disso, foi observado maior proximidade das vesículas secretórias e mesmo o processo de exocitose na presença da MT-I.

Apesar da correta identificação do conteúdo intravesicular, em microscopia eletrônica, exigir a utilização de marcadores específicos, foi realizada a contagem do número de vesículas secretórias (VS) em células controle ou incubadas com a MT-I, por 1 hora. Como pode ser observado na Figura 19, as células do grupo controle (como observado na Figura 15), apresentam uma média de 6 vesículas por célula. Quando as células foram incubadas com a MT-I (Figuras 16-18) houve um aumento, de cerca de 100\%, no número destas vesículas. Este aumento foi estatisticamente diferente daquele observado no grupo controle e demonstra qua a MT-I aumentou o número de grânulos no mastócito. 

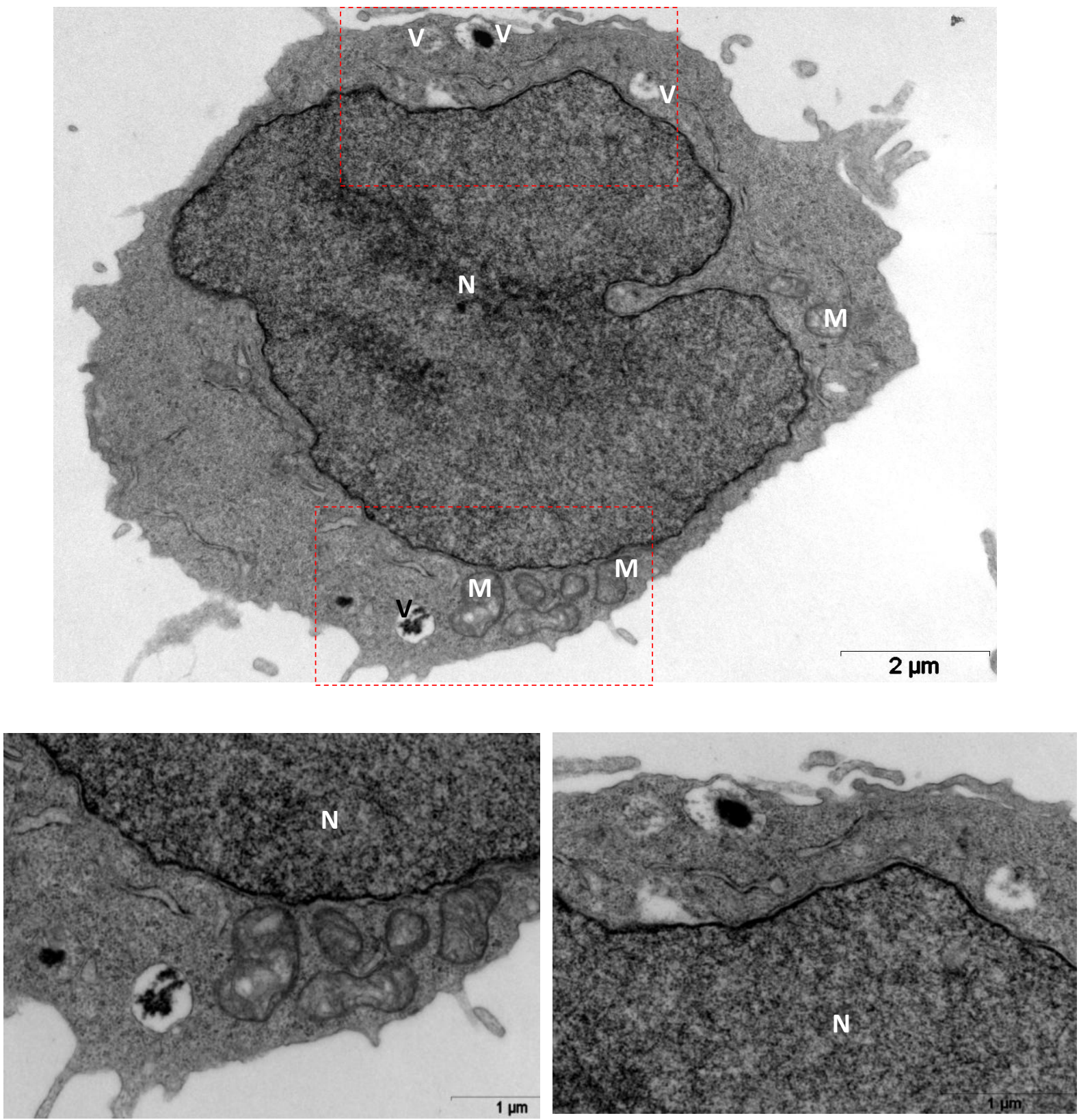

Figura 15. Imagem ultraestrutural de mastócitos controle. Os mastócitosforam incubados com DMEM, por 1 hora e processados para TEM, conforme descrito em Material e Métodos. Legenda: N (núcleo), M (mitocôndria), V (Vesículas). 

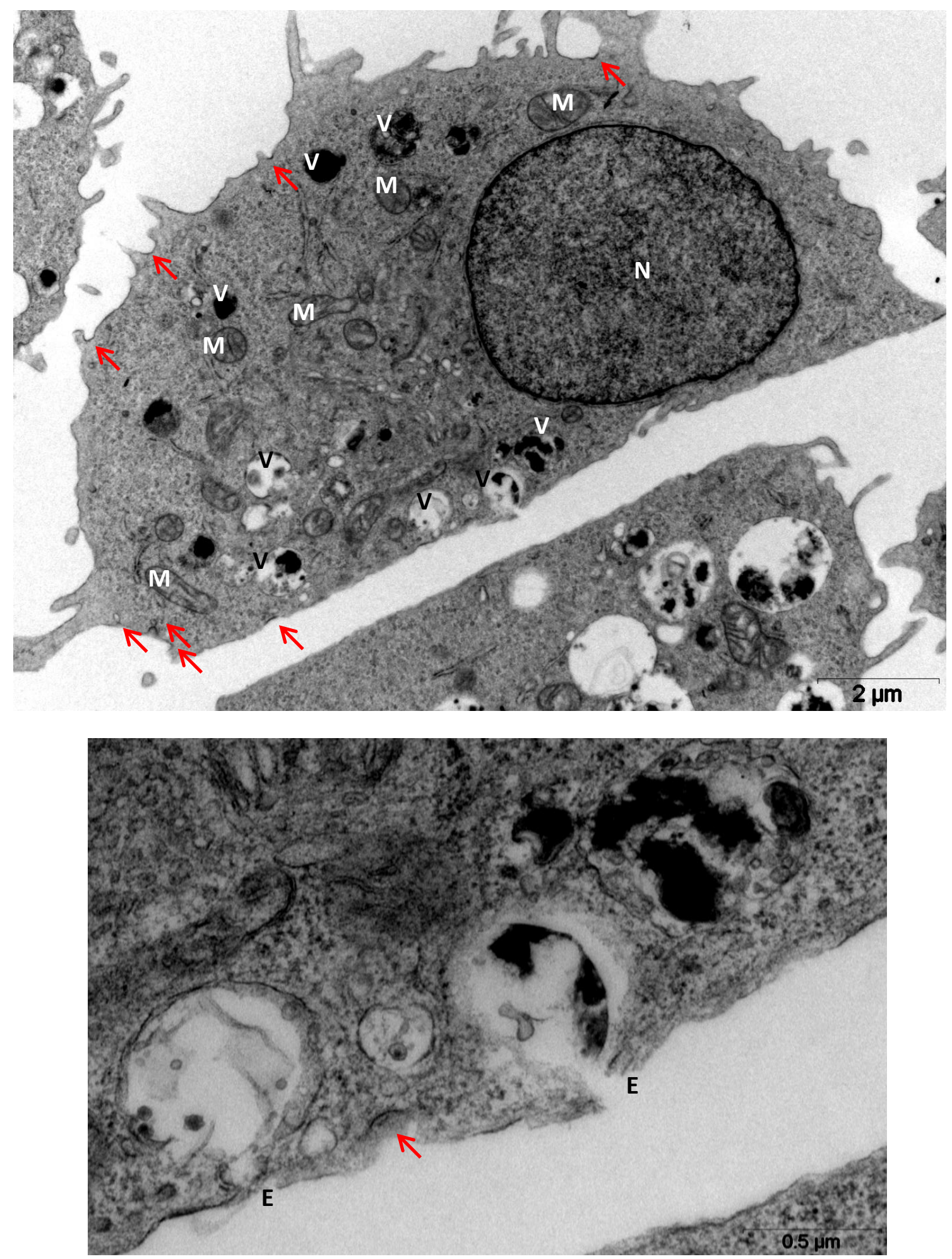

Figura 16. Imagem ultraestrutural de mastócitos ativados pela MT-I. Os mastócitos foram incubados com a MT-I $(0,35 \mu \mathrm{M})$,por 1 hora e processados para TEM, conforme descrito em Material e Métodos. Legenda: N (núcleo), M (mitocôndria), V (Vesículas), Exocitose (E), setas (clatrina). 

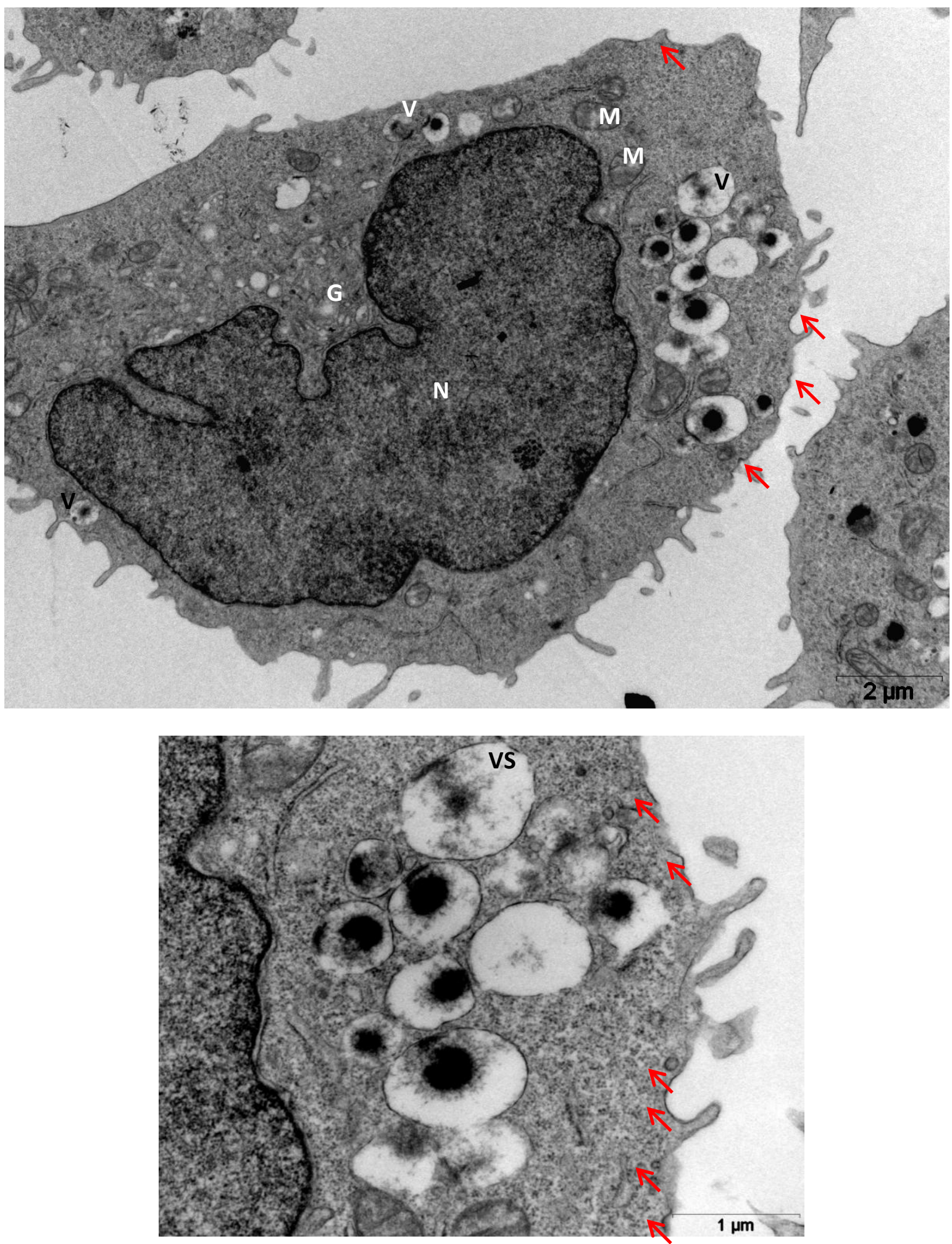

Figura 17. Imagem ultraestrutural de mastócitos ativados pela MT-I. Os mastócitosforam incubados com a MT-I $(0,35 \mu \mathrm{M})$ por 1 hora e processados para TEM, conforme descrito em Material e Métodos. Legenda: N (núcleo), M (mitocôndria), G (Complexo Golgiense), V (Vesículas), setas (clatrina). 

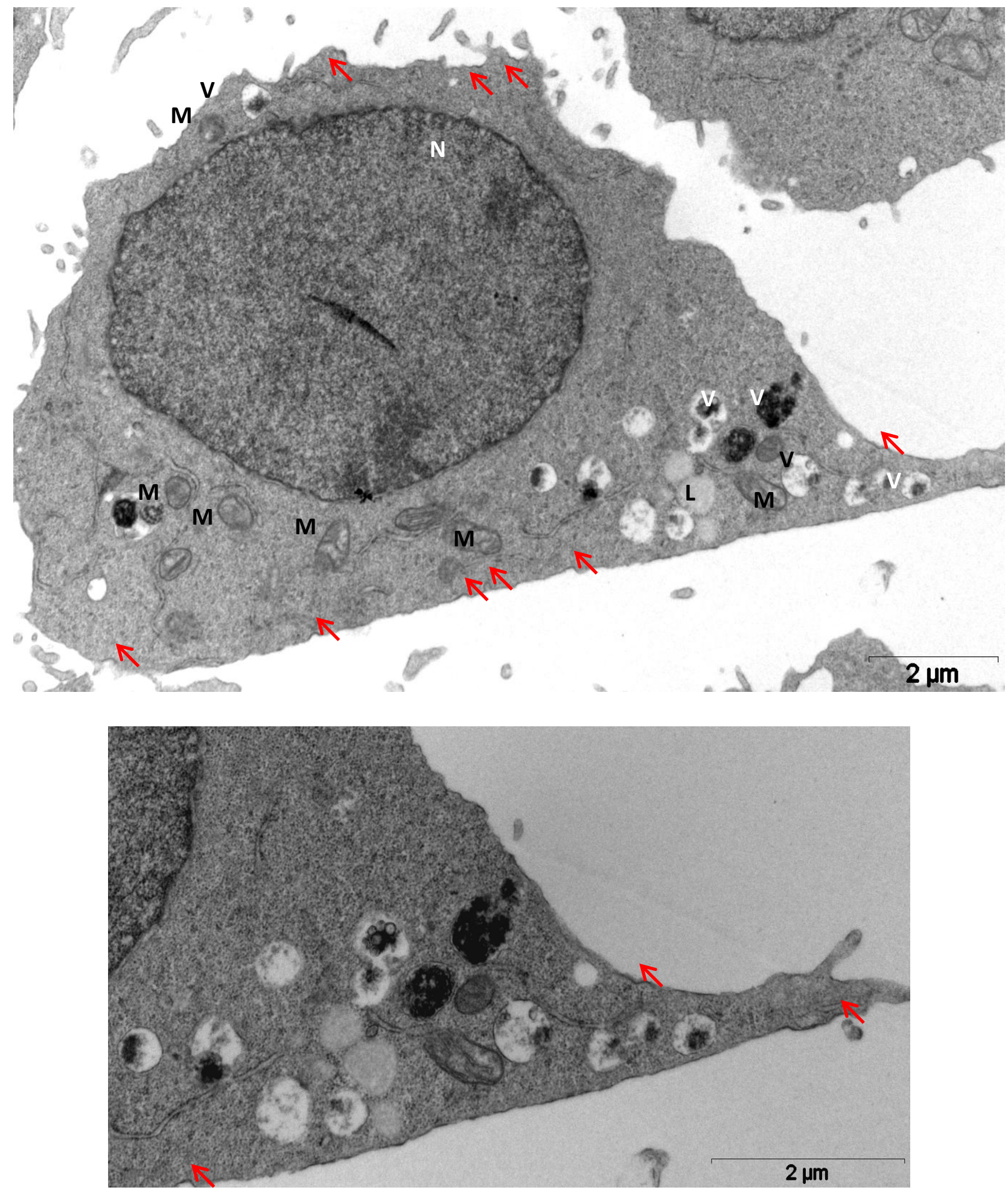

Figura 18. Imagem ultraestrutural de mastócitos ativados pela MT-I. Os mastócitosforam incubados com a MT-I $(0,35 \mu \mathrm{M})$ por 1 hora e processados para TEM, conforme descrito em Material e Métodos. Legenda: N (núcleo), M (mitocôndria), L (corpúsculo lipídico) V (Vesículas), setas (clatrina). 


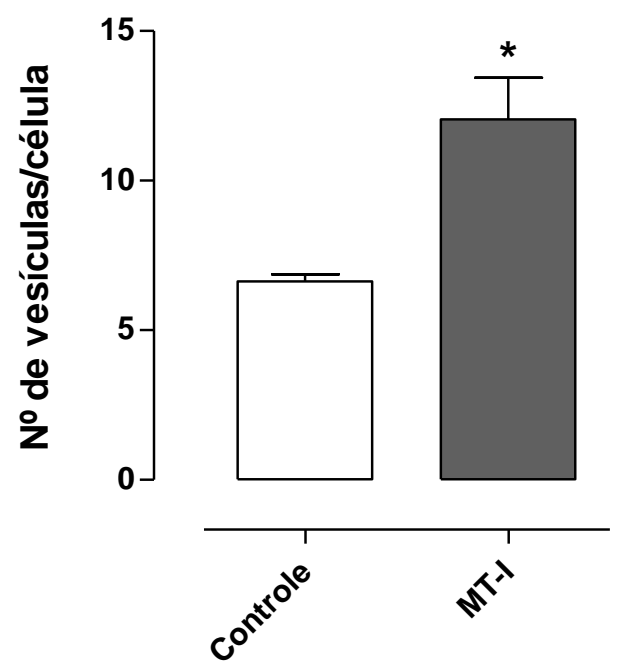

Figura 19. Efeito da MT-I no número de vesículas secretórias de mastócitos. O número de vesículas foi contado a partir dasfotomicrografias eletrônicas de mastócitos incubados com meio de cultura ou com a MT-I $(0,35 \mu \mathrm{M})$, por 1 hora, como descrito em Material e Métodos. Cada barra representa a média \pm EPM de pelo menos 30 células e $n=3$. ${ }^{*}<<0,05$ em relação ao controle (Teste $\left.t-S t u d e n t\right)$. 


\subsection{Efeito do veneno de Bothrops asper (VBa) na desgranulação dos mastócitos}

Para verificar se a ação das fosfolipases $\mathrm{A}_{2}$ (MT-I e MT-II) teria repercussão no efeito final do veneno da $B$. asper (VBa) sobre os mastócitos, já que estas sPLA ${ }_{2} \mathrm{~S}$ estão em concentrações elevadas neste veneno, concentrações não citotóxicas do VBa (dados não demonstrados) foram incubadas com os mastócitos. Como mostra a Figura 20, ambas as concentrações testadas do $\operatorname{VBa}(0,5$ e $1 \mu \mathrm{g} / \mathrm{mL})$ causaram a desgranulação dos mastócitos, de modo significativo, em relação ao controle basal, mas não difereriram do efeito da MT-I.

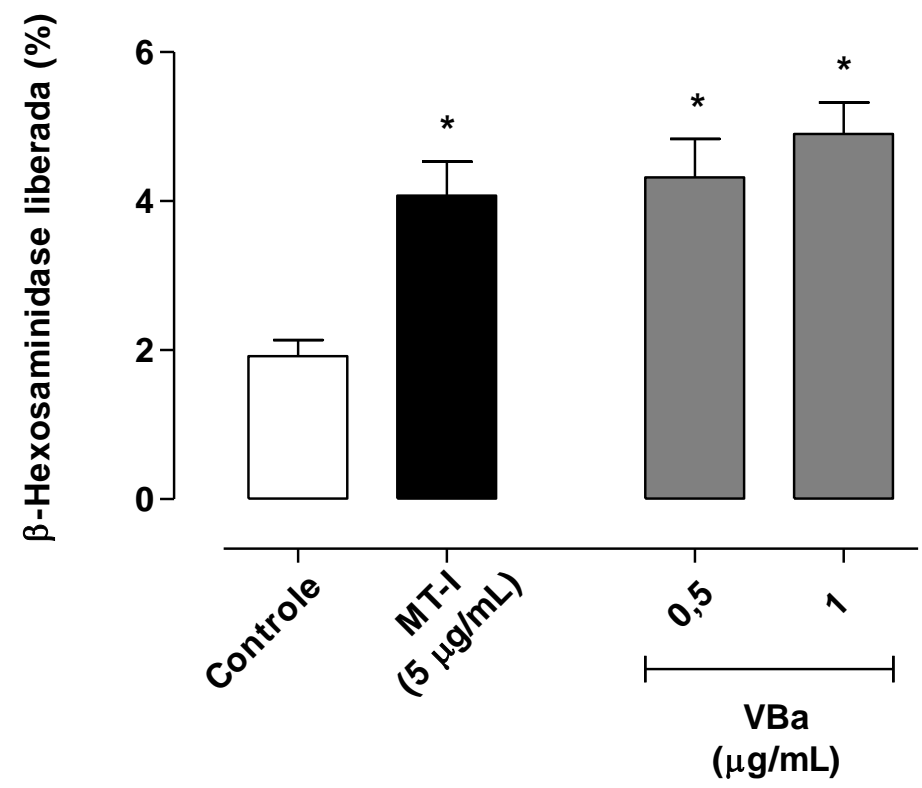

Figura 20. Efeito do veneno de Bothrops asper (VBa)na desgranulação de mastócitos em cultura. Os mastócitos $\left(6 \times 10^{4}\right.$ células/poço) foram incubados com a MT-I $(5 \mu \mathrm{g} / \mathrm{mL}$, correspondente a 0,35 $\mu \mathrm{M})$, com o VBa ou com Tyrode (controle negativo) por 30 minutos em estufa de $\mathrm{CO}_{2}$ a $5 \%$ e a 37 ${ }^{\circ} \mathrm{C}$. A desgranulação dos mastócitos foi avaliada pela determinação da liberação da $\beta$ hexosaminidase, como descrito em Material e Método. Cada barra representa a média \pm EPM de $\mathrm{n}=3$ de 3 experimentos independentes *p<0,05 em relação ao controle (1-way ANOVA seguida por teste de Tukey). 


\section{DISCUSSÃO}

Os mastócitos são células relevantes em diversos processos fisiológicos e patológicos e a sua desgranulação e liberação de mediadores estocados e recém-sintetizados constitui um dos principais eventos desencadeados após a ativação dessas células, por diferentes estímulos. As fosfolipases $\mathrm{A}_{2}$ secretadas $\left(\mathrm{sFLA}_{2} \mathrm{~s}\right)$, encontradas em concentrações elevadas em venenos de serpentes da família Viperidae, representam estímulos que causam a desgranulação dos mastócitos. Contudo, os mecanismos envolvidos neste efeito não haviam sido investigados.

Os resultados do presente estudo demonstraram que MT-I, em concentrações não citotóxicas, ativou mastócitos em cultura, de modo direto, e causou a desgranulação destas células. Este efeito não apresentou proporcionalidade entre as concentrações testadas, uma vez que todas concentrações apresentaram magnitude similar entre si. Além disso, a magnitude deste efeito da MT-I não diferiu daquele observado com o ionóforo de cálcio (ICa), utilizado como controle positivo. Além disso, o fato da MT-I ter induzido o mesmo efeito, em concentração três vezes menor que a do $\mathrm{ICa}$, demonstra a potencia desta fosfolipase $\mathrm{A}_{2}$ para a indução da desgranulação dos mastócitos. Em contraposição aos dados deste estudo, foi descrito que $\mathrm{sFLA}_{2} \mathrm{~s}$, isoladas do veneno das serpentes B.atrox, B. jararacussu e B. pirajai, causaram a desgranulação de mastócitos mesentéricos de ratos, de modo dependente da concentração (KANASHIRO et al., 2002; LANDUCCI et al. 1998, 2000). Esta diferença pode estar relacionada à diferenças estruturais entre enzimas de cada uma das espéciesestudadas e/ou aos modelos experimentais utilizados.

Com relação ao perfil temporal, foi observado que a MT-I induziu uma desgranulação de magnitude crescente ao longo do tempo, com início aos 15 minutos. Estes resultados evidenciam que a MT-I é capaz de desgranular e liberar os mediadores estocados nos mastócitos, de modo rápido, sendo este efeito potencializado ao longo do tempo.

As evidências da literatura indicam que as $\mathrm{sFLA}_{2} \mathrm{~S}$ de venenos podem desencadear seus efeitos de modo independente de sua atividade enzimática (CINTRAFRANCISCHINELLI et al., 2010; LOMONTE; GUTIÉRREZ, 2011;ZULIANI et al., 2005). Deste modo, avaliamos o efeito da MT-I, com a atividade enzimática inativada pela alquilação do seu sítio catalítico, pelo composto químico brometo de parabromofenacila (BPB). Os resultados obtidos mostraram que esta inibição reduziu a desgranulação dos mastócitos em 50\%, quando comparado ao efeito da MT-I cataliticamente ativa (forma nativa). Estes resultados indicam que a atividade enzimática da MT-I é importante para a desgranulação dos mastócitos, mas não essencial para desencadear este efeito e que outras 
regiões da molécula, distintas do sítio catalítico, também contribuem para este efeito. Além disso, os resultados sugerem que outras regiões da molécula, distintas do sítio catalítico, também contribuem para este efeito. O BPB é um composto químico alquilante que liga-se covalentemente na histina 48, que compõe o sítio catalítico da $\mathrm{SFLA}_{2}$, inibindo sua atividade enzimática (MAGRO et al., 2005; MARCUSSI et al., 2007; SOARES; GIGLIO, 2003). Apesar desta inibição ser amplamente utilizada na literatura, seu uso ainda é controverso. Alguns autores sugerem que esta inibição pode causar alterações conformacionais nas sFLA que poderia ocultar sítios não catalíticos responsáveis pelos efeitos biológicos das mesmas (MAGRO et al., 2005; SOARES; GIGLIO, 2003; ZHAO et al., 1998). Com base nestas informações e para corroborar os resultados obtidos neste estudo, avaliou-se o efeito da MTII, uma sFLA 2 homóloga à MT-I, destituída de atividade catalítica por apresentar o aminoácido lisina, na posição 49, em substituição ao aspartato, presente nas sFLA $_{2}$ cataliticamente ativas. Os resultados mostraram que a MT-II também induziu a desgranulação dos mastócitos, porém, somente com o dobro da concentração da MT-I. Estes resultados reforçam os dados anteriores, que indicam que a atividade catalítica da $\mathrm{sFLA}_{2}$ não é essencial para a desgranulação dos mastócitos. A capacidade da MT-II induzir efeitos biológicos já foi demonstrado em modelos experimentais "in vivo" e "in vitro", em leucócitos, como os macrófagos e neutrófilos (MOREIRA et al., 2013; ZULIANI et al., 2005). Em adição, foi demonstrado que um segmento da região C-terminal, que compreende os aminoácidos 115-129, que não faz parte do sítio catalítico, é determinante para as diversas ações biológicas da MT-II, dentre elas a mionecrose e a formação de corpúsculos lipídicos em macrófagos (CALDERÓN; LOMONTE, 1998; CINTRA-FRANCISCHINELLI et al., 2010; GIANOTTI et al., 2013;LOMONTE et al., 1994, 1999, 2010; NÚÑEZ et al., 2001; RANGEL et al., 2011). No presente estudo, não foram determinados quais domínios estruturais da MT-I são responsáveis pelo seu efeito em mastócitos, já que a sua sequência estrutural completa desta proteína ainda não foi determinada.Contudo, considerando as informações acima, é possível sugerir que a região C-terminal da MT-I também esteja envolvida na indução da desgranulação dos mastócitos, embora a participação de outros sítios da molécula não possa ser descartado.

Como mencionado anteriormente, parte dos mecanismos de ação das $\mathrm{sLA}_{2} \mathrm{~s}$ deve-se à sua ligação aos receptores do tipo $\mathrm{M}$, os quais foram identificados em células musculares e em leucócitos, como neutrófilos, monócitos, macrófagos alveolares, mas não em mastócitos, até o momento (LAMBEAU et al., 1990, 1995, 1999; LAMBEAU; GELB, 2008; MURAKAMI et al., 2010; RIZZO et al., 2000; SILLIMAN et al., 2002). Além disso, os 
receptores do tipo $M$, quando ativados, são internalizados e degradados por enzimas lisossomais (HANASAKI; ARITA, 1992; SRIBAR; KRIZAJ, 2011; ZVARITCHet al., 1996). Como no presente estudo foi observado que a MT-I aumenta o número de vesículas endocíticas dependentes de clatrina, nos mastócitos (dados discutidos adiante), é possível supor que este efeito da MT-I decorra da ativação de receptores, como os do tipo M. Adicionamente, foi demonstrado que algumas $\mathrm{sFLA}_{2} \mathrm{~S}$ também podem ligar-se com alta afinidade a outros receptores, como o "receptor 2 do fator de crescimento vascular endotelial" (VEGFR2)(FUJISAWA et al., 2008; YAMAZAKI et al., 2005). Curiosamente, neste mesmo estudo, foi demonstrado que a região de ligação da fosfolipase $A_{2}$, ao receptor VEGFR2, foi a do C-terminal, a mesma descrita como biologicamente ativa em fosfolipases $\mathrm{A}_{2}$ destituídas de atividade enzimática. Além disso, algumas $\mathrm{sFLA}_{2}$ humanas e de serpentes foram capazes de ligar-se a integrinas de membrana e induzir diferentes respostas biológicas, como, por exemplo, a inibição da migração de células tumorais (BAZAA et al., 2009; SAEGUSA; AKAKURA, 2008). Apesar dos resultados do presente estudo não terem avaliado quais seriam os alvos celulares de ligação da MT-I, a literatura relata que diferentes linhagens de mastócitos expressam tanto os receptores do VEGFR, quanto integrinas (DETORAKI et al., 2009; HADLEY; HIGGINS, 2014; VALES et al., 2007). Assim, é plausível supor que a os efeitos da MT-I, nos mastócitos, decorram, ao menos em parte, de sua ligação a esses receptores. Contudo, são necessários estudos adicionais para confirmar esta hipótese.

A seguir, por meio de intervenções farmacológicas específicas, foi investigada a participação de algumas proteínas e vias de sinalização na desgranulação de mastócitos, induzida pela MT-I. Dentre as proteínas quinases avaliadas, observou-se que a PI3K participa, de modo expressivo, da via de sinalização do processo de desgranulação dos mastócitos, induzido pela MT-I, enquanto as proteínas PKC, p38 ${ }^{\mathrm{MAPK}}$, ERK1/2, PTK e a Junk não contribuem para este evento, no período de tempo avaliado. Na literatura, a ativação e desgranulação de mastócitos, induzida por estímulos, como a ligação antígeno/IgE/FCعRI, o ionóforo de cálcio e citocinas, envolve a fosforilação de proteínas tirosina quinases específicas, como as proteínas quinases ativadas por mitógenos (MAPKs), as quinases reguladas por sinais extracelulares (ERKs), a proteína quinase $\mathrm{C}(\mathrm{PKC})$, a proteína tirosino quinase (PTK) e a Junk (AUNG et al., 2011;GILFILLAN et al., 2009; GILFILLAN; TKACZYK, 2006; HEWSON et al., 2011;LAW et al., 2011; ROWAN et al., 2012). Em mastócitos, a fosfatidilinositol-3-quinase (PI3K) representa uma das primeiras proteínas de sinalização a serem recrutadas e pode ativar diversas vias de sinalização nestas células. Esta proteína é fundamental em diversos processos fisiológicos e patológicos, tais como a 
sobrevida, o recrutamento e a adesão celulares e a síntese de citocinas (ALI et al., 2004; DESAI; THURMOND, 2011; KIM et al., 2008; LAFFARGUE et al., 2002; ROWAN et al., 2012). De acordo com a literatura, a ativação da PI3K pode resultar na desgranulação dos mastócitos via ativação subsequente da FLC e da PKC, as quais contribuem para a desgranulação e a produção de citocinas, sob diferentes estímulos (BARKER et al., 1998; CISSEL et al., 1998; METCALFE et al., 2009). Além disso, a ativação dos receptores tipo M, expressos em leucócitos, ativam a via da PI3K (PARK et al., 2003). Deste modo, é possível supor que os mastócitos da linhagem RBL também expressem este receptor e que sua ativação seja um dos mecanismos de ação da MT-I para induzir a desgranulação dos mastócitos. O resultado do presente estudo está de acordo com a literatura, que evidencia um importante papel da PI3K na desgranulação dos mastócitos. Por outro lado, quanto às demais proteínas quinases avaliadas, não pode ser descartada a possibilidade de que as mesmas tenham sido ativadas pela MT-I, mas que participem de outros eventos celulares, não relacionados à desgranulação dos mastócitos. Dentre estes processos, potencialmente ativados pelas proteínas quinases, pode-se citar a síntese de citocinas, que é um evento que ocorre mais tardiamente, em relação à desgranulação. Esta última hipótese está embasada por determinados estudos que demonstraram que as proteínas da família das MAPKs contribuem para a síntese de citocinas, mas não para a desgranulação dos mastócitos da linhagem RBL2H3, estimulados pela via da IgE/antígeno (KUEHN et al., 2011; METCALFE et al., 2009). Também não pode ser descartada a possibilidade de que estas quinases contribuam para o processo de desgranulação, em períodos mais tardios, em que verificamos um aumento expressivo da desgranulação dos mastócitos estimulados pela MT-I (3 e 6 horas). Esta hipótese não pode ser confirmada, na presente condição experimental, em função da elevada citotoxicidade dos inibidores, disponíveis para este estudo, observada em períodos de incubação superiores a 1 hora, com os mastócitos RBL (dados não demonstrados). Cabe ressaltar que esta é a primeira demonstração do efeito de uma $\mathrm{SFLA}_{2}$, de veneno ofídico, na transdução de sinais, em mastócitos.

$\mathrm{AsFLA}_{2} \mathrm{~s}$ citosólicas e indepedente de cálcio (cFLA e $_{2} \mathrm{iFLA}_{2}$, respectivamente) também participam, de modo importante, de diversos eventos em mastócitos. Os resultados do presente estudo demonstraram que a cFLA 2 , mas não a iPLA 2 , contribui para a desgranulação dos mastócitos estimulados pela MT-I. Estes resultados demonstraram, ainda, uma interação entre a MT-I e a cPLA 2 e corroboram dados da literatura, que demonstraram que as $\mathrm{sFLA}_{2} \mathrm{~S}$ interagem, de modo sinérgico, com as $\mathrm{FLA}_{2} \mathrm{~S}$ intracelulares e induzem a produção de eicosanoides, em diferentes células inflamatórias (BALSINDE et al., 1995, 1999; KIM et al., 
2002; MURAKAMI et al., 1998). De modo geral,a cFLA 2 está envolvida na produção de citocinas e eicosanoides, enquanto a $\mathrm{iFLA}_{2}$ está relacionada ao remodelamento de membranas, em diferentes tipos celulares (FUJISHIMA et al., 1999; MURAKAMI et al., 2011; NAKATANI et al., 2000). Os resultados obtidos no presente estudo estão de acordo com os dados da literatura, que demonstraram o envolvimento da cFLA 2 para a desgranulação de mastócitos, incluindo as células RBL-2H3, sob a ação de diferentes estímulos (KIKAWADA et al., 2007; KWON et al., 2012; UENO et al., 2008). No mesmo sentido, testes pré-clínicos demonstraram que a inibição da $\mathrm{cFLA}_{2}$ reduziu a síntese de eicosanoides, por mastócitos pulmonares humanos, estimulados pela ligação antígeno/IgE e minimizou os sintomas da asma (HEWSON et al., 2011). Neste contexto, pode-se sugerir que a cFLA 2 também esteja envolvida na síntese de $\mathrm{PGE}_{2}$, induzida pela MT-I, nos mastócitos RBL-2H3. Até onde pode ser verificado, estes resultados representam a primeira evidência da interação entre uma $\mathrm{sFLA}_{2}$ de serpente e uma $\mathrm{cFLA}_{2}$ de mamífero, resultando na desgranulação de mastócitos.

Como descrito anteriormente, a PI3K é uma proteína chave para ativar uma série de outras proteínas subsequentes, incluindo as FLC e FLD. No presente estudo, verificou-se que a inibição da FLC, pelo composto U-73122, reduziu a capacidade da MT-I promover a desgranulação dos mastócitos, indicando que esta a FLC é importante para o mecanismo de ação da MT-I,para o desencadeamento da desgranulação destas células. Quanto ao mecanismo de ação da FLC, foi demonstrado que, em mastócitos ativados pela via antígeno/IgE, a FLC cliva o 4,5-bifosfato de fosfoinositol, da membrana celular, gerando o trifosfato de inositol $\left(\mathrm{IP}_{3}\right)$ e o diacilglicerol (DAG). $\mathrm{O} \mathrm{IP}_{3}$ liga-se a seu receptor $\left(\mathrm{IP}_{3} \mathrm{R}\right)$, presente no retículo endoplasmático, liberando o cálcio estocado nesta organela, o que culmina na desgranulação dos mastócitos (KAGEYAMA-YAHARA et al., 2011; KUEHN et al., 2007, 2011). Já o DAG, juntamente com o cálcio, liga-se a domínios específicos, presentes na proteína quinase C (PKC), causando sua ativação, que culmina em alterações morfológicas dos mastócitos. A transdução de sinal, mediada pela FLC, na vigência de ação da MT-I, não foi esclarecida. Contudo, pode-se sugerir que a geração de $\mathrm{IP}_{3}$ constituta uma via importante neste processo, já que a PKC não participa do efeito da MT-I.

A FLD é uma outra proteína sinalizadora relevante para a desgranulação dos mastócitos e pode ser ativada em mastócitos da linhagem RBL-2H3, por uma variedade de estímulos, como o ionóforo de cálcio, a tapsigargina, o PMA (forbol éster) e pela via antígeno/IgE/FceRI (CISSEL et al., 1998;HITOMI et al., 2004; LIN; GILFILLAN, 1992; SIRAGANIAN, 2003;WAY et al., 2000; WILSON et al., 1991). Após a sua ativação, a FLD 
cataliza a hidrólise de fosfatidilcolina, gerando o ácido fosfatídico e acolina, a qual origina o diacilglicerol, que ativa a proteína quinase C (PKC), acarretando a liberação de cálcio, polimerização do citoesqueleto, fusão dos grânulos citoplasmáticos e desgranulação (CISSEL et al., 1998; COCKCROFT et al., 2002; GILFILLAN; RIVERA, 2009; JENKINS; FROHMAN, 2005; LIN et al., 1991;MELENDEZ; KHAW, 2002;SIRAGANIAN, 2003; NISHIZUKA, 1995; RIVERA; GILFILLAN, 2006).Ainda, a ativação da FLD induz a formação de microdomínios lipídicos e a ativação de microfilamentos de actina, que acarretam alterações morfológicas em mastócitos ativados e podem contribuir para a desgranulação destas células (FARQUHAR et al., 2002; LISBOA et al., 2009; YANASE et al., 2010). O resultados do presente estudo, demonstraram que a FLD está envolvida na desgranulação dos mastócitos, promovida pela MT-I. Estes dados corroboram, portanto, a literatura mencionada acima e estão de acordo com os estudos que demonstraram a relevância da FLD para a desgranulação de células RBL-2H3, induzida pelo mastoparan,um conhecido peptídio natural, desgranulador de mastócitos, extraído do veneno da vespa Vespula lewisii, e do composto 48/80, um polímero sintético amplamente utilizado como desgranulador de mastócitos (CHAHDI et al., 2000; MOUSLI et al., 1990; PALOMAKI; LAITINEN, 2006; SENYSHYN et al., 1998). Em síntese, o conjunto de dados, discutidos acima evidenciaram a relevância das FLC e FLD como segundos mensageiros da ação da MT-I, em mastócitos, que resulta na desgranulação. Considerando que a PI3K também participa deste evento induzido pela MT-I e que esta proteína sinalizadora é capaz de ativar essas duas enzimas, é plauzível supor que, na presente condição experimental, a ativação das mesmas tenha ocorrido via PI3K. Neste sentido, a literatura demonstra que a ativação da FLC e da FLD, via PI3K, constitui uma via de sinalização relevante, para desgranulação dos mastócitos RBL-2H3, induzida pela interação antígeno/IgE (BARKER et al., 1998; CISSEL et al., 1998; METCALFE et al., 2009).

Um dos mecanismos descritos na literatura para a ativação das fosfolipases C, D e da PI3K, em mastócitos, é dado pela ativação prévia das proteínas G (KEHRL, 2004; MAIER et al., 1999; WEINSTEIN; SCARLATA, 2011;ZHANG; DU, 2009). Porém, no presente estudo, foi verificado que as isoformas $G_{\alpha q}$ e $G_{\alpha i}$, reconhecidas como isoformas relevantes para a desgranulação dos mastócitos, não estão envolvidas neste efeito induzido pela MT-I. Diferentemente do observado no presente estudo, foi demonstrado que o composto 48/80 e o mastoparan podem ativar, diretamente, a proteína $G_{\alpha i}$, presente na face interna da membrana dos mastócitos (FERRY et al., 2001, 2002). Ainda, nestes artigos, foi descrito que a 
subunidade $\beta \gamma$ da proteína $G_{\alpha i}$ é a responsável pela ativação da FLC e FLD, levando à desgranulação dessas células. Estas informações reforçam a sugestão apresentada acima, de que a ativação das FLC e D, pela MT-I, ocorre via ativação da PI3K.

$\mathrm{O}$ cálcio ${ }^{2+}\left(\mathrm{Ca}^{2+}\right)$ é um íon de extrema importância para diversos processos celulares e, nos mastócitos, este íon está implicado na desgranulação e liberação de mediadores inflamatórios (MA; BEAVEN, 2011). Os resultados obtidos no presente estudo demonstraram que tanto o cálcio intracelular, proveniente do retículo endoplasmático, quanto aquele proveniente do meio extracelular, via ativação dos canais CRAC e LTCC, são relevantes para a desgranulação dos mastócitos ativados pela MT-I. De acordo com literatura, as principais fontes de cálcio, envolvidas na ativação de mastócitos, são o cálcio liberado pelo retículo endoplasmático (que representa o cálcio entracelular) e a entrada de cálcio extracelular, pela ativação dos CRAC ("Ca ${ }^{2+}$ entry through store-operated $\mathrm{Ca}^{2+}$ channels") (DI CAPITE et al., 2011; MA; BEAVEN, 2011). A liberação do cálcio do retículo endoplasmático representa um mecanismo inicial, relevante para a ativação e desgranulação dos mastócitos (COHEN et al., 2009; HOLOWKA et al., 2012; SUZUKI et al., 2012). Neste processo, a ativação da via da FLC resulta na liberação do $\mathrm{IP}_{3}$ que, ao ativar o seu receptor no retículo endoplasmático $\left(\mathrm{IP}_{3} \mathrm{R}\right)$, acarreta a liberação do cálcio estocado nessa organela e a consequente desgranulação dos mastócitos (GILFILLAN; BEAVEN, 2011). Subsequentemente, este íon é recapturado pelo retículo endoplasmático e pelas mitocôndrias, para a manutenção da homeostasia celular (BERRIDGE et al., 2003). A ativação do $\mathrm{IP}_{3} \mathrm{R}$, no retículo endoplasmático, resulta na ativação e liberação da STIM1 ("Stromal Interaction Molecule 1"), uma proteína sensora, localizada no lúmen do retículo. Esta proteína transloca-se e liga-se aos CRAC, na face interna da membrana dos mastócitos, pré-ativando estes canais. A diminuição do cálcio citoplasmático, que ocorre pela captura do mesmo pelo retículo endoplasmático, libera dímeros de STIM1, do retículo, que se ligam à STIM1, anteriormente associada aos CRAC, ativando estes canais e permitindo a entrada do cálcio do meio extracelular (DI CAPITE et al., 2011; MA; BEAVEN, 2011). Dados da literatura demonstraram que os CRAC também podem ser ativados de modo independente da liberação do cálcio do retículo e este mecanismo foi dependente da ativação prévia dos receptores de cálcio do tipo L (LTCC, do inglês "L-type calcium channel") (SUZUKI et al., 2012; YOSHIMARU et al., 2009). Com base nestas informações e nos resultados obtidos no presente estudo, podemos sugerir que o cálcio intracelular, proveniente do retículo endoplasmático, seja o responsável pela ativação dos CRAC, já que a inibição do $\mathrm{IP}_{3} \mathrm{R}$ reduziu, de modo expressivo, a desgranulação dos mastócitos ativados pela MT-I. 
Ainda, as proteínas SNAREs e VAMPs, como mencionado na introdução, quando ativadas pelo cálcio, se dimerizam e acarretam a fusão dos grânulos citoplasmáticos, com a membrana celular, com a consequente exocitose (BLANK et al., 2002; LORENTZ et al., 2012; WOSKA; GILLESPIE, 2012). Considerando estas informações e a relevância do cálcio intracelular para o efeito da MT-I, é possível sugerir que essas proteínas contribuam para o processo de desgranulação dos mastócitos sob a ação da MT-I. Contudo, são necessários estudos adicionais a este respeito.

A desgranulação dos mastócitos é um dos eventos de ativação mais intensamente estudados e esta ativação pode resultar, ou não, na síntese e liberação de mediadores recém sintetizados, como as prostaglandinas. No presente estudo, verificamos que a MT-I induziu a síntese e a liberação da prostaglandina $\mathrm{E}_{2}\left(\mathrm{PGE}_{2}\right)$, na $3^{\mathrm{a}}$ hora de estímulo. Existem poucos estudos na literatura que relatam os mecanismos de síntese da $\mathrm{PGE}_{2}$ por mastócitos e seus efeitos biológicos e autócrinos. Em apoio aos nossos dados, já foi relatado que os mastócitos da linhagem RBL-2H3 são capazes de sintetizar e liberar PGE 2 (LEE et al., 2006; NAKATANI et al., 2002; SUBRA et al., 2010).

A $\mathrm{PGE}_{2}$ pode apresentar efeitos inflamatórios ou anti-inflamatórios, dependendo do receptor ao qual ela se liga. São reconhecidos 4 subtipos de receptores para a $\mathrm{PGE}_{2}$, denominados de EP1 a EP4. De modo geral, quando este mediador lipídico liga-se aos receptores EP1 e EP3, presentes nos mastócitos, ocorre uma modulação positiva da ativação dessas células, decorrente do aumento do cálcio intracelular. Já a ativação dos receptores EP2 e EP4 modula negativamente a ativação dos mastócitos, pelo aumento da adenosina 3',5'monofosfato cíclico (AMPc) (CHUNG et al., 2005; TORRES et al., 2015). Como não foram encontradas, na literatura, informações sobre a expressão dos receptores de $\mathrm{PGE}_{2}$, em mastócitos da linhagem RBL, não é possível inferir qual seria o papel autócrino deste mediador lipídico, na presente condição experimental. Embora a expressão e a densidade dos diferentes subtipos de receptores de $\mathrm{PGE}_{2}$ varie entre as linhagens de mastócitos, as evidencias da literatura apontam a predominância da expressão de EP2 e EP3, na maioria das linhagens estudadas (TORRES et al., 2015). Neste sentido, diversos trabalhos relatam que a ligação da $\mathrm{PGE}_{2}$ aos receptores EP2 e EP4, expressos em mastócitos, induzem uma imunomodulação negativa nestas células, inibindo a liberação de histamina e leucotrienos (TORRES-ATENCIO et al., 2014). Por outro lado, a ligação da $\mathrm{PGE}_{2}$ aos receptores EP3, de mastócitos, pode induzir ou potencializar a desgranulação dessas células e causar a ativação da síntese de IL-6 (DIAZ et al., 2002; MORIMOTO et al., 2014; NGUYEN et al., 2002). Com base nestas informações, pode-se sugerir que os mastócitos da linhagem RBL, apresentem 
receptores EP3, que podem contribuir para o aumento da desgranulação destas células, sob a ação da MT-I, na $3^{\mathrm{a}}$ e $6^{\mathrm{a}}$ hora de estimulação. Neste contexto, os dados da literatura que demonstraram que a ativação dos receptores EP3 resulta na síntese de IL-6, associados aos resultados do presente estudo que demostraram a capacidade da MT-I causar um aumento dos transcritos para esta citocina, corroboram a hipótese apresentada acima. Ainda, estes resultados evidenciam que a MT-I ativa diferentes eventos nos mastócitos, relacionados à liberação de mediadores lipídicos e que a via biossintética das ciclooxigenases (COXs) é recrutada/ativada por esta fosfolipase $\mathrm{A}_{2}$.

Além dos mediadores lipídicos, os mastócitos ativados podem sintetizar diversas citocinas. Assim, no presente estudo, foi demonstrado que a MT-I causou um aumento de transcritos para citocinas de perfil Th1 e Th2. Dentre os genes de citocinas de perfil Th1, houve um aumento para o TNF- $\alpha$ e a IL-6, mas não para a IL-1 $\beta$. Dentre os de resposta Th2, houve um aumento expressivo dos transcritos para IL-4 e IL-5, além da IL-13. Os mastócitos são células versáteis e os mediadores sintetizados e liberados por elas podem ativardiversos tipos de respostas, em diferentes contextos biológicos, atuando na amplificação ou supressão de respostas imunológicas inatas ou adquiridas (CHAN et al., 2012; FROSSI et al., 2010; GALLI et al., 2011; GILFILLAN; BEAVEN, 2011; METZ; MAURER, 2007). As citocinas podem apresentar efeitos distintos, contudo, os genes de resposta Th1, escolhidos para o presente estudo (TNF- $\alpha$, IL-1 $\beta$ e IL-6), de modo geral, induzem um quadro de perfil inflamatório, com a liberação de citocinas de mesmo perfil e o recrutamento e ativação de neutrófilos e macrófagos (DAWICKI et al., 2010; KUNDER et al., 2009; PRODEUS et al., 1997; SHELBURNE et al., 2009; SUTHERLAND et al., 2008). Além disso, a IL-6 contribui para a polarização da resposta Th17, caracterizada pela liberação de IL-17, uma potente citocina inflamatória,que pode resultar no desenvolvimento de doenças autoimunes inflamatórias (NAKAE et al., 2007; PASARE; MEDZHITOV, 2003; PICONESE et al., 2009; VALZASINA et al., 2005). A liberação de citocinas de perfil Th1 por FLA 2 de veneno ofídico já foi relatada em estudos anteriores do nosso laboratório, que demonstraram que sPLA $_{2} \mathrm{~s}$ do veneno de $B$. asper, homólogas à MT-I, causaram a liberação "in vivo" de IL-1, IL-6 e TNF- $\alpha$ (ZULIANI et al., 2005). Estes autores não determinaram o tipo celular responsável pela liberação destas citocinas. Com base nos resultados obtidos no presente estudo, podemos sugerir que os mastócitos estejam envolvidos nestes efeitos.

Com relação aos genes relacionados às citocinas de perfil $\mathrm{Th} 2$, escolhidas para $\mathrm{o}$ presente estudo (IL-4, IL-5 e IL-13), vale considerar a sua importância como elementos centrais em respostas imunológicas de perfil Th2, como a alergia e a infecção por helmintos 
(ABRAHAM; JOHN, 2010; KATO, 2015; KETAVARAPU et al., 2008). Ainda, a IL-4 e a IL-13 podem induzir, indiretamente, um perfil anti-inflamatório por estimularem a polarização de macrófagos para o fenótipo M2, que é imunosupressor. Curiosamente, apesar das fosfolipases $\mathrm{A}_{2}$ de serpentes serem reconhecidas como estímulos inflamatórios, no presente estudo, a MT-I induziu um aumento mais expressivo de genes de resposta Th2, do que de genes de resposta Th1. É possível que esta resposta represente um mecanismo de modulação das ações das citocinas inflamatórias liberadas pela MT-I. Esta hipótese, contudo, necessita de estudos adicionais detalhados.Estes resultados evidenciaram, pela primeira vez, que uma sFLA $_{2}$ de serpente induz ativação gênica em mastócitos. Porém, arepercussão biológica desta ativação gênica deve ser objeto de pesquisas futuras.

Como mencionado na introdução, a análise ultraestrutural dos mastócitos contribui, de modo importante, para a compreensão dos mecanismos de ativação e desgranulação destas células, na vigência de ação de agentes ativadores. No presente estudo, foi possível verificar que a MT-I causou invaginações de membrana e um aumento significativo do número de vesículas granulares, contendo material heterogêneo. A identificação do conteúdo intraganular não foi objeto deste estudo, mas pode-se sugerir que parte deste conteúdo seja formada por constituintes celulares degradados ou alterados pela MT-I, que podem ser degradados pelas enzimas lissossomais dos mastócitos. Uma importante evidência que corrobora esta hipótese é o aumento de regiões da membrana com deposição de clatrina e a formação de pequenas vesículas revestidas com clatrina. Esta proteína contribui, de modo importante, para a internalização e degradação de diversos receptores de membrana e para o processo de fagocitose (KIRCHHAUSEN et al., 2014; MCMAHON; BOUCROT, 2011). A clatrina é uma proteína encontrada no citoplasma, que é recrutada para a membrana celular, por moléculas adaptadoras ativadas e associadas aos componentes que serão endocitados. Nesta condição, a clatrina se dimeriza, formando uma estrutura vesicular, que envolve os constituintes da membrana a serem endocitados e internaliza os mesmos, formando uma vesícula (revestida pela clatrina), que se funde a um endossomo inicial. Neste processo, os receptores endocitados pela clatrina podem se dissociar do ligante e serem transportados de volta para a membrana ou serem degrados pelos lisossomos. Este processo é importante para a reciclagem de receptores de membrana, mas também pode contribuir para eventos de transdução de sinal (DI FIORE; DE CAMILLI, 2001; MCPHERSON et al., 2001; LE ROY; WRANA, 2005; SORKIN; VON ZASTROW, 2002). Em mastócitos da linhagem RBL, a clatrina é responsável pela endocitose de vários receptores e é extremamente relevante para a internalização e degradação dos complexos FcદRI/IgE ativados pela ligação cruzada com o 
antígeno (MAO et al., 1991; MOLFETTA et al., 2005; PULLAR et al., 1996; SANTINI et al., 2000). Adicionalmente, a literatura demonstra que as vesículas revestidas por clatrina, podem conter diversos lipídeos de membrana, destinados à degradação/metabolização pelos mastócitos (CLEYRAT et al., 2013). Os dados ora obtidos não permitem concluir sobre a finalidade ou repercussão do aumento da endocitose-dependente de clatrina, induzida pela MT-I, porém, é possível sugerir que, na presente condição experimental, esta sFLA 2 tenha modificado constituintes lipídicos da membrana celular e/ou interagido com receptores na membrana e, que ambos, sejam endocitados pelos mastócitos, para posterior degradação e/ou metabolização e/ou ativação de aceptores intracelulares. Não existem dados na literatura relacionados à ação estimulatória de $\mathrm{sFLA}_{2} \mathrm{~S}$, do grupo IIA, em processos de endocitose em mastócitos. Estudos adicionais são necessários para compreender melhor este processo de endocitose, ativado pela MT-I.

Considerando que as $\mathrm{sFLA}_{2}$ constituem cerca de $45 \%$ do veneno da B. asper (VBa) e que estas toxinas são consideradas elementos importantes para a ação desteveneno (LOMONTE et al., 2014), analisamos o efeito de concentrações não citotóxicas do VBa em mastócitos e verificamos que este veneno, já na menor concentração testada $(0,5 \mu \mathrm{g} / \mathrm{mL})$, causou a desgranulação dos mastócitos, com a mesma intensidade da MT-I (0,35 $\mu \mathrm{M})$. Não surpreende o fato das concentrações do VBa, que induziram a desgranulação, serem bem menores do que as da MT-I, uma vez que os venenos botrópicos são misturas complexas de enzimas proteolíticas e lipolíticas, que podem agir de modo sinérgico, para a desgranulação dos mastócitos. Em apoio aos dados do presente estudo, relatos da literatura demonstraram a capacidade dos venenos de Bothrops atrox e B. lanceolatus desgranularem mastócitos peritoneais de rato (DE SOUZA et al., 2012; GUIMARÃES et al., 2004). Além destes venenos, demonstramos, anteriormente, que o veneno da serpente $B$. moojeni causa a desgranulação de mastócitos "in vivo" e que a histamina, liberada por esta ação, é o principal mediador responsável pelo edema de pata causado pelo veneno (GALVÃO NASCIMENTO et al., 2010). Deste modo, os resultados obtidos no presente estudo demonstram, pela primeira vez, que o veneno da serpente $B$. asper é capaz de causar a desgranulação dos mastócitos por uma ação direta sobre estas células. Além disso, estes dados sugerem, fortemente, que as sFLA $_{2}$ deste veneno, como a MT-I, sejam componentes importantes para a indução da desgranulação dos mastócitos.

Tomados em conjunto, os dados obtidos no presente estudo mostraram que a MT-I, em concentrações não citotóxicas, causa a desgranulação de mastócitos da linhagem RBL2H3. Este efeito foi parcialmente dependente da atividade catalítica da MT-I e dependente das 
fosfolipases $A_{2}$ citosólica, fosfolipase $C$ e $D$, mas não da fosfolipase $A_{2}$ independente de cálcio. Ainda, a proteína sinalizadora PI3K está envolvida no efeito da MT-I, enquanto a ERK1/2, a p38 ${ }^{\mathrm{MAPK}}$, a PKC, a MEK, a Junk e as proteínas $\mathrm{G}_{\alpha \mathrm{i}}$ e $\mathrm{G}_{\alpha \mathrm{q}}$ não contribuem para esse efeito. Além disso, o cálcio intracelular, proveniente do retículo endoplasmático, e o extracelular, via ativação dos receptores CRAC e LTCC, contribuem para a desgranulação dos mastócitos induzida pela MT-I. Além da desgranulação, a MT-I ativou outras funções importantes dos mastócitos, como a síntese e liberação de $\mathrm{PGE}_{2}$, a ativação de genes de citocinas de resposta Th1 e Th2, aumento do número de vesículas citoplasmáticas e da endocitose dependente de clatrina. Ainda, o veneno total da serpente $B$. asper foi capaz de induzir, por ação direta, a desgranulação dos mastócitos, sugerindo que MT-I seja um componente importante para este efeito do veneno total.

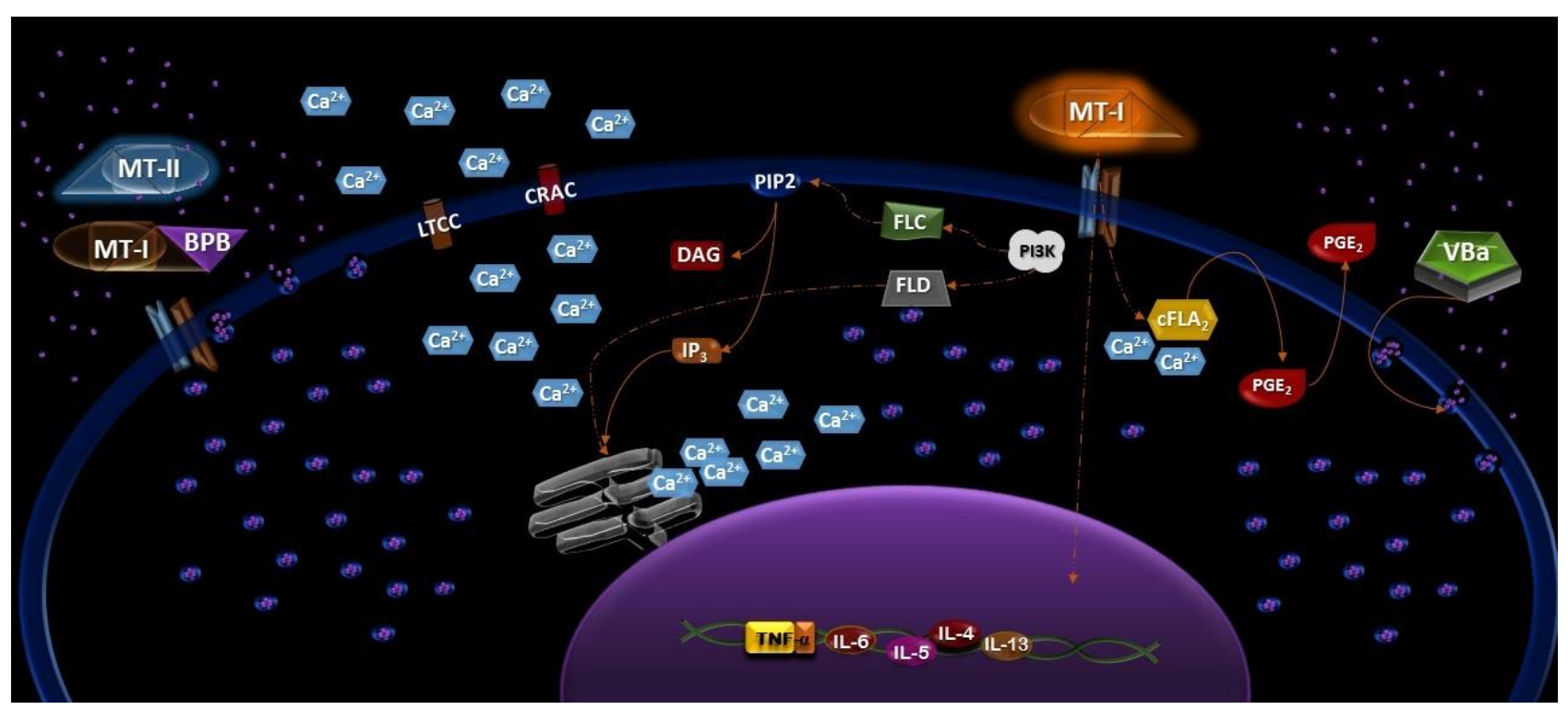

Figura 21. Representação esquemática dos mecanismos de ação da MT-I na desgranulação dos mastócitos RBL-2H3 (Desenvolvido por: MSc. Eduardo Osório Frare, 2015).

Finalmente, os resultados obtidos neste estudo, devem contribuir para o entendimento dos mecanismos de ação de $\mathrm{sFLA}_{2} \mathrm{~s}$, do grupo IIA, em doenças relacionadas à ativação dos mastócitos e para o melhor conhecimento da fisiopatologia da ação local dos venenos botrópicos. Neste sentido, este estudo aponta os mastócitos como células relevantes para o efeito local grave, característico do envenenamento botrópico e a necessidade de avaliar outros aspectos da biologia destas células, além da desgranulação dos mediadores estocados. 


\section{CONCLUSÃO}

$\checkmark$ A MT-Icausa a desgranulação de mastócitos da linhagem RBL-2H3 e este efeito é:

- parcialmente dependente da atividade catalítica da MT-I e dependente da proteínaPI3K e dasfosfolipases $\mathrm{A}_{2}$ citosólica, C e D e do cálcio intra e extracelular;

- independente das proteínas ERK1/2, p38 ${ }^{\mathrm{MAPK}}$, PKC, MEK, Junk, dafosfolipase $\mathrm{A}_{2}$ independente de cálcio e das proteínas $\mathrm{G}_{\alpha \mathrm{i}}$ e $\mathrm{G}_{\alpha \mathrm{q}}$;

$\checkmark$ Ainda, a MT-I ativa outras funções nos mastócitos, como:

-a síntese e liberação de $\mathrm{PGE}_{2}$;

- a ativação de genes de citocinas de resposta Th1 e Th2;

- o aumento do número de vesículas citoplasmáticas e da endocitose dependente de clatrina; 


\section{REFERÊNCIAS*}

ABRAHAM, S. N.; AROCK, M. Mast cells and basophils in innate immunity.Semin.Immunol., v. 10, n. 5, p. 373-381, 1998.

ABRAHAM, S. N.; MALAVIYA, R. Mast cells in infection and immunity.Infect.Immun., v. 65, n. 9, p. 3501-3508, 1997.

ABRAHAM, S. N.; ST JOHN, A. L. Mast cell-orchestrated immunity to pathogens.Nat. Rev. Immunol., v. 10, n. 6, p. 440-452, 2010.

AJUEBOR, M. N.; DAS, A. M.; VIRÁG, L.; FLOWER, R. J.; SZABÓ, C.; PERRETTI, M.Role of resident peritoneal macrophages and mast cells in chemokine production and neutrophil migration in acute inflammation: evidence for an inhibitory loop involving endogenous IL-10.J. Immunol., v. 162, n. 3, p. 1685-1691, 1999.

AJUEBOR, M. N.; FLOWER, R. J.; HANNON, R.; CHRISTIE, M.; BOWERS, K.; VERITY, A.; PERRETTI, M. Endogenous monocyte chemoattractant protein-1 recruits monocytes in the zymosan peritonitis model. J. Leukoc. Biol., v. 63, n. 1, p. 108-116, 1998.

ALAPE-GIRÓN, A.; FLORES-DÍAZ, M.; SANZ, L.; MADRIGAL, M.; ESCOLANO, J.; SASA, M.; CALVETE, J. J. Studies on the venom proteome of Bothrops asper: perspectives and applications. Toxicon, v. 54, n. 7, p. 938-948, 2009.

ALI, K.; BILANCIO, A.; THOMAS, M.; PEARCE, W.; GILFILLAN, A. M.; TKACZYK, C.; KUEHN, N.; GRAY, A.; GIDDINGS, J.; PESKETT, E.; FOX, R.; BRUCE, I.; WALKER, C.; SAWYER, C.; OKKENHAUG, K.; FINAN, P.; VANHAESEBROECK, B. Essential role for the p110delta phosphoinositide 3-kinase in the allergic response. Nature, v. 431, n. 7011, p. 1007-1011, 2004.

ARINOBU, Y.; IWASAKI, H.; AKASHI, K. Origin of basophils and mast cells.Allergol.Int., v. 58, n. 1, p. 21-28, 2009.

ARINOBU, Y.; IWASAKI, H.; GURISH, M. F.; MIZUNO, S.; SHIGEMATSU, H.; OZAWA, H.; TENEN, D. G.; AUSTEN, K. F.; AKASHI, K. Developmental checkpoints of the basophil/mast cell lineages in adult murine hematopoiesis. Proc. Natl. Acad. Sci U. S. A., v. 102, n. 50, p. 18105-18110, 2005.

ASHMOLE, I.; BRADDING, P. Ion channels regulating mast cell biology.Clin.Exp. Allergy, v. 43, n. 5, p. 491-502, 2013.

AUNG, G.; NIYONSABA, F.; USHIO, H.; KAJIWARA, N.; SAITO, H.; IKEDA, S.; OGAWA, H.; OKUMURA, K.Catestatin, a neuroendocrine antimicrobial peptide, induces human mast cell migration, degranulation and production of cytokines and chemokines. Immunology, v. 132, n. 4, p. 527-539, 2011.

"De acordo com: ASSOCIAÇÃO BRASILEIRA DE NORMAS TÉCNICAS. NBR 6023: informação e documentação: referências: elaboração. Rio de Janeiro, 2002. 
AZOUZ, N. P.; HAMMEL, I.; SAGI-EISENBERG, R. Characterization of mast cell secretory granules and their cell biology.DNA Cell Biol., v. 33, n. 10, p. 647-651, 2014.

BALSINDE, J.; BALBOA, M. A.; INSEL, P. A.; DENNIS, E. A. Regulation and inhibition of phospholipase A2.Annu. Rev. Pharmacol. Toxicol., v. 39, p. 175-189, 1999.

BALSINDE, J.; BIANCO, I. D.; ACKERMANN, E. J.; CONDE-FRIEBOES, K.; DENNIS, E. A. Inhibition of calcium-independent phospholipase A2 prevents arachidonic acid incorporation and phospholipid remodeling in P388D1 macrophages. Proc. Natl. Acad. Sci. U. S. A., v. 92, n. 18, p. 8527-8531, 1995.

BARKER, S. A.; CALDWELL, K. K.; PFEIFFER, J. R.; WILSON, B. S. Wortmanninsensitive phosphorylation, translocation, and activation of PLCgamma1, but not PLCgamma2, in antigen-stimulated RBL-2H3 mast cells. Mol. Biol. Cell, v. 9, n. 2, p. 483-496, 1998.

BARSUMIAN, E. L.; ISERSKY, C.; PETRINO, M. G.; SIRAGANIAN, R. P. IgE-induced histamine release from rat basophilic leukemia cell lines: isolation of releasing and nonreleasing clones. Eur. J. Immunol., v. 11, n. 4, p. 317-323, 1981.

BASCIAN, L. K.; BERENSTEIN, E. H.; KMAK, L.; SIRAGANIAN R. P. Monoclonal antibodies that inhibit IgE binding. J. Biol. Chem., v. 5, n. 261, p. 11823-11831, 1986.

BAZAA, A.; LUIS, J.; SRAIRI-ABID, N.; KALLECH-ZIRI, O.; KESSENTINI-ZOUARI, R.; DEFILLES, C.; LISSITZKY, J. C.; EL AYEB, M.; MARRAKCHI, N. MVL-PLA2, a phospholipase A2 from Macrovipera lebetina transmediterranea venom, inhibits tumor cells adhesion and migration. Matrix Biol., v. 28, n. 4, p. 188-193, 2009.

BENOIST, C.; MATHIS, D. Mast cells in autoimmune disease.Nature, v. 420, n. 6917, p. 875-878, 2002.

BERRIDGE, M. J.; BOOTMAN, M. D.; RODERICK, H. L. Calcium signalling: dynamics, homeostasis and remodelling. Nat. Rev. Mol. Cell. Biol., v. 4, n. 7, p. 517-529, 2003.

BLANK, U.; CYPRIEN, B.; MARTIN-VERDEAUX, S.; PAUMET, F.; POMBO, I.; RIVERA, J.; ROA, M.; VARIN-BLANK, N. SNAREs and associated regulators in the control of exocytosis in the RBL-2H3 mast cell line. Mol. Immunol., v. 38, n. 16-18, p. 1341-1345, 2002.

BLANK, U.; VARIN-BLANK, N. The RBL cell line: an experimental model system for fundamental and pharmacological studies in mast cells. Revue Francaise d'Allergologie et d'Immunologie Clinique, v. 44, n. 1, p. 51-56, 2004.

BRADDING, P.; FEATHER, I. H.; WILSON, S.; BARDIN, P. G.; HEUSSER, C. H.; HOLGATE, S. T.; HOWARTH, P. H. Immunolocalization of cytokines in the nasal mucosa of normal and perennial rhinitic subjects. The mast cell as a source of IL-4, IL-5, and IL-6 in human allergic mucosal inflammation.J. Immunol., v. 151, n. 7, p. 3853-3865, 1993.

BROWN, W, J.; CHAMBERS, K.; DOODY, A. Phospholipase A2 (PLA2) enzymes in membrane trafficking: mediators of membrane shape and function. Traffic, v. 4, n. 4, p. 214221, 2003. 
BUTRÓN, E.; GHELESTAM, M.; GUTIÉRREZ, J. M. Effects on cultured mammalian cells of myotoxin III, a phospholipase A2 isolated from Bothrops asper (terciopelo) venom.Biochim.Biophys.Acta. v. 24, n. 1179, p. 253-259, 1993.

CALDERON, L.; LOMONTE, B. Immunochemical characterization and role in toxic activities of region 115-129 of myotoxin II, a Lys49 phospholipase A2 from Bothrops asper snake venom.Arch. Biochem. Biophys., v. 358, n. 2, p. 343-350, 1998.

CALVETE, J. J. Proteomic tools against the neglected pathology of snake bite envenoming. Expert.Rev. Proteomics, v. 8, n. 6, p. 739-758, 2011.

CALVETE, J. J.; JUÁREZ, P.; SANZ, L. Snake venomics.Strategy and applications.J. Mass Spectrom., v. 42, n. 11, p. 1405-1414, 2007.

CALVETE, J. J.;SANZ, L.; ANGULO, Y.; LOMONTE, B.; GUTIÉRREZ, J. M. Venoms, venomics, antivenomics. FEBS Lett., v. 583, n. 11, p. 1736-1743, 2009.

CHAHDI, A.;FRAUNDORFER, P. F.; BEAVEN, M. A. Compound 48/80 activates mast cell phospholipase D via heterotrimeric GTP-binding proteins. J. Pharmacol Exp. Ther., v. 292, n. 1, p. 122-130, 2000.

CHAHDI, A.; SOROKIN, A.; DUNN, M. J.; LANDRY, Y.The Rac/Cdc42 guanine nucleotide exchange factor beta1Pix enhances mastoparan-activated Gi-dependent pathway in mast cells. Biochem.Biophys.Res. Commun., v. 317, n. 2, p. 384-389, 2004.

CHAN, C. Y.;ST JOHN, A. L.; ABRAHAM, S. N. Plasticity in mast cell responses during bacterial infections. Curr.Opin.Microbiol., v. 15, n. 1, p. 78-84, 2012.

CHANG, E. Y.; SZALLASI, Z.; ACS, P.; RAIZADA, V.; WOLFE, P. C.; FEWTRELL, C.; BLUMBERG, P. M.; RIVERA, J. Functional effects of overexpression of protein kinase Calpha, -beta, -delta, -epsilon, and -eta in the mast cell line RBL-2H3. J. Immunol., v. 159, n. 6, p. 2624-2632, 1997.

CHAVES, F.;BARBOZA, M.; GUTIÉRREZ, J. M. Pharmacological study of edema induced by venom of the snake Bothrops asper (terciopelo) in mice.Toxicon, v. 33, n. 1, p. 31-39, 1995.

CHEN, C. C.;GRIMBALDESTON, M, A.; TSAI, M.; WEISSMAN, I. L.; GALLI, S. J.Identification of mast cell progenitors in adult mice. Proc. Natl. Acad. Sci. U. S. A., v. 102, n. 32, p. 11408-11413, 2005.

CHILTON, F. H.; AVERILL, F. J.; HUBBARD, W. C.; FONTEH, A. N.; TRIGGIANI, M.; LIU, M. C.Antigen-induced generation of lyso-phospholipids in human airways. J. Exp. Med., v. 183, n. 5, p. 2235-2245, 1996.

CHO, S. H.; AVERILL, F. J.; HUBBARD, W. C.; FONTEH, A. N.; TRIGGIANI, M.; LIU, M. C. Protein kinase Cdelta functions downstream of $\mathrm{Ca} 2+$ mobilization in FcepsilonRI signaling to degranulation in mast cells. J. Allergy Clin. Immunol., v. 114, n. 5, p. 10851092, 2004. 
CHUNG, K. F. Evaluation of selective prostaglandin E2 (PGE2) receptor agonists as therapeutic agents for the treatment of asthma. Sci. STKE., v. 2005, n. 303, p. pe47, 2005.

CHURCH, M. K.; LEVI-SCHAFFER, F.The human mast cell.J. Allergy Clin. Immunol., v. 99, n. 2, p. 155-160, 1997.

CINTRA-FRANCISCHINELLI, M.; PIZZO, P.; ANGULO, Y.; GUTIÉRREZ, J. M.; MONTECUCCO, C.; LOMONTE, B. The C-terminal region of a Lys49 myotoxin mediates Ca2+ influx in C2C12 myotubes. Toxicon, v. 55, n. 2-3, p. 590-596, 2010.

CISSEL, D. S.; FRAUNDORFER, P. F.; BEAVEN, M. A. Thapsigargin-induced secretion is dependent on activation of a cholera toxin-sensitive and phosphatidylinositol-3-kinaseregulated phospholipase D in a mast cell line. J. Pharmacol. Exp. Ther., v. 285, n. 1, p. 110118, 1998.

CLEYRAT, C.;DAREHSHOURI, A.; ANDERSON, K. L.; PAGE, C.; LIDKE, D. S.; VOLKMANN, N.; HANEIN, D.; WILSON, B. S. The architectural relationship of components controlling mast cell endocytosis.J. Cell. Sci., v. 126, n. Pt 21, p. 4913-4925, 2013.

COCKCROFT, S.;WAY, G.; O'LUANAIGH, N.; PARDO, R.; SARRI, E.; FENSOME, A. Signalling role for ARF and phospholipase $\mathrm{D}$ in mast cell exocytosis stimulated by crosslinking of the high affinity FcepsilonR1 receptor. Mol. Immunol., v. 38, n. 16-18, p. 1277-1282, 2002.

COHEN, R.;TORRES, A.; MA, H. T.; HOLOWKA, D.; BAIRD, B. Ca2+ waves initiate antigen-stimulated Ca2+ responses in mast cells. J. Immunol., v. 183, n. 10, p. 6478-6488, 2009.

COUTTS, S. M.;NEHRING, R. E. JR.; JARIWALA, N. U.Purification of rat peritoneal mast cells: occupation of IgE-receptors by IgE prevents loss of the receptors. J. Immunol., v. 124, n. 5, p. 2309-2315, 1980.

CRIVELlATO, E.;BELTRAMI, C. A.; MALLARDI, F.; RIBATTI, D.The mast cell: an active participant or an innocent bystander? Histol.Histopathol., v. 19, n. 1, p. 259-270, 2004.

DA SILVA, E. Z.;JAMUR, M. C.; OLIVER, C.Mast cell function: a new vision of an old cell. J. Histochem. Cytochem., v. 62, n. 10, p. 698-738, 2014.

DAHLIN, J. S.;DING, Z.; HALLGREN, J.Distinguishing mast cell progenitors from mature mast cells in mice. Stem Cells Dev., v. 6, p. 6, 2015.

DAHLIN, J. S.;HEYMAN, B.; HALLGREN, J.Committed mast cell progenitors in mouse blood differ in maturity between Th1 and Th2 strains. Allergy, v. 68, n. 10, p. 1333-1337, 2013. 
DAVEY, A. M.;WALVICK, R. P.; LIU, Y.; HEIKAL, A. A.; SHEETS, E. D. Membrane order and molecular dynamics associated with $\operatorname{IgE}$ receptor cross-linking in mast cells. Biophys.J., v. 92, n. 1, p. 343-355, 2007.

DAVIDSON, F. F.; DENNIS, E. A. Evolutionary relationships and implications for the regulation of phospholipase A2 from snake venom to human secreted forms.J. Mol. Evol., v. 31, n. 3, p. 228-238, 1990.

DAWICKI, W.;JAWDAT, D. W.; XU, N.; MARSHALL, J. S.Mast cells, histamine, and IL-6 regulate the selective influx of dendritic cell subsets into an inflamed lymph node. $\mathbf{J}$. Immunol., v. 184, n. 4, p. 2116-2123, 2010.

DE SOUZA, C. A.;KAYANO, A. M.; SETÚBAL, S. S.; PONTES, A. S.; FURTADO, J. L.; KWASNIEWSKI, F. H.; ZAQUEO, K. D.; SOARES, A. M.; STÁBELI, R. G.; ZULIANI, J. P. Local and systemic biochemical alterations induced by Bothrops atrox snake venom in mice. J. Venom Res., v. 3, p. 28-34, 2012.

DENNIS, E. A. Diversity of group types, regulation, and function of phospholipase A2, J. Biol. Chem., v. 269, n. 18, p. 13057-13060, 1994.

DESAI, P.; THURMOND, R. L. Histamine H(4) receptor activation enhances LPS-induced IL-6 production in mast cells via ERK and PI3K activation. Eur. J. Immunol., v. 41, n. 6, p. 1764-1773, 2011.

DETORAKI, A.;STAIANO, R. I.; GRANATA, F.; GIANNATTASIO, G.; PREVETE, N.; DE PAULIS, A.; RIBATTI, D.; GENOVESE, A.; TRIGGIANI, M.; MARONE, G. Vascular endothelial growth factors synthesized by human lung mast cells exert angiogenic effects. J. Allergy Clin. Immunol., v. 123, n. 5, p. 1142-1149, 2009.

DI CAPITE, J.; PAREKH, A. B. CRAC channels and $\mathrm{Ca} 2+$ signaling in mast cells.Immunol.Rev., v. 231, n. 1, p. 45-58, 2009.

DI CAPITE, J. L.;BATES, G. J.; PAREKH, A. B. Mast cell CRAC channel as a novel therapeutic target in allergy.Curr.Opin.Allergy Clin.Immunol., v. 11, n. 1, p. 33-38, 2011.

DI FIORE, P. P.; DE CAMILLI, P. Endocytosis and signaling.an inseparable partnership. Cell, v. 106, n. 1, p. 1-4, 2001.

DIAZ-OREIRO, C.; GUTIERREZ, J. M. Chemical modification of histidine and lysine residues of myotoxic phospholipases A2 isolated from Bothrops asper and Bothrops godmani snake venoms: effects on enzymatic and pharmacological properties. Toxicon, v. 35, n. 2, p. 241-252, 1997.

DIAZ, B. L.;FUJISHIMA, H.; KANAOKA, Y.; URADE, Y.; ARM, J. P. Regulation of prostaglandin endoperoxide synthase-2 and IL-6 expression in mouse bone marrow-derived mast cells by exogenous but not endogenous prostanoids. J. Immunol., v. 168, n. 3, p. 13971404, 2002. 
DIAZ, C.;LOMONTE, B.; ZAMUDIO, F.; GUTIÉRREZ, J. M. Purification and characterization of myotoxin IV, a phospholipase A2 variant, from Bothrops asper snake venom.Nat. Toxins, v. 3, n. 1, p. 26-31, 1995.

DIVCHEV, D.; SCHIEFFER, B. The secretory phospholipase A2 group IIA: a missing link between inflammation, activated renin-angiotensin system, and atherogenesis? Vasc. Health Risk Manag., v. 4, n. 3, p. 597-604, 2008.

DVORAK, A. M. SWAP-70 regulates c-kit-induced mast cell activation, cell-cell adhesion, and migration. J. Histochem. Cytochem., v. 53, n. 9, p. 1043-1070, 2005 a.

DVORAK, A. M. Ultrastructural studies of human basophils and mast cells. Chem. Immunol. Allergy, v. 85, p. 68-71, 2005b.

DVORAK, A. M.; DVORAK, H. F.; GALLI, S. J. Ultrastructural criteria for identification of mast cells and basophils in humans, guinea pigs, and mice. Am. Rev. Respir. Dis., v. 128, n. 2 Pt 2, p. S49-52, 1983.

DVORAK, A. M.; KISSELL, S. Granule changes of human skin mast cells characteristic of piecemeal degranulation and associated with recovery during wound healing in situ. $\mathbf{J}$. Leukoc. Biol., v. 49, n. 2, p. 197-210, 1991.

FARQUHAR, M.;SOOMETS, U.; BATES, R. L.; MARTIN, A.; LANGEL, U.; HOWL, J. Novel mastoparan analogs induce differential secretion from mast cells. Chem. Biol., v. 9, n. 1, p. 63-70, 2002.

FARSKY, S. H.;WALBER, J.; COSTA-CRUZ, M.; CURY, Y.; TEIXEIRA, C. F. Leukocyte response induced by Bothrops jararaca crude venom: in vivo and in vitro studies. Toxicon, $\mathrm{v}$. 35, n. 2, p. 185-193, 1997.

FERNANDEZ, J.;CACCIN, P.; KOSTER, G.; LOMONTE, B.; GUTIÉRREZ, J. M.; MONTECUCCO, C.; POSTLE, A. D. Muscle phospholipid hydrolysis by Bothrops asper Asp49 and Lys49 phospholipase A(2) myotoxins--distinct mechanisms of action. FEBS J., v. 280, n. 16, p. 3878-3886, 2013.

FERRY, X.;BREHIN, S.; KAMEL, R.; LANDRY, Y. G protein-dependent activation of mast cell by peptides and basic secretagogues.Peptides, v. 23, n. 8, p. 1507-1515, 2002.

FERRY, X.;EICHWALD, V.; DAEFFLER, L.; LANDRY, Y. Activation of betagamma subunits of $\mathrm{G}(\mathrm{i} 2)$ and $\mathrm{G}(\mathrm{i} 3)$ proteins by basic secretagogues induces exocytosis through phospholipase Cbeta and arachidonate release through phospholipase Cgamma in mast cells. J. Immunol., v. 167, n. 9, p. 4805-4813, 2001.

FOX, J. W.; SERRANO, S. M. Exploring snake venom proteomes: multifaceted analyses for complex toxin mixtures. Proteomics, v. 8, n. 4, p. 909-920, 2008.

FRANCIS, B.;GUTIERREZ, J. M.; LOMONTE, B.; KAISER, I. I. Myotoxin II from Bothrops asper (Terciopelo) venom is a lysine-49 phospholipase A2. Arch. Biochem. Biophys., v. 284, n. 2, p. 352-359, 1991. 
FREMONT, D. H.;ANDERSON, D. H.; WILSON, I. A.; DENNIS, E. A.; XUONG, N. H. Crystal structure of phospholipase A2 from Indian cobra reveals a trimeric association. Proc. Natl. Acad. Sci. U. S. A., v. 90, n. 1, p. 342-346, 1993.

FROSSI, B.;GRI, G.; TRIPODO, C.; PUCILLO, C. Exploring a regulatory role for mast cells: 'MCregs'? Trends Immunol., v. 31, n. 3, p. 97-102, 2010.

FUJISAWA, D.;YAMAZAKI, Y.; LOMONTE, B.; MORITA, T. Catalytically inactive phospholipase A2 homologue binds to vascular endothelial growth factor receptor-2 via a Cterminal loop region. Biochem.J., v. 411, n. 3, p. 515-522, 2008.

FUJISHIMA, H.;SANCHEZ MEJIA, R. O.; BINGHAM, C. O.; LAM, B. K.; SAPIRSTEIN, A.; BONVENTRE, J. V.; AUSTEN, K. F.; ARM, J. P. Cytosolic phospholipase A2 is essential for both the immediate and the delayed phases of eicosanoid generation in mouse bone marrow-derived mast cells. Proc. Natl. Acad. Sci. U. S. A., v. 96, n. 9, p. 4803-4807, 1999.

FUNABA, M.; IKEDA, T.; ABE, M. Degranulation in RBL-2H3 cells: regulation by calmodulin pathway. Cell.Biol. Int., v. 27, n. 10, p. 879-885, 2003.

GALLI, S. J. New insights into "the riddle of the mast cells": microenvironmental regulation of mast cell development and phenotypic heterogeneity. Lab. Invest., v. 62, n. 1, p. 5-33, 1990.

GALLI, S. J. New concepts about the mast cell.N. Engl. J. Med., v. 328, n. 4, p. 257-265, 1993.

GALLI, S. J.;BORREGAARD, N.; WYNN. T. A. Phenotypic and functional plasticity of cells of innate immunity: macrophages, mast cells and neutrophils. Nat. Immunol., v. 12, n. 11, p. 1035-1044, 2011.

GALLI, S. J.; GORDON, J. R.; WERSHIL, B. K. Cytokine production by mast cells and basophils.Curr.Opin.Immunol., v. 3, n. 6, p. 865-872, 1991.

GALLI, S. J.;KALESNIKOFF, J.; GRIMBALDESTON, M. A.; PILIPONSKY, A.M.; WILLIAMS, C. M.; TSAI, M. Mast cells as "tunable" effector and immunoregulatory cells: recent advances. Annu.Rev. Immunol., v. 23, p. 749-786, 2005.

GALLI, S. J.;MAURER, M.; LANTZ, C. S. Mast cells as sentinels of innate immunity.Curr.Opin.Immunol., v. 11, n. 1, p. 53-59, 1999.

GALLI, S. J.; NAKAE, S. Mast cells to the defense.Nat. Immunol., v. 4, n. 12, p. 1160-1162, 2003.

GALLI, S. J.; TSAI, M. Mast cells: versatile regulators of inflammation, tissue remodeling, host defense and homeostasis. J. Dermatol. Sci., v. 49, n. 1, p. 7-19, 2008.

GALVAO NASCIMENTO, N.;SAMPAIO, M. C.; AMARAL OLIVO, R.; TEIXEIRA, C. Contribution of mast cells to the oedema induced by Bothrops moojeni snake venom and a 
pharmacological assessment of the inflammatory mediators involved. Toxicon, v. 55, n. 2-3, p. 343-352, 2010.

GARCIA-FAROLDI, G.;MELO, F. R.; RÖNNBERG, E.; GRUJIC, M.; PEJLER, G. Active caspase-3 is stored within secretory compartments of viable mast cells. J. Immunol., v. 191, n. 3, p. 1445-1452, 2013.

GHABLY, J.;SALEH, H.; VYAS, H.; PEIRIS, E.; MISRA, N.; KRISHNASWAMY, G. Paul Ehrlich's mastzellen: a historical perspective of relevant developments in mast cell biology. Methods Mol. Biol., v. 1220, p. 3-10, 2015.

GIANNOTTI, K. C.;LEIGUEZ, E.; MOREIRA, V.; NASCIMENTO, N. G.; LOMONTE, B.; GUTIÉRREZ, J. M.; LOPES DE MELO, R.; TEIXEIRA, C.A Lys49 phospholipase A2, isolated from Bothrops asper snake venom, induces lipid droplet formation in macrophages which depends on distinct signaling pathways and the C-terminal region. Biomed.Res. Int., v. 2013, p.1-14, 2013.

GILFILLAN, A. M.; BEAVEN, M. A. Regulation of mast cell responses in health and disease.Crit. Rev. Immunol., v. 31, n. 6, p. 475-529, 2011.

GILFILLAN, A. M.; RIVERA, J.The tyrosine kinase network regulating mast cell activation.Immunol.Rev., v. 228, n. 1, p. 149-169, 2009.

GILFILLAN, A. M.; TKACZYK, C. Integrated signalling pathways for mast-cell activation.Nat. Rev. Immunol., v. 6, n. 3, p. 218-230, 2006.

GRIGAT, J.; SORURI, A.; FORSSMANN, U.; RIGGERT, J.; ZWIRNER, J. Chemoattraction of macrophages, T lymphocytes, and mast cells is evolutionarily conserved within the human alpha-defensin family. J. Immunol., v. 179, n. 6, p. 3958-65, 2007.

GUIMARAES, A. Q.;CRUZ-HÖFLING, M. A.; FERREIRA DE ARAÚJO, P. M.; BON, C.; LÔBO DE ARAÚJO, A. Pharmacological and histopathological characterization of Bothrops lanceolatus (Fer de lance) venom-induced edema. Inflamm.Res., v. 53, n. 7, p. 284-291, 2004.

GUO, Z.; TURNER, C.; CASTLE, D. Relocation of the t-SNARE SNAP-23 from lamellipodia-like cell surface projections regulates compound exocytosis in mast cells. Cell, v. 94, n. 4, p. 537-548, 1998.

GUTIERREZ, J. M.; CERDAS, L. Mechanism of action of myotoxins isolated from snake venoms.Rev. Biol. Trop., v. 32, n. 2, p. 213-22,1984.

GUTIERREZ, J. M.; LOMONTE, B. Phospholipases A2 myotoxins from Bothrops asper venom. In: KINI, R. M. Venom phospholipase A2, struture, funtion and mechanism.United Kigdom: Wiley, 1997. p. 321-352.

GUTIERREZ, J. M.; LOMONTE, B. Phospholipases A2: unveiling the secrets of a functionally versatile group of snake venom toxins. Toxicon, v. 62, p. 27-39, 2013. 
GUTIERREZ, J. M.;LOMONTE, B.; LEÓN, G.; ALAPE-GIRÓN, A.; FLORES-DÍAZ, M.; SANZ, L.; ANGULO, Y.; CALVETE, J. J. Snake venomics and antivenomics: Proteomic tools in the design and control of antivenoms for the treatment of snakebite envenoming. $\mathbf{J}$. Proteomics, v. 72, n. 2, p. 165-182, 2009.

GUTIERREZ, J. M.;LOMONTE， B.; LEÓN, G.; RUCAVADO, A.; CHAVES, F.; ANGULO, Y.Trends in snakebite envenomation therapy: scientific, technological and public health considerations. Curr.Pharm. Des., v. 13, n. 28, p. 2935-2950, 2007.

GUTIERREZ, J. M.; OWNBY, C. L.; ODELL, G. V. Isolation of a myotoxin from Bothrops asper venom: partial characterization and action on skeletal muscle. Toxicon, v. 22, n. 1, p. 115-28, 1984.

HAAPAMAKI, M. M.;GRÖNROOS, J. M.; NURMI, H.; SÖDERLUND, K.; PEURAVUORI, H.; ALANEN, K.; NEVALAINEN, T. J. Elevated group II phospholipase A2 mass concentration in serum and colonic mucosa in Crohn's disease. Clin.Chem. Lab. Med., v. 36, n. 10, p. 751-755, 1998.

HADLEY, G. A.; HIGGINS, J. M. Integrin alphaEbeta7: molecular features and functional significance in the immune system. Adv. Exp. Med. Biol., v. 819, p. 97-110, 2014.

HANASAKI, K.; ARITA, H. Characterization of a high affinity binding site for pancreatictype phospholipase A2 in the rat.Its cellular and tissue distribution.J. Biol. Chem., v. 267, n. 9, p. 6414-6420, 1992.

HEINRIKSON, R. L.;KRUEGER, E. T.; KEIM, P. S. Amino acid sequence of phospholipase A2-alpha from the venom of Crotalus adamanteus. A new classification of phospholipases A2 based upon structural determinants. J. Biol. Chem., v. 252, n. 14, p. 4913-4921, 1977.

HERBERT, S. P.;ODELL, A. F.; PONNAMBALAM, S.; WALKER, J. H. Activation of cytosolic phospholipase A2-\{alpha\} as a novel mechanism regulating endothelial cell cycle progression and angiogenesis. J. Biol. Chem., v. 284, n. 9, p. 5784-5796, 2009.

HEWSON, C. A.;WATSON, J. R.; LIU, W. L.; FIDOCK, M. D.A differential role for ceramide kinase in antigen/FcvarepsilonRI-mediated mast cell activation and function.Clin.Exp. Allergy, v. 41, n. 3, p. 389-398, 2011.

HIRAYAMA, T.; KAWABE, T.; MATSUSHIMA, M.; NISHIMURA, Y.; KOBE, Y.; OTA, Y.; BABA, K.; TAKAGI, K. Ghrelin and obestatin promote the allergic action in rat peritoneal mast cells as basic secretagogues. Peptides, v. 31, n. 11, p. 2109-13, 2010.

HITOMI, T.;ZHANG, J.; NICOLETTI, L. M.; GRODZKI, A. C.; JAMUR, M. C.; OLIVER C.; SIRAGANIAN, R. P. Phospholipase D1 regulates high-affinity IgE receptor-induced mast cell degranulation. Blood, v. 104, n. 13, p. 4122-4128, 2004.

HOGABOAM, C. M.;BEFUS, A. D.; WALLACE, J. L. Modulation of rat mast cell reactivity by IL-1 beta. Divergent effects on nitric oxide and platelet-activating factor release. $\mathbf{J}$. Immunol., v. 151, n. 7, p. 3767-3774, 1993. 
HOHMAN, R. J.; DRESKIN, S. C. Measuring degranulation of mast cells.In: Curr. Protoc.Immunol., n. 7, Unit 7.26, , 2001.

HOLOWKA, D.;CALLOWAY, N.; COHEN, R.; GADI, D.; LEE, J.; SMITH, N. L.; BAIRD, B. Roles for $\mathrm{ca}(2+)$ mobilization and its regulation in mast cell functions. Front. Immunol., v. 3, p. 104, 2012.

HOLOWKA, D.;GOSSE, J. A.; HAMMOND, A. T.; HAN, X.; SENGUPTA, P.; SMITH, N. L.; WAGENKNECHT-WIESNER, A.; WU, M.; YOUNG, R. M.; BAIRD, B. Lipid segregation and IgE receptor signaling: a decade of progress. Biochim.Biophys.Acta, v. 1746, n. 3, p. 252-259, 2005.

HORIGOME, K.; BULLOCK, E. D.; JOHNSON, E. M. Effects of nerve growth factor on rat peritoneal mast cells. Survival promotion and immediate-early gene induction.J. Biol. Chem., v. 269, n. 4, p. 2695-2702, 1994.

IKAWATI, Z.;WAHYUONO, S.; MAEYAMA, K. Screening of several Indonesian medicinal plants for their inhibitory effect on histamine release from RBL-2H3 cells.J. Ethnopharmacol., v. 75, n. 2-3, p. 249-256, 2001.

JAMUR, M. C.; GRODZKI, A. C.; BERENSTEIN, E. H.; HAMAWY, M. M.; SIRAGANIAN, R. P.; OLIVER, C. Identification and characterization of undifferentiated mast cells in mouse bone marrow. Blood, v. 105, n. 11, p. 4282-4289, 2005.

JENKINS, C. M.;MANCUSO, D. J.; YAN, W.; SIMS, H. F.; GIBSON, B.; GROSS, R. W.Identification, cloning, expression, and purification of three novel human calciumindependent phospholipase A2 family members possessing triacylglycerol lipase and acylglycerol transacylase activities. J. Biol. Chem., v. 279, n. 47, p. 48968-48975, 2004.

JENKINS, G. M.; FROHMAN, M. A. Phospholipase D: a lipid centric review. Cell.Mol. Life Sci., v. 62, n. 19-20, p. 2305-2316, 2005.

JOHNSON, R. G.;CARTY, S. E.; FINGERHOOD, B. J.; SCARPA, A.The internal pH of mast cell granules.FEBS Lett., v. 120, n. 1, p. 75-79, 1980.

KAGEYAMA-YAHARA, N.; BURG, K. A.; PERLMAN, D. Suppression of phospholipase Cgamma1 phosphorylation by cinnamaldehyde inhibits antigen-induced extracellular calcium influx and degranulation in mucosal mast cells. Biochem.Biophys.Res. Commun., v. 416, n. 3-4, p. 283-288, 2011.

KAISER, I.;GUTIERREZ, J. M.; PLUMMER, D.; AIRD, S. D.; ODELL, G. V.The amino acid sequence of a myotoxic phospholipase from the venom of Bothrops asper.Arch. Biochem. Biophys., v. 278, n. 2, p. 319-325, 1990.

KALESNIKOFF, J.; GALLI, S. J. New developments in mast cell biology. Nat. Immunol., v. 9, n. 11, p. 1215-1223, 2008.

KAMINSKA, B. MAPK signalling pathways as molecular targets for anti-inflammatory therapy--from molecular mechanisms to therapeutic benefits.Biochim.Biophys.Acta, v. 1754, n. 1-2, p. 253-262, 2005. 
KANASHIRO, M. M.;DE CÁSSIA, M.; ESCOCARD, R.; PETRETSKI, J. H.; PRATES, M. V.; ALVES, E. W.; MACHADO, O. L.; DA SILVA, W. D.; KIPNIS, T. L. Biochemical and biological properties of phospholipases $\mathrm{A}(2)$ from Bothrops atrox snake venom. Biochem.Pharmacol., v. 64, n. 7, p. 1179-1186, 2002.

KATO, A. Immunopathology of chronic rhinosinusitis. Allergol.Int., v. 64, n. 2, p. 121-130, 2015.

KEHRL, J. H. G-protein-coupled receptor signaling, RGS proteins, and lymphocyte function. Crit. Rev. Immunol., v. 24, n. 6, p. 409-423, 2004.

KETAVARAPU, J. M.;RODRIGUEZ, A. R.; YU, J. J.; CONG, Y.; MURTHY, A. K.; FORSTHUBER, T. G.; GUENTZEL, M. N.; KLOSE, K. E.; BERTON, M. T.; ARULANANDAM, B. P. Mast cells inhibit intramacrophage Francisella tularensis replication via contact and secreted products including IL-4. Proc. Natl. Acad. Sci. U. S. A., v. 105, n. 27, p. 9313-9318, 2008.

KIKAWADA, E.;BONVENTRE, J. V.; ARM, J. P. Group V secretory PLA2 regulates TLR2-dependent eicosanoid generation in mouse mast cells through amplification of ERK and cPLA2alpha activation. Blood, v. 110, n. 2, p. 561-567, 2007.

KIM, D. K.;FUKUDA, T.; THOMPSON, B. T.; COCKRILL, B.; HALES, C.; BONVENTRE, J. V. Bronchoalveolar lavage fluid phospholipase A2 activities are increased in human adult respiratory distress syndrome. Am. J. Physiol., v. 269, n. 1 Pt 1, p. L109-118, 1995.

KIM, M. S.;RÅDINGER, M.; GILFILLAN, A. M.The multiple roles of phosphoinositide 3kinase in mast cell biology.Trends Immunol., v. 29, n. 10, p. 493-501, 2008.

KIM, Y. J.;KIM, K. P.; HAN, S. K.; MUNOZ, N. M.; ZHU, X.; SANO, H.; LEFF, A. R.; $\mathrm{CHO}$, W.Group V phospholipase A2 induces leukotriene biosynthesis in human neutrophils through the activation of group IVA phospholipase A2, J. Biol. Chem., v. 277, n. 39, p. 36479-36488, 2002.

KINI, R. M.; EVANS, H. J.A model to explain the pharmacological effects of snake venom phospholipases A2, Toxicon, v. 27, n. 6, p. 613-635, 1989.

KIRCHHAUSEN, T.;OWEN, D.; HARRISON, S. C.Molecular structure, function, and dynamics of clathrin-mediated membrane traffic.Cold.Spring.Harb.Perspect.Biol., v. 6, n. 5, p. a016725, 2014.

KLEMM, S.; RULAND, J. Inflammatory signal transduction from the Fc epsilon RI to NFkappa B. Immunobiology, v. 211, n. 10, p. 815-820, 2006.

KRAEUTER KOPS, S.;THEOHARIDES, T. C.; CRONIN, C.T.; KASHGARIAN, M. G.; ASKENASE, P. W. Ultrastructural characteristics of rat peritoneal mast cells undergoing differential release of serotonin without histamine and without degranulation. Cell Tissue Res., v. 262, n. 3, p. 415-424, 1990. 
KRAMER, R. M.;HESSION, C.; JOHANSEN, B.; HAYES, G.; MCGRAY, P.; CHOW, E. P.; TIZARD, R.; PEPINSKY, R. B. Structure and properties of a human non-pancreatic phospholipase A2, J. Biol. Chem., v. 264, n. 10, p. 5768-5775, 1989.

KUEHN, H. S.; GILFILLAN, A. M. G protein-coupled receptors and the modification of FcepsilonRI-mediated mast cell activation. Immunol.Lett., v. 113, n. 2, p. 59-69, 2007.

KUEHN, H. S.;JUNG, M. Y.; BEAVEN, M. A.; METCALFE, D. D.; GILFILLAN, A. M. Distinct PGE2-responder and non-responder phenotypes in human mast cell populations: "all or nothing" enhancement of antigen-dependent mediator release. Immunol.Lett., v. 141, n. 1, p. 45-54, 2011.

KUNDER, C. A.;ST JOHN, A. L.; LI, G.; LEONG, K. W.; BERWIN, B.; STAATS, H. F.; ABRAHAM, S. N. Mast cell-derived particles deliver peripheral signals to remote lymph nodes. J. Exp. Med., v. 206, n. 11, p. 2455-2467, 2009.

KWON, J. H.; LEE, J. H.; KIM, K. S.; CHUNG, Y. W.; KIM, I. Y. Regulation of cytosolic phospholipase A2 phosphorylation by proteolytic cleavage of annexin A1 in activated mast cells. J. Immunol., v. 188, n. 11, p. 5665-5673, 2012.

LAEMMLI, U. K. Cleavage of structural proteins during the assembly of the head of bacteriophage T4, Nature, v. 227, n. 5259, p. 680-685, 1970.

LAFFARGUE, M.;CALVEZ, R.; FINAN, P.; TRIFILIEFF, A.; BARBIER, M.; ALTRUDA, F.; HIRSCH, E.; WYMANN, M. P. Phosphoinositide 3-kinase gamma is an essential amplifier of mast cell function. Immunity, v. 16, n. 3, p. 441-451, 2002.

LAGUNOFF, D.; RICKARD, A. Evidence for control of mast cell granule protease in situ bylow pH.Exp. Cell.Res., v. 144, n. 2, p. 353-360, 1983.

LAMBEAU, G.; ANCIAN, P.; NICOLAS, J. P.; BEIBOER, S. H.; MOINIER, D.; VERHEIJ, H.; LAZDUNSKI, M.Structural elements of secretory phospholipases A2 involved in the binding to M-type receptors. J. Biol. Chem., v. 270, n. 10, p. 5534-5540, 1995.

LAMBEAU, G.; GELB, M. H. Biochemistry and physiology of mammalian secreted phospholipases A2.Annu.Rev. Biochem., v. 77, p. 495-520, 2008.

LAMBEAU, G.; LAZDUNSKI, M. Receptors for a growing family of secreted phospholipases A2. Trends Pharmacol.Sci., v. 20, n. 4, p. 162-170, 1999.

LAMBEAU, G.; SCHMID-ALLIANA, A.; LAZDUNSKI, M.; BARHANIN, J. Identification and purification of a very high affinity binding protein for toxic phospholipases A2 in skeletal muscle.J. Biol. Chem., v. 265, n. 16, p. 9526-9532, 1990.

LANDUCCI, E. C.;CASTRO, R. C.; PEREIRA, M. F.; CINTRA, A. C.; GIGLIO, J. R.; MARANGONI, S.; OLIVEIRA, B.; CIRINO, G.; ANTUNES, E.; DE NUCCI, G. Mast cell degranulation induced by two phospholipase A2 homologues: dissociation between enzymatic and biological activities. Eur. J. Pharmacol., v. 343, n. 2-3, p. 257-263, 1998. 
LANDUCCI, E. C.;CASTRO, R. C.; TOYAMA, M.; GIGLIO, J. R.; MARANGONI, S.; DE NUCCI, G.; ANTUNES, E. Inflammatory oedema induced by the lys-49 phospholipase A(2) homologue piratoxin-i in the rat and rabbit. Effect of polyanions and p-bromophenacyl bromide.Biochem.Pharmacol., v. 59, n. 10, p. 1289-1294, 2000.

LAW, M.;MORALES, J. L.; MOTTRAM, L. F.; IYER, A.; PETERSON, B. R.; AUGUST, A.Structural requirements for the inhibition of calcium mobilization and mast cell activation by the pyrazole derivative BTP2.Int. J. Biochem. Cell.Biol., v. 43, n. 8, p. 1228-1239, 2011.

LE ROY, C.; WRANA, J. L. Clathrin- and non-clathrin-mediated endocytic regulation of cell signalling.Nat. Rev. Mol. Cell. Biol., v. 6, n. 2, p. 112-126, 2005.

LEE, J. H.;LEE, J. Y.; KANG, H. S.; JEONG, C. H.; MOON, H.; WHANG, W. K.; KIM, C. J.; SIM, S. S.The effect of acteoside on histamine release and arachidonic acid release in RBL-2H3 mast cells.Arch. Pharm. Res., v. 29, n. 6, p. 508-513, 2006.

LEIGUEZ, E.; ZULIANI, J. P.; CIANCIARULlO, A. M.; FERNANDES, C. M.; GUTIÉRREZ, J. M.; TEIXEIRA, C. A group IIA-secreted phospholipase A2 from snake venom induces lipid body formation in macrophages: the roles of intracellular phospholipases A2 and distinct signaling pathways. J. Leukoc. Biol., v. 90, n. 1, p. 155-66, 2011.

LENNARTZ, M. R. Phospholipases and phagocytosis: the role of phospholipid-derived second messengers in phagocytosis. Int. J. Biochem. Cell.Biol., v. 31, n. 3-4, p. 415-430, 1999.

LIN, M. K.;FAREWELL, V.; VADAS, P.; BOOKMAN, A. A.; KEYSTONE, E. C.; PRUZANSKI, W. Secretory phospholipase A2 as an index of disease activity in rheumatoid arthritis. Prospective double blind study of 212 patients. J. Rheumatol., v. 23, n. 7, p. 11621166, 1996.

LIN, P.; GILFILLAN, A. M.The role of calcium and protein kinase C in the IgE-dependent activation of phosphatidylcholine-specific phospholipase D in a rat mast (RBL 2H3) cell line.Eur. J. Biochem., v. 207, n. 1, p. 163-168, 1992.

LIN, P. Y.;WIGGAN, G. A.; GILFILLAN, A. M. Activation of phospholipase D in a rat mast (RBL 2H3) cell line.A possible unifying mechanism for IgE-dependent degranulation and arachidonic acid metabolite release.J. Immunol., v. 146, n. 5, p. 1609-1616, 1991.

LISBOA, F. A.;PENG, Z.; COMBS, C. A.; BEAVEN, M. A. Phospholipase D promotes lipid microdomain-associated signaling events in mast cells. J. Immunol., v. 183, n. 8, p. 51045112, 2009.

LIZANO, S.;LAMBEAU, G.; LAZDUNSKI, M. Cloning and cDNA sequence analysis of Lys(49) and Asp(49) basic phospholipase A(2) myotoxin isoforms from Bothrops asper. Int. J. Biochem. Cell.Biol., v. 33, n. 2, p. 127-132, 2001.

LOMONTE, B.;ANGULO, Y.; MORENO, E. Synthetic peptides derived from the C-terminal region of Lys49 phospholipase A2 homologues from viperidae snake venoms: biomimetic activities and potential applications. Curr.Pharm. Des., v. 16, n. 28, p. 3224-3230, 2010. 
LOMONTE, B.; FERNÁNDEZ, J.; SANZ, L.; ANGULO, Y.; SASA, M.; GUTIÉRREZ, J. M.; CALVETE, J. J. Venomous snakes of Costa Rica: biological and medical implications of their venom proteomic profiles analyzed through the strategy of snake venomics. J.Proteomics, v. 105, p. 323-39,2014.

LOMONTE, B.; GUTIERREZ, J. M.A new muscle damaging toxin, myotoxin II, from the venom of the snake Bothrops asper (terciopelo).Toxicon.v. 27, n. 7, p. 725-33, 1989.

LOMONTE, B.; GUTIERREZ, J. M. Phospholipases A2 from viperidae snake venoms: how do they induce skeletal muscle damage? Acta Chim.Slov., v. 58, n. 4, p. 647-659, 2011.

LOMONTE, B.; MORENO, E.; TARKOWSKI, A.; HANSON, L. A.; MACCARANA, M. Neutralizing interaction between heparins and myotoxin II, a lysine 49 phospholipase A2 from Bothrops asper snake venom. Identification of a heparin-binding and cytolytic toxin region by the use of synthetic peptides and molecular modeling.J. Biol. Chem., v. 269, n. 47, p. 29867-29873, 1994.

LOMONTE, B.;PIZARRO-CERDÁ, J.; ANGULO, Y.; GORVEL, J. P.; MORENO, E.Tyr->Trp-substituted peptide 115-129 of a Lys49 phospholipase $\mathrm{A}(2)$ expresses enhanced membrane-damaging activities and reproduces its in vivo myotoxic effect. Biochim.Biophys.Acta, v. 1461, n. 1, p. 19-26, 1999.

LOMONTE, B.; RANGEL, J. Snake venom Lys49 myotoxins: From phospholipases A(2) to non-enzymatic membrane disruptors. Toxicon, v. 60, n. 4, p. 520-530, 2012.

LONGLEY, J.;DUFFY, T. P.; KOHN, S. The mast cell and mast cell disease. J. Am. Acad. Dermatol., v. 32, n. 4, p. 545-561; quiz 562-544, 1995.

LORENTZ, A.;BAUMANN, A.; VITTE, J.; BLANK, U.The SNARE Machinery in Mast Cell Secretion.Front. Immunol., v. 3, p. 143, 2012.

LUNDEQUIST, A.; PEJLER, G. Biological implications of preformed mast cell mediators.Cell.Mol. Life Sci., v. 68, n. 6, p. 965-975, 2011.

MA, H. T.; BEAVEN, M. A. Regulators of $\mathrm{Ca}(2+)$ signaling in mast cells: potential targets for treatment of mast cell-related diseases? Adv. Exp. Med. Biol., v. 716, p. 62-90,2011.

MAGRO, A. J.; TAKEDA, A. A.; SOARES, A. M.; FONTES, M. R. Structure of BthA-I complexed with p-bromophenacyl bromide: possible correlations with lack of pharmacological activity. Acta Crystallogr.D. Biol. Crystallogr., v. 61, n. Pt 12, p. 16701677, 2005.

MALAVIYA, R.; GAO, Z.; THANKAVEL, K.; VAN DER MERWE, P. A.; ABRAHAM, S. $\mathrm{N}$. The mast cell tumor necrosis factor alpha response to FimH-expressing Escherichia coli is mediated by the glycosylphosphatidylinositol-anchored molecule CD48.Proc. Natl. Acad. Sci. U. S. A., v. 96, n. 14, p. 8110-8115, 1999.

MAO, S. Y.;VARIN-BLANK, N.; EDIDIN, M.; METZGER, H. Immobilization and internalization of mutated IgE receptors in transfected cells.J. Immunol., v. 146, n. 3, p. 958966, 1991. 
MARCUSSI, S.; SANT'ANA, C. D.; OLIVEIRA, C. Z.; RUEDA, A. Q.; MENALDO, D. L.; BELEBONI, R. O.; STABELI, R. G.; GIGLIO, J. R.; FONTES, M. R.; SOARES, A. M. Snake venom phospholipase A2 inhibitors: medicinal chemistry and therapeutic potential. Curr.Top.Med. Chem., v. 7, n. 8, p. 743-756, 2007.

MCMAHON, H. T.; BOUCROT, E. Molecular mechanism and physiological functions of clathrin-mediated endocytosis.Nat. Rev. Mol. Cell. Biol., v. 12, n. 8, p. 517-533, 2011.

MCPHERSON, P. S.; KAY, B. K.; HUSSAIN, N. K. Signaling on the endocytic pathway.Traffic., v. 2, n. 6, p. 375-384, 2001.

MEDZHITOV, R. Origin and physiological roles of inflammation.Nature, v. 454, n. 7203, p. 428-435, 2008.

MEKORI, Y. A.; METCALFE, D. D. Mast cells in innate immunity.Immunol.Rev., v. 173, p. 131-140, 2000.

MELENDEZ, A. J.; KHAW, A. K. Dichotomy of Ca2+ signals triggered by different phospholipid pathways in antigen stimulation of human mast cells. J. Biol. Chem., v. 277, n. 19, p. 17255-17262, 2002.

METCALFE, D. D.; BARAM, D.; MEKORI, Y. A. Mast cells.Physiol. Rev., v. 77, n. 4, p. 1033-1079, 1997.

METCALFE, D. D.; PEAVY, R. D.; GILFILLAN, A. M. Mechanisms of mast cell signaling in anaphylaxis.J. Allergy Clin. Immunol., v. 124, n. 4, p. 639-646; quiz 647-638, 2009.

METZ, M.; GRIMBALDESTON, M. A.; NAKAE, S.; PILIPONSKY, A. M.; TSAI, M.; GALLI, S. J. Differential release of mast cell mediators and the pathogenesis of inflammation. Immunol.Rev., v. 217, p. 304-328, 2007.

METZ, M.; MAURER, M. Mast cells--key effector cells in immune responses.Trends Immunol., v. 28, n. 5, p. 234-241, 2007.

METZ, M.;PILIPONSKY, A. M.; CHEN, C. C.; LAMMEL, V.; ABRINK, M.; PEJLER, G.; TSAI, M.; GALLI, S. J. Mast cells can enhance resistance to snake and honeybee venoms. Science, v. 313, n. 5786, p. 526-530, 2006.

MIGALOVICH-SHEIKHET, H.; FRIEDMAN, S.; MANKUTA, D.; LEVI-SCHAFFER, F. Novel identified receptors on mast cells. Front. Immunol., v. 3, p. 238, 2012.

MILLER, H. R.; PEMBERTON, A. D. Tissue-specific expression of mast cell granule serine proteinases and their role in inflammation in the lung and gut.Immunology, v. 105, n. 4, p. 375-390, 2002.

MOLFETTA, R.;BELLEUDI, F.; PERUZZI, G.; MORRONE, S.; LEONE, L.; DIKIC, I.; PICCOLI, M.; FRATI, L.; TORRISI, M. R.; SANTONI, A.; PAOLINI, R. CIN85 regulates the ligand-dependent endocytosis of the IgE receptor: a new molecular mechanism to dampen mast cell function. J. Immunol., v. 175, n. 7, p. 4208-4216, 2005. 
MOON, T. C.;BEFUS, A. D.; KULKA, M. Mast cell mediators: their differential release and the secretory pathways involved. Front. Immunol., v. 5, p. 569, 2014.

MOREIRA, V.; DE CASTRO SOUTO, P. C.; RAMIREZ VINOLO, M. A.; LOMONTE, B.; MARÍA GUTIÉRREZ J.; CURI, R.; TEIXEIRA, C. A catalytically-inactive snake venom Lys49 phospholipase $\mathrm{A}(2)$ homolog induces expression of cyclooxygenase-2 and production of prostaglandins through selected signaling pathways in macrophages. Eur. J. Pharmacol., v. 708, n. 1-3, p. 68-79, 2013.

MOREIRA, V.;GUTIÉRREZ, J. M.; AMARAL, R. B.; ZAMUNÉR, S. R.; TEIXEIRA, C. F.Effects of Bothrops asper snake venom on the expression of cyclooxygenases and production of prostaglandins by peritoneal leukocytes in vivo, and by isolated neutrophils and macrophages in vitro. Prostaglandins Leukot.Essent.Fatty Acids, v. 80, n. 2-3, p. 107-114, 2009.

MORIMOTO, K.; SHIRATA, N.; TAKETOMI, Y.; TSUCHIYA, S.; SEGI-NISHIDA, E.; INAZUMI, T.; KABASHIMA, K.; TANAKA, S.; MURAKAMI, M.; NARUMIYA, S.; SUGIMOTO, Y.Prostaglandin E2-EP3 signaling induces inflammatory swelling by mast cell activation. J. Immunol., v. 192, n. 3, p. 1130-1137, 2014.

MORITA, Y.; SIRAGANIAN, R. P. Inhibition of IgE-mediated histamine release from rat basophilic leukemia cells and rat mast cells by inhibitors of transmethylation. J. Immunol., v. 127, n. 4, p. 1339-44,1981.

MOSMANN, T. Rapid colorimetric assay for cellular growth and survival: application to proliferation and cytotoxicity assays. J. Immunol. Methods,v. 65, n. 1-2, p. 55-63,1983.

MOUSLI, M.;BUEB, J. L.; BRONNER, C.; ROUOT, B.; LANDRY, Y. G protein activation: a receptor-independent mode of action for cationic amphiphilic neuropeptides and venom peptides. Trends Pharmacol.Sci., v. 11, n. 9, p. 358-362, 1990.

MUKHERJEE, A. B.;MIELE, L.; PATTABIRAMAN, N. Phospholipase A2 enzymes: regulation and physiological role. Biochem.Pharmacol., v. 48, n. 1, p. 1-10, 1994.

MURAKAMI, M.; KUDO, I. Phospholipase A2.J. Biochem., v. 131, n. 3, p. 285-292, 2002.

MURAKAMI, M.; MATSUMOTO, R.; URADE, Y.; AUSTEN, K. F.; ARM, J. P. c-kit ligand mediates increased expression of cytosolic phospholipase A2, prostaglandin endoperoxide synthase-1, and hematopoietic prostaglandin D2 synthase and increased IgEdependent prostaglandin D2 generation in immature mouse mast cells. J. Biol. Chem., v. 270, n. 7, p. 3239-3246, 1995.

MURAKAMI, M.; SHIMBARA, S.; KAMBE, T.; KUWATA, H.; WINSTEAD, M. V.; TISCHFIELD, J. A.; KUDO, I. The functions of five distinct mammalian phospholipase A2S in regulating arachidonic acid release. Type IIa and type V secretory phospholipase A2S are functionally redundant and act in concert with cytosolic phospholipase A2, J. Biol. Chem., v. 273, n. 23, p. 14411-14423, 1998. 
MURAKAMI, M.; TAKETOMI, Y. Secreted phospholipase A and mast cells.Allergol.Int., v. 64 , n. 1, p. $4-10,2015$.

MURAKAMI, M.; TAKETOMI, Y.; GIRARD, C.; YAMAMOTO, K.; LAMBEAU, G. Emerging roles of secreted phospholipase A2 enzymes: Lessons from transgenic and knockout mice. Biochimie., v. 92, n. 6, p. 561-582, 2010.

MURAKAMI, M.;TAKETOMI, Y.; MIKI, Y.; SATO, H.; HIRABAYASHI, T.; YAMAMOTO, K. Recent progress in phospholipase $A(2)$ research: from cells to animals to humans. Prog.Lipid.Res., v. 50, n. 2, p. 152-192, 2011.

MURAKAMI, M.;TAKETOMI, Y.; MIKI, Y.; SATO, H.; YAMAMOTO, K.; LAMBEAU, G. Emerging roles of secreted phospholipase A2 enzymes: the 3rd edition. Biochimie., v. 107, n. Pt A, p. 105-113, 2014.

NADUR-ANDRADE, N.; DALE, C. S.; SANTOS, A. S.; SOARES, A. M.; DE LIMA, C. J.; ZAMUNER, S. R. Photobiostimulation reduces edema formation induced in mice by Lys-49 phospholipases A2 isolated from Bothrops moojeni venom. Photochem.Photobiol.Sci., v. 13, n. 11, p. 1561-1567, 2014.

NAKAE, S.; SUTO, H.; BERRY, G. J.; GALLI, S. J. Mast cell-derived TNF can promote Th17 cell-dependent neutrophil recruitment in ovalbumin-challenged OTII mice. Blood, v. 109, n. 9, p. 3640-3648, 2007.

NAKATANI, K.; ATSUMI, M.; ARAKAWA, T.; OOSAWA, K.; SHIMURA, S.; NAKAHATA, N.; OHIZUMI, Y. Inhibitions of histamine release and prostaglandin E2 synthesis by mangosteen, a Thai medicinal plant. Biol. Pharm. Bull., v. 25, n. 9, p. 11371141, 2002.

NAKATANI, N.;UOZUMI, N.; KUME, K.; MURAKAMI, M.; KUDO, I.; SHIMIZU, T. Role of cytosolic phospholipase A2 in the production of lipid mediators and histamine release in mouse bone-marrow-derived mast cells. Biochem.J., v. 352, n. Pt 2, p. 311-317, 2000.

NGUYEN, M.;SOLLE, M.; AUDOLY, L. P.; TILLEY, S. L.; STOCK, J. L.; MCNEISH, J. D.; COFFMAN, T. M.; DOMBROWICZ, D.; KOLLER, B. H. Receptors and signaling mechanisms required for prostaglandin E2-mediated regulation of mast cell degranulation and IL-6 production. J. Immunol., v. 169, n. 8, p. 4586-4593, 2002.

NIGROVIC, P. A.; LEE, D. M. Synovial mast cells: role in acute and chronic arthritis. Immunol.Rev., v. 217, p. 19-37, 2007.

NISHIZUKA, Y. Protein kinase $\mathrm{C}$ and lipid signaling for sustained cellular responses. FASEB J., v. 9, n. 7, p. 484-496, 1995.

NUNEZ, C. E.;ANGULO, Y.; LOMONTE, B. Identification of the myotoxic site of the Lys49 phospholipase A(2) from Agkistrodon piscivorus piscivorus snake venom: synthetic Cterminal peptides from Lys49, but not from Asp49 myotoxins, exert membrane-damaging activities. Toxicon, v. 39, n. 10, p. 1587-1594, 2001. 
OKA, T.; SATO, K.; HORI, M.; OZAKI, H.; KARAKI, H. Xestospongin C, a novel blocker of IP3 receptor, attenuates the increase in cytosolic calcium level and degranulation that is induced by antigen in RBL-2H3 mast cells. Br. J. Pharmacol., v. 135, n. 8, p. 1959-66, 2002.

OLIVER, C.;SAHARA, N.; KITANI, S.; ROBBINS, A. R.; MERTZ, L. M.; SIRAGANIAN, R. P. Binding of monoclonal antibody AA4 to gangliosides on rat basophilic leukemia cells produces changes similar to those seen with Fc epsilon receptor activation. J. Cell. Biol., v. 116, n. 3, p. 635-646, 1992.

OLSSON, N.;ULFGREN, A. K.; NILSSON, G. Demonstration of mast cell chemotactic activity in synovial fluid from rheumatoid patients.Ann. Rheum. Dis., v. 60, n. 3, p. 187-193, 2001.

ORTEGA, E.;SCHWEITZER-STENNER, R.; PECHT, I. Possible orientational constraints determine secretory signals induced by aggregation of IgE receptors on mast cells. EMBO J., v. 7, n. 13, p. 4101-4109, 1988.

OSKERITZIAN, C. A. Mast cell plasticity and sphingosine-1-phosphate in immunity, inflammation and cancer.Mol. Immunol., v. 63, n. 1, p. 104-112, 2015.

OTERO, R.;GUTIÉRREZ, J.; BEATRIZ MESA, M.; DUQUE, E.; RODRÍGUEZ, O.; LUIS ARANGO, J.; GÓMEZ, F.; TORO, A.; CANO, F.; MARÍA RODRÍGUEZ, L.; CARO, E.; MARTÍNEZ, J.; CORNEJO, W.; MARIANO GÓMEZ, L.; LUIS URIBE, F.; CÁRDENAS, S.; NÚÑEZ, V.; DÍAZ, A. Complications of Bothrops, Porthidium, and Bothriechis snakebites in Colombia. A clinical and epidemiological study of 39 cases attended in a university hospital. Toxicon, v. 40, n. 8, p. 1107-1114, 2002.

OTERO, R.;LEÓN, G.; GUTIÉRREZ, J. M.; ROJAS, G.; TORO, M. F.; BARONA, J.; RODRÍGUEZ, V.; DÍAZ, A.; NÚÑEZ, V.; QUINTANA, J. C.; AYALA, S.; MOSQUERA, D.; CONRADO, L. L.; FERNÁNDEZ, D.; ARROYO, Y.; PANIAGUA, C. A.; LÓPEZ, M.; OSPINA, C. E.; ALZATE, C.; FERNÁNDEZ, J.; MEZA, J. J.; SILVA, J. F.; RAMÍREZ, P.; FABRA, P. E.; RAMÍREZ, E.; CÓRDOBA, E.; ARRIETA, A. B.; WARRELL, D. A.; THEAKSTON, R. D. Efficacy and safety of two whole IgG polyvalent antivenoms, refined by caprylic acid fractionation with or without beta-propiolactone, in the treatment of Bothrops asper bites in Colombia. Trans. R. Soc. Trop. Med. Hyg., v. 100, n. 12, p. 1173-1182, 2006.

PAES LEME, A. F.;PREZOTO, B. C.; YAMASHIRO, E. T.; BERTHOLIM, L.; TASHIMA, A. K.; KLITZKE, C. F.; CAMARGO, A. C.; SERRANO, S. M.Bothrops protease A, a unique highly glycosylated serine proteinase, is a potent, specific fibrinogenolytic agent. J. Thromb. Haemost., v. 6, n. 8, p. 1363-1372, 2008.

PALOMAKI, V. A.; LAITINEN, J. T. The basic secretagogue compound 48/80 activates G proteins indirectly via stimulation of phospholipase D-lysophosphatidic acid receptor axis and 5-HT1A receptors in rat brain sections. Br. J. Pharmacol., v. 147, n. 6, p. 596-606, 2006.

PARK, D. W.;KIM, J. R.; KIM, S. Y.; SONN, J. K.; BANG, O. S.; KANG, S. S.; KIM, J. H.; BAEK, S. H. Akt as a mediator of secretory phospholipase A2 receptor-involved inducible nitric oxide synthase expression. J. Immunol., v. 170, n. 4, p. 2093-2099, 2003. 
PASARE, C.; MEDZHITOV, R. Toll pathway-dependent blockade of CD4+CD25+ T cellmediated suppression by dendritic cells. Science, v. 299, n. 5609, p. 1033-1036, 2003.

PASSANTE, E.; EHRHARDT, C.; SHERIDAN H.; FRANKISH, N. RBL-2H3 cells are an imprecise model for mast cell mediator release. Inflamm.Res., v. 58, n. 9, p. 611-618, 2009.

PASSANTE, E.; FRANKISH, N. The RBL-2H3 cell line: its provenance and suitability as a model for the mast cell. Inflamm.Res., v. 58, n. 11, p. 737-745, 2009.

PEARCE, F. L. Calcium and histamine secretion from mast cells.Prog.Med. Chem., v. 19, p. 59-109, 1982.

PICONESE, S.;GRI, G.; TRIPODO, C.; MUSIO, S.; GORZANELLI, A.; FROSSI, B.; PEDOTTI, R.; PUCILLO, C. E.; COLOMBO, M. P. Mast cells counteract regulatory T-cell suppression through interleukin-6 and OX40/OX40L axis toward Th17-cell differentiation. Blood, v. 114, n. 13, p. 2639-2648, 2009.

PIERINI, L.;HOLOWKA, D.; BAIRD, B. Fc epsilon RI-mediated association of 6-micron beads with RBL-2H3 mast cells results in exclusion of signaling proteins from the forming phagosome and abrogation of normal downstream signaling. J. Cell. Biol., v. 134, n. 6, p. 1427-39, 1996.

PREPENS, U.; JUST, I.; VON EICHEL-STREIBER, C.; AKTORIES, K. Inhibition of Fc epsilon-RI-mediated activation of rat basophilic leukemia cells by Clostridium difficile toxin B (monoglucosyltransferase). J. Biol. Chem., v. 271, n. 13, p. 7324-9, 1996.

PRODEUS, A. P.;ZHOU, X.; MAURER, M.; GALLI, S. J.; CARROLL, M. C. Impaired mast cell-dependent natural immunity in complement C3-deficient mice.Nature, v. 390, n. 6656, p. 172-175, 1997.

PULLAR, C. E., REPETTO, B.; GILFILLAN, A. M. J. Immunol., v. 157, n. 3, p. 12261232, 1996.

QUACH, N. D.; ARNOLD, R. D.; CUMMINGS, B. S. Secretory phospholipase A2 enzymes as pharmacological targets for treatment of disease. Biochem.Pharmacol., v. 90, n. 4, p. 338348, 2014.

QURESHI, R.; JAKSCHIK, B. A.The role of mast cells in thioglycollate-induced inflammation.J. Immunol., v. 141, n. 6, p. 2090-2096, 1988.

RAMONER, R.;PUTZ, T.; GANDER, H.; RAHM, A.; BARTSCH, G.; SCHABER, C.; THURNHER, M. Dendritic-cell activation by secretory phospholipase A2, Blood, v. 105, n. 9, p. 3583-3587, 2005.

RANGEL, J.;QUESADA, O.; GUTIÉRREZ, J. M.; ANGULO, Y.; LOMONTE, B. Membrane cholesterol modulates the cytolytic mechanism of myotoxin II, a Lys49 phospholipase A2 homologue from the venom of Bothrops asper. Cell Biochem.Funct., v. 29, n. 5, p. 365-370, 2011. 
RASHID, A.;SADRODDINY, E.; YE, H. T.; VRATIMOS, A.; SABBAN, S.; CAREY, E.; HELM, B. Review: Diagnostic and therapeutic applications of rat basophilic leukemia cells. Mol. Immunol., v. 52, n. 3-4, p. 224-228, 2012.

RIBATTI, D.; CRIVELLATO, E. Mast cell ontogeny: an historical overview. Immunol.Lett., v. 159, n. 1-2, p. 11-14, 2014.

RIBATTI, D.;CRIVELlATO, E.; ROCCARO, A. M.; RIA, R.; VACCA, A. Mast cell contribution to angiogenesis related to tumour progression. Clin.Exp. Allergy, v. 34, n. 11, p. 1660-1664, 2004.

RIBATTI, D.;RONCALI, L.; NICO, B.; BERTOSSI, M. Effects of exogenous heparin on the vasculogenesis of the chorioallantoic membrane.Acta Anat. (Basel), v. 130, n. 3, p. 257-263, 1987.

RIVERA, J.;CORDERO, J. R.; FURUMOTO, Y.; LUCIANO-MONTALVO, C.; GONZALEZ-ESPINOSA， C.; KOVAROVA， M.; ODOM， S.; PARRAVICINI, V. Macromolecular protein signaling complexes and mast cell responses: a view of the organization of IgE-dependent mast cell signaling. Mol. Immunol., v. 38, n. 16-18, p. 12531258, 2002.

RIVERA, J.; GILFILLAN, A. M. Molecular regulation of mast cell activation.J. Allergy Clin. Immunol., v. 117, n. 6, p. 1214-1225; quiz 1226, 2006.

RIZZO, M. T.;NGUYEN, E.; ALDO-BENSON, M.; LAMBEAU, G. Secreted phospholipase A(2) induces vascular endothelial cell migration. Blood, v. 96, n. 12, p. 3809-3815, 2000.

ROCHA, S. L.;LOMONTE， B.; NEVES-FERREIRA， A. G.; TRUGILHO, M. R.; JUNQUEIRA-DE-AZEVEDO, I. L.; HO, P. L.; DOMONT, G. B.; GUTIÉRREZ, J. M.; PERALES, J. Functional analysis of DM64, an antimyotoxic protein with immunoglobulinlike structure from Didelphis marsupialis serum. Eur. J. Biochem., v. 269, n. 24, p. 60526062, 2002.

ROTHSCHILD, A. M.; ROTHSCHILD, Z. Liberation of Pharmacologically Active Substances by Snake VenomsIn: LEE, C. Handbook of Experimental Pharmacology. 1. ed. New York: Springer-Verlag Berlin Heidelberg, 1979. p. 591-628.

ROWAN, W. C.;SMITH, J. L.; AFFLECK, K.; AMOUR, A. Targeting phosphoinositide 3kinase delta for allergic asthma.Biochem Soc Trans., v. 40, n. 1, p. 240-245, 2012.

SAEGUSA, J.;AKAKURA, N.; WU, C. Y.; HOOGLAND, C.; MA, Z.; LAM, K. S.; LIU, F. T.; TAKADA, Y. K.; TAKADA, Y.Pro-inflammatory secretory phospholipase A2 type IIA binds to integrins alphavbeta3 and alpha4beta1 and induces proliferation of monocytic cells in an integrin-dependent manner. J. Biol. Chem., v. 283, n. 38, p. 26107-26115, 2008.

SAITO, H.;KATO, A.; MATSUMOTO, K.; OKAYAMA, Y. Culture of human mast cells from peripheral blood progenitors. Nat. Protoc., v. 1, n. 4, p. 2178-2183, 2006. 
SANTINI, F.; PENN, R. B.; GAGNON, A. W.; BENOVIC, J. L.; KEEN, J. H. Observing FcepsilonRI signaling from the inside of the mast cell membrane. J. Cell. Sci., v. 113, n. Pt 13, p. 2463-2470, 2000.

SCHALOSKE, R. H.; DENNIS, E. A.The phospholipase A2 superfamily and its group numbering system.Biochim.Biophys.Acta, v. 1761, n. 11, p. 1246-1259, 2006.

SCHRODER, T.; KIVILAAKSO, E.; KINNUNEN, P. K.; LEMPINEN, M. Serum phospholipase A2 in human acute pancreatitis.Scand. J. Gastroenterol., v. 15, n. 5, p. 633636, 1980.

SCHWARTZ, L. B.; AUSTEN, K. F. Enzymes of the mast cell granule.J. Invest. Dermatol., v. 74, n. 5, p. 349-353, 1980.

SEILHAMER, J. J.; PRUZANSKI, W.; VADAS, P.; PLANT, S.; MILLER, J. A.; KLOSS, J.; JOHNSON, L. K. Cloning and recombinant expression of phospholipase A2 present in rheumatoid arthritic synovial fluid. J. Biol. Chem., v. 264, n. 10, p. 5335-5338, 1989.

SENYSHYN, J.; BAUMGARTNER, R. A.; BEAVEN, M. A. Quercetin sensitizes RBL-2H3 cells to polybasic mast cell secretagogues through increased expression of Gi GTP-binding proteins linked to a phospholipase C signaling pathway. J. Immunol., v. 160, n. 10, p. 51365144, 1998.

SHEFLER, I.;ZAVARO, O.; RAZ, T.; BARAM, D.; SAGI-EISENBERG, R. Inhibition of basic secretagogue-induced signaling in mast cells by cell permeable $G$ alpha i-derived peptides. Int. Arch. Allergy Immunol., v. 145, n. 2, p. 131-140, 2008.

SHELBURNE, C. P.;NAKANO, H.; ST JOHN, A. L.; CHAN, C.; MCLACHLAN, J. B.; GUNN, M. D.; STAATS, H. F.; ABRAHAM, S. N. Mast cells augment adaptive immunity by orchestrating dendritic cell trafficking through infected tissues. Cell Host Microbe, v. 6, n. 4, p. 331-342, 2009.

SILLIMAN, C. C.;MOORE, E. E.; ZALLEN, G.; GONZALEZ, R.; JOHNSON, J. L.; ELZI, D. J.; MENG, X.; HANASAKI, K.; ISHIZAKI, J.; ARITA, H.; AO, L.; ENGLAND, K. M.; BANERJEE, A. Presence of the M-type $\operatorname{sPLA}(2)$ receptor on neutrophils and its role in elastase release and adhesion. Am. J. Physiol. Cell Physiol., v. 283, n. 4, p. C1102-1113, 2002.

SILVEIRA E SOUZA, A. M.;MAZUCATO, V. M.; JAMUR, M. C.; OLIVER, C. Lipid rafts in mast cell biology. J. Lipids, v. 2011, id. 752906, 2011.

SIRAGANIAN, R. P. Mast cell signal transduction from the high-affinity IgE receptor.Curr.Opin.Immunol., v. 15, n. 6, p. 639-646, 2003.

SIRAGANIAN, R. P.;DE CASTRO, R. O.; BARBU, E. A.; ZHANG, J. Mast cell signaling: the role of protein tyrosine kinase Syk, its activation and screening methods for new pathway participants. FEBS Lett., v. 584, n. 24, p. 4933-4940, 2010. 
SIRAGANIAN, R. P.;KULCZYCKI, A.; MENDOZA, G.; METZGER, H. Ionophore A23187 induced histamine release from rat mast cells and rat basophil leukemia (RBL-1) cells. J. Immunol., v. 115, n. 6, p. 1599-1602, 1975.

SIX, D. A.; DENNIS, E. A. The expanding superfamily of phospholipase A(2) enzymes: classification and characterization. Biochim.Biophys.Acta, v. 1488, n. 1-2, p. 1-19, 2000.

SOARES, A. M.; GIGLIO, J. R. Chemical modifications of phospholipases A2 from snake venoms: effects on catalytic and pharmacological properties. Toxicon, v. 42, n. 8, p. 855-868, 2003.

SORKIN, A.; VON ZASTROW, M. Signal transduction and endocytosis: close encounters of many kinds. Nat. Rev. Mol. Cell. Biol., v. 3, n. 8, p. 600-614, 2002.

SRIBAR, J.; KRIZAJ, I. Secreted Phospholipases A2 - not just Enzymes.Acta Chim Slov., v. 58, n. 4, p. 678-688, 2011.

STADEL, J. M.;HOYLE, K.; NACLERIO, R. M.; ROSHAK, A.; CHILTON, F. H. Characterization of phospholipase A2 from human nasal lavage. Am. J. Respir. Cell.Mol. Biol., v. 11, n. 1, p. 108-113, 1994.

STASSEN, M.;HÜLTNER, L.; MÜLLER, C.; SCHMITT, E. Mast cells and inflammation.Arch. Immunol.Ther.Exp. (Warsz), v. 50, n. 3, p. 179-185, 2002.

STEVENS, R. L.; ADACHI, R. Protease-proteoglycan complexes of mouse and human mast cells and importance of their beta-tryptase-heparin complexes in inflammation and innate immunity.Immunol.Rev., v. 217, p. 155-167, 2007.

SUAREZ-QUIAN, C. A. The distribution of four lysosomal integral membrane proteins (LIMPs) in rat basophilic leukemia cells. Tissue Cell, v. 19, n. 4, p. 495-504, 1987.

SUBRA, C.;GRAND, D.; LAULAGNIER, K.; STELLA, A.; LAMBEAU, G.; PAILLASSE, M.; DE MEDINA, P.; MONSARRAT, B.; PERRET, B.; SILVENTE-POIROT, S.; POIROT, M.; RECORD, M. Exosomes account for vesicle-mediated transcellular transport of activatable phospholipases and prostaglandins. J. Lipid. Res., v. 51, n. 8, p. 2105-2120, 2010.

SUPAJATURA, V.; USHIO, H.; NAKAO, A.; OKUMURA, K.; RA, C.; OGAWA, H. Protective roles of mast cells against enterobacterial infection are mediated by Toll-like receptor 4, J. Immunol., v. 167, n. 4, p. 2250-2256, 2001.

SUTHERLAND, R. E.;OLSEN, J. S.; MCKINSTRY, A.; VILLALTA, S. A.; WOLTERS, P. J. Mast cell IL-6 improves survival from Klebsiella pneumonia and sepsis by enhancing neutrophil killing. J. Immunol., v. 181, n. 8, p. 5598-5605, 2008.

SUZUKI, Y.;INOUE, T.; RA, C. Endothelial nitric oxide synthase is essential for nitric oxide generation, L-type $\mathrm{Ca} 2+$ channel activation and survival in RBL-2H3 mast cells. Biochim.Biophys.Acta, v. 1803, n. 3, p. 372-385, 2010a. 
SUZUKI, Y.;INOUE, T.; RA, C. L-type Ca2+ channels: a new player in the regulation of $\mathrm{Ca} 2+$ signaling, cell activation and cell survival in immune cells. Mol. Immunol., v. 47, n. 4, p. 640-648, 2010b.

SUZUKI, Y.;INOUE, T.; RA, C. Calcium signaling in mast cells: focusing on L-type calcium channels. Adv. Exp. Med. Biol., v. 740, p. 955-77, 2012.

SUZUKI, Y.;YOSHIMARU, T.;INOUE, T.; RA, C. Ca v 1.2 L-type Ca2+ channel protects mast cells against activation-induced cell death by preventing mitochondrial integrity disruption. Mol. Immunol., v. 46, n. 11-12, p. 2370-2380, 2009.

SZOOR, A.;SZÖLLOSI, J.; VEREB, G. Rafts and the battleships of defense: the multifaceted microdomains for positive and negative signals in immune cells. Immunol.Lett., v. 130, n. 12, p. 2-12, 2010.

TAKETOMI, Y.;UENO, N.; KOJIMA, T.; SATO, H.; MURASE, R.; YAMAMOTO, K.; TANAKA, S.; SAKANAKA, M.; NAKAMURA, M.; NISHITO, Y.; KAWANA, M.; KAMBE, N.; IKEDA, K.; TAGUCHI, R.; NAKAMIZO, S.; KABASHIMA, K.; GELB, MH.; ARITA, M.; YOKOMIZO, T.; NAKAMURA, M.; WATANABE, K.; HIRAI, H.; NAKAMURA, M.; OKAYAMA, Y.; RA, C.; ARITAKE, K.; URADE, Y.; MORIMOTO, K.; SUGIMOTO, Y.; SHIMIZU, T.; NARUMIYA, S.; HARA, S.; MURAKAMI, M. Mast cell maturation is driven via a group III phospholipase A2-prostaglandin D2-DP1 receptor paracrine axis. Nat. Immunol., v. 14, n. 6, p. 554-563, 2013.

TAYLOR, C. W.;PROLE, D. L.; RAHMAN, T.Ca(2+) channels on the move. Biochemistry, v. 48, n. 51, p. 12062-12080, 2009.

TEIXEIRA, C.;CURY, Y.; MOREIRA, V.; PICOLO, G.; CHAVES, F. Inflammation induced by Bothrops asper venom. Toxicon, v. 54, n. 7, p. 988-997, 2009.

TEIXEIRA, C. F.;CURY, Y.; OGA, S.; JANCAR, S. Hyperalgesia induced by Bothrops jararaca venom in rats: role of eicosanoids and platelet activating factor (PAF). Toxicon, v. 32, n. 4, p. 419-426, 1994.

TEIXEIRA, C. F.;LANDUCCI, E. C.; ANTUNES, E.; CHACUR, M.; CURY, Y. Inflammatory effects of snake venom myotoxic phospholipases A2, Toxicon, v. 42, n. 8, p. 947-962, 2003.

THEOHARIDES, T. C.;BONDY, P. K.; TSAKALOS, N. D.; ASKENASE, P. W. Differential release of serotonin and histamine from mast cells. Nature, v. 297, n. 5863, p. 229-231, 1982.

TORRES-ATENCIO, I.;AINSUA-ENRICH, E.; DE MORA, F.; PICADO, C.; MARTÍN, M. Prostaglandin E2 prevents hyperosmolar-induced human mast cell activation through prostanoid receptors EP2 and EP4. PLoS One, v. 9, n. 10, p. e110870, 2014.

TORRES, R.;SERRA-PAGES, M.; PLAZA, J.; HERRERIAS, A.; COSTA-FARRÉ, C.; MARCO, A.; JIMÉNEZ, M.; MAURER, M.; PICADO, C.; DE MORA, F. Activation of the Prostaglandin E2 receptor EP2 prevents house dust mite-induced airway hyperresponsiveness and inflammation by restraining mast cells activity. Clin.Exp. Allergy, v. 30, n. 10, p. 12542, 2015. 
TREBIEN, H. A.; CALIXTO, J. B. Pharmacological evaluation of rat paw oedema induced by Bothrops jararaca venom.Agents Actions, v. 26, n. 3-4, p. 292-300, 1989.

TUNCEL, N.;SENER, E.; CERIT, C.; KARASU, U.; GÜRER, F.; SAHINTÜRK, V.; BAYÇU, C.; AK, D.; FILIZ, Z. Brain mast cells and therapeutic potential of vasoactive intestinal peptide in a Parkinson's disease model in rats: brain microdialysis, behavior, and microscopy. Peptides, v. 26, n. 5, p. 827-836, 2005.

UENO, N.;TAKETOMI, Y.; KOGA, K.; ATSUMI, Y.; KIKUCHI-YANOSHITA, R.; KUDO, I.; MURAKAMI, M.A negative regulator of delayed prostaglandin D2 production in mouse mast cells.Biochim.Biophys.Acta, v. 1781, n. 8, p. 415-421, 2008.

VADAS, P. Elevated plasma phospholipase A2 levels: correlation with the hemodynamic and pulmonary changes in gram-negative septic shock. J. Lab. Clin.Med., v. 104, n. 6, p. 873881, 1984.

VADAS, P.; PRUZANSKI, W. Role of secretory phospholipases A2 in the pathobiology of disease.Lab. Invest., v. 55, n. 4, p. 391-404, 1986.

VALENTIN, E.; LAMBEAU, G. What can venom phospholipases A(2) tell us about the functional diversity of mammalian secreted phospholipases $\mathrm{A}(2)$ ? Biochimie., v. 82, n. 9-10, p. $815-831,2000$.

VALES, A.;KONDO, R.; AICHBERGER, K. J.; MAYERHOFER, M.; KAINZ, B.; SPERR, W. R.; SILLABER, C.; JÄGER, U.; VALENT, P. Myeloid leukemias express a broad spectrum of VEGF receptors including neuropilin-1 (NRP-1) and NRP-2. Leuk.Lymphoma, v. 48, n. 10, p. 1997-2007, 2007.

VALIENTE, C.;MORENO, E.; SITTENFELD, A.; LOMONTE, B.; GUTIÉRREZ, J. M.An electrophoretic study on phospholipase A2 isoenzymes in the venoms of Central American crotaline snakes. Toxicon, v. 30, n. 8, p. 815-823, 1992.

VALZASINA, B.;GUIDUCCI, C.; DISLICH, H.; KILLEEN, N.; WEINBERG, A. D.; COLOMBO,M. P. Triggering of OX40 (CD134) on CD4(+)CD25+ T cells blocks their inhibitory activity: a novel regulatory role for OX40 and its comparison with GITR. Blood, v. 105, n. 7, p. 2845-2851, 2005.

VAN SCHARRENBURG, G. J.;PUIJK, W. C.; EGMOND, M. R.; VAN DER SCHAFT, P. H.; DE HAAS, G. H.; SLOTBOOM, A. J. Effects of substitution of the absolutely invariant glutamine-4 and phenylalanine-5 in bovine pancreatic phospholipase A2 on enzymatic activity and substrate binding properties. Biochemistry, v. 21, n. 6, p. 1345-1352, 1982.

VISHWANATH, B. S.;KINI, R. M.; GOWDA, T. V. Characterization of three edemainducing phospholipase A2 enzymes from habu (Trimeresurus flavoviridis) venom and their interaction with the alkaloid aristolochic acid. Toxicon, v. 25, n. 5, p. 501-515, 1987.

VOEHRINGER, D. Protective and pathological roles of mast cells and basophils. Nat. Rev. Immunol., v. 13, n. 5, p. 362-375, 2013. 
WAY, G.;O'LUANAIGH, N.; COCKCROFT, S. Activation of exocytosis by cross-linking of the IgE receptor is dependent on ADP-ribosylation factor 1-regulated phospholipase D in RBL-2H3 mast cells: evidence that the mechanism of activation is via regulation of phosphatidylinositol 4,5-bisphosphate synthesis. Biochem.J., v. 346, n. Pt 1, p. 63-70, 2000.

WEBB, N. R. Secretory phospholipase A2 enzymes in atherogenesis.Curr.Opin.Lipidol., v. 16, n. 3, p. 341-344, 2005.

WEDEMEYER, J.; TSAI, M.; GALLI, S. J. Roles of mast cells and basophils in innate and acquired immunity.Curr.Opin.Immunol., v. 12, n. 6, p. 624-631, 2000.

WEI, J. F.;WEI, X. L.; CHEN, Q. Y.; HE, S. H. Induction of inflammatory cell accumulation by TM-N49 and promutoxin, two novel phospholipase A(2). Toxicon, v. 56, n. 4, p. 580-588, 2010.

WEI, J. F.;WEI X. L.; MO, Y. Z.; HE, S. H. Induction of mast cell accumulation, histamine release and skin edema by N49 phospholipase A2. BMC Immunol., v. 10, n. 21, p. 19972007, 2009.

WEI, J. F.;WEI, X. L.; MO, Y. Z.; HE, S. H. Induction of microvascular leakage and histamine release by promutoxin, an Arg49 phospholipase A2. Toxicon, v. 55, n. 4, p. 888896, 2010.

WEI, J. F.;WEI, X. L.; MO, Y. Z.; YANG, H.; HE, S. Induction of mast-cell accumulation by promutoxin, an Arg-49 phospholipase A2. Biomed.Res. Int., v. 2013, id.206061, 2013.

WEINSTEIN, H.; SCARLATA, S.The correlation between multidomain enzymes and multiple activation mechanisms--the case of phospholipase Cbeta and its membrane interactions.Biochim.Biophys.Acta, v. 1808, n. 12, p. 2940-2947, 2011.

WEISSLER, A.;MEKORI, Y. A.; MOR, A.The role of mast cells in non-allergic inflammation.Isr. Med. Assoc. J., v. 10, n. 12, p. 843-845, 2008.

WILSON, B. S.; DEANIN, G. G.; OLIVER, J. M. Regulation of IgE receptor-mediated secretion from RBL-2H3 mast cells by GTP binding-proteins and calcium.Biochem.Biophys.Res. Commun., v. 174, n. 3, p. 1064-1069, 1991.

WONG, G. W.;ZHUO, L.; KIMATA, K.; LAM, B. K.; SATOH, N.; STEVENS, R. L. Ancient origin of mast cells. Biochem.Biophys.Res. Commun., v. 451, n. 2, p. 314-318, 2014.

WOSKA, J. R., JR.; GILLESPIE, M. E. SNARE complex-mediated degranulation in mast cells. J Cell Mol Med., v. 16, n. 4, p. 649-656, 2012.

YAMAZAKI, Y.; MATSUNAGA, Y.; NAKANO, Y.; MORITA, T. Identification of vascular endothelial growth factor receptor-binding protein in the venom of eastern cottonmouth. A new role of snake venom myotoxic Lys49-phospholipase A2, J. Biol. Chem., v. 280, n. 34, p. 29989-29992, 2005. 
YANASE, Y.; CARVOU, N.; FROHMAN, M. A.; COCKCROFT, S. Reversible bleb formation in mast cells stimulated with antigen is $\mathrm{Ca} 2+/$ calmodulin-dependent and bleb size is regulated by ARF6. Biochem. J., v. 425, n. 1, p. 179-93, 2009.

YANG, B.;YANG, C.; WANG, P.; LI, J.; HUANG, H.; JI, Q.; LIU, J.; LIU, Z. Food allergen-induced mast cell degranulation is dependent on PI3K-mediated reactive oxygen species production and upregulation of store-operated calcium channel subunits. Scand.J. Immunol., v. 78, n. 1, p. 35-43, 2013.

YANG, Y.;OH, J. M.; HEO, P.; SHIN, J. Y.; KONG, B.; SHIN, J.; LEE, J. C.; OH, J. S.; PARK, K. W.; LEE, C. H.; SHIN, Y. K.; KWEON, D.H. Polyphenols differentially inhibit degranulation of distinct subsets of vesicles in mast cells by specific interaction with granuletype-dependent SNARE complexes. Biochem.J., v. 450, n. 3, p. 537-546, 2013.

YOSHIMARU, T.; SUZUKI, Y.; INOUE, T.; RA, C. L-type Ca2+ channels in mast cells: activation by membrane depolarization and distinct roles in regulating mediator release from store-operated Ca2+ channels. Mol. Immunol., v. 46, n. 7, p. 1267-1277, 2009.

ZHANG, Y.; DU, G. Phosphatidic acid signaling regulation of Ras superfamily of small guanosine triphosphatases.Biochim.Biophys.Acta, v. 1791, n. 9, p. 850-855, 2009.

ZHAO, H.; TANG, L.; WANG, X.; ZHOU, Y.; LIN, Z. Structure of a snake venom phospholipase A2 modified by p-bromo-phenacyl-bromide. Toxicon, v. 36, n. 6, p. 875-886, 1998.

ZULIANI, J. P.; FERNANDES, C. M.; ZAMUNER, S. R.; GUTIÉRREZ, J. M.; TEIXEIRA, C. F. Inflammatory events induced by Lys-49 and Asp-49 phospholipases A2 isolated from Bothrops asper snake venom: role of catalytic activity. Toxicon, v. 45, n. 3, p. 335-346, 2005.

ZULIANI, J. P.;GUTIÉRREZ, JM.; CASAIS E SILVA, LL.; COCCUZZO SAMPAIO, S.; LOMONTE, B.; TEIXEIRA, C. F. Activation of cellular functions in macrophages by venom secretory Asp-49 and Lys-49 phospholipases A(2). Toxicon, v. 46, n. 5, p. 523-532, 2005.

ZVARITCH, E.;LAMBEAU, G.; LAZDUNSKI, M. Endocytic properties of the M-type 180kDa receptor for secretory phospholipases A2.J. Biol. Chem., v. 271, n. 1, p. 250-257, 1996. 